\title{
ARTICLE
}

\section{RESOLVING THE REMEDIAL DILEMMA: STRATEGIES OF JUDICIAL INTERVENTION IN PRISONS}

\author{
SUSAN STURM $\dagger$
}

Table of Contents

INTRODUCTION............................... 807

I. The Dynamics of Organizational Stasis in the Prison 811

A. Absence of an Internal Normative Framework Supporting

Reform ............................. 815

1. Guardians of Order and Autonomy: Guards, "Traditionalist" Administrators, and Politicians . 816

2. Paralyzed Proponents of Change: Inmates,

Treatment Staff, and Progressive Administrators 824

B. Incentive System Reinforcing the Status Quo.......... 827

C. Inadequate Information Exchange and Expertise ........ 835

D. Insufficient Power to Institutionalize Reform.......... 837

II. Judicial Intervention and Organizational Stasis ... 846

A. Courts' Institutional Potential to Unlock Organizational Stasis .............................. 846

B. A Typology of Judicial Approaches to the Remedial Process 848

1. The Deferrer ........................ 849

2. The Director $\ldots \ldots \ldots \ldots \ldots \ldots \ldots \ldots \ldots, 851$

3. The Broker .......................... 854

4. The Catalyst ...................... 856

C. Combining Judicial Approaches .............. 860

III. The Impact of the Strategies of Judicial

† Assistant Professor of Law, University of Pennsylvania Law School. I want to thank Regina Austin, Stephen Burbank, Frank Goodman, Seth Kreimer, Howard Lesnick, Leo Levin, Martha Minow, Stephen Morse, Gerry Neuman, Ed Rubin, David Rudovsky, Michael Schill, Barbara Woodhouse, and the participants in the University of Pennsylvania Ad Hoc Seminar and the Cornell Law School Legal Studies Workshops for their helpful comments and suggestions on earlier drafts of this paper. Valuable research assistance was provided by Megan Thomas, Eric Tilles, and Bernard Wexler. 
INTERVENTION ON THE FACTORS UNDERLYING

Organizational Stasis $\ldots \ldots \ldots \ldots \ldots \ldots \ldots \ldots \ldots . . \ldots 61$

A. The Court's Capacity to Institute a Competing Normative

Framework............................ 861

1. The Deferrer and the Limits of Reliance on the Existing Normative System .............. 864

2. The Director: Norm Development Without Internalization....................... 867

3. The Broker and the Limits of the Adversary Process ............................... 875

4. The Catalyst: Creating a Context for Norm Development........................ 877

B. The Court's Capacity to Create Incentives to Undertake Change ............................... 880

1. The Deferrer and the Limits of Normative Authority............................ 885

2. The Director and the Limits of Assuming Control .......................... 887

3. The Broker and the Limits of Praise and Threats 890

4. The Catalyst: Combining Internal Process With External Pressure....................... 891

C. The Court's Capacity to Foster the Development of an Information-Gathering System ................. 898

1. The Deferrer and the Limits of the Reactive Method of Information-Gathering .......... 899

2. The Director and the Hazards of Self-Monitoring 900

3. The Catalyst: Information-Gathering as an Integral Part of the Remedial Process ......... 902

D. The Court's Capacity to Empower Change Agents Within the Prison ................................ 903

1. The Deferrer: The Power Dynamic Remains Unchanged .............................. 904

2. The Director and the Limits of the Court's Administrative Power................... 905

3. The Broker: Variations on the Theme of Deference ......................... 908

4. The Catalyst: Empowerment Through Participation and Pressure .............. 909 


\section{INTRODUCTION}

During the last several decades, courts have undertaken to remedy ongoing constitutional and statutory violations in a variety of public and private institutions. Once a court determines that an institutional pattern or practice violates the law, it must face the challenge of structuring a process that will lead to the elimination of the illegal conditions or practices. Whether this judicial activity is called "ordinary" or "extraordinary," the remedial process in institutional reform litigation may lead the trial court to engage in a range of roles beyond those usually required to resolve a traditional private dispute.

Courts involved in institutional reform litigation face a serious remedial dilemma. They are constitutionally compelled to develop a remedy for conditions and practices that violate a plaintiff's rights. ${ }^{2}$ However, courts cannot rely entirely on the defendants to eliminate these unconstitutional conditions because in many instances the responsible parties either cannot or will not take the steps necessary to do so. ${ }^{3}$ At the same time, courts must depend on those with ongoing responsibility for the institution to achieve compliance with the law. Courts lack the administrative capacity to alter basic institutional practices directly and are constrained by both a limited constitutional mandate and a narrow vision of their role. ${ }^{4}$

The controversy over institutional reform litigation swirls around this remedial dilemma. The debate is often framed in terms of whether courts should be involved at all in cases requiring institu-

1 See Eisenberg \& Yeazell, The Ordinary and the Extraordinary in Institutional Litigation, 93 HaRv. L. REv. 465, 473 (1980).

2 See Brown v. Board of Educ., 349 U.S. 294, 299-300 (1955); see also Dellinger, Of Rights and Remedies: The Constitution As a Sword, 85 HARv. L. REv. 1532, 1534 (1972) (arguing in favor of courts intervening to fulfill constitutional norms); Hill, Constitutional Remedies, 69 Colum. L. Rev. 1109, 1158 (1969) ("[F]ederal and state courts, insofar as their ordinary jurisdiction and remedial authority are adequate to the occasion, are obliged to afford such remedies as are determined, ultimately by the Supreme Court, to be appropriate in implementation of the Constitution.").

3 See infra notes $133-146$ and accompanying text. It is now widely recognized that injunctions are not self-executing; a court's order to eliminate conditions that violate the Constitution rarely results in compliance with the law. The struggle for defendant's acceptance and institutionalization of constitutional and statutory norms takes place through the remedial process. See generally Fiss, The Supreme Court, 1978 Term - Foreword: The Forms of Justice, 93 HARv. L. REv. 1, 52 (1979) ("A remedy . . is an effort of the court to give meaning to a public value in practice. ... [I]t constitutes the actualization of the right."); Special Project, The Remedial Process in Institutional Reform Litigation, 78 Colum. L. Rev. 784, 789-90 (1978) (surveying the stages of the remedial process that follow the initial findings of a violation).

4 See infra notes 301-08 \& 438-50 and accompanying text. 
tional reform. ${ }^{5}$ Advocates of an expansive judicial role tend to emphasize the courts' duty to intervene in the face of serious constitutional violations, without critically assessing the various forms that intervention may take or their potential impact on the target institution or the judiciary. ${ }^{6}$ Critics emphasize the limitations of judicially managed change without addressing the failure of the responsible officials to comply with the law and the absence of any realistic alternative means to remedy ongoing constitutional and statutory violations. $^{7}$

This Article shifts the focus of the debate from whether courts should intervene to how they should structure the remedial process to avoid, or at least minimize, the negative consequences of the remedial dilemma described above. ${ }^{8}$ Several factors justify reframing the inquiry in this manner.

First, courts are already intervening, and there is every indication that they will continue to do so. ${ }^{9}$ Thus, it makes sense to assist

5 See, e.g., Chayes, The Supreme Court, 1981 Term - Foreword: Public Law Litigation and the Burger Court, 96 Harv. L. Rev. 4, 46-47 (1982) (discussing challenges to the legitimacy of courts' remedial intervention in institutional settings); Fiss, supra note 3, at 5-6 (arguing that the special judicial function of giving meaning to public values supports court intervention in structural reform cases); Fletcher, The Discretionary Constitution: Institutional Remedies and Judicial Legitimacy, 91 YALE L.J. 635, 637 (1982) (arguing that the trial court remedial discretion in institutional suits is "presumptively illegitimate" as such suits are inherently political ); $c f$. D. HorowITz, The Courts and Social Policy 19-20 (1977) (arguing that courts are ill-suited to shape social group behavior because of the attributes of adjudication and the nature of courts). But see Diver, The Judge as Political Powerbroker: Superintending Structural Change in Public Institutions, 65 VA. L. REv. 43 (1979) (exploring the process of judicial intervention and the nature of the court's role in institutional reform litigation).

6 See, e.g., O. Fiss, The Civil Rights Injunction 18, 86-90 (1978) (advocating the primacy of the injunction in civil rights cases because of its technical advantages and allocation of power enabling the success of the civil rights claim); Johnson, The Role of the Federal Courts in Institutional Litigation, 32 ALA L. REv. 271, 279 (1981) (stating that the judiciary must stand ready to intervene where government officials fail to uphold their constitutional responsibilities toward the deprived).

7 Critics argue that the hazards of expansive judicial institutional reform include: (1) persistent constitutional violations following court orders, see Brakel, Prison Reform Litigation: Has the Revolution Gone too Far?, Corrections Today, Aug. 1987, at 160,164; (2) the potential transformation and delegitimization of the judiciary, see id. at 162; (3) the usurpation of executive or legislative branch functions, see Nagel, Separation of Powers and the Scope of Federal Equitable Remedies, 30 STAN. L. REv. $661,661-64$ (1978); and (4) the limitations of the adversary process for remedial fact finding and planning, see D. Horowirz, supra note 5, at 45-51.

8 Because this Article focuses on the judicial strategies for managing the remedial process, it will not discuss at length the various arguments for and against the legitimacy of judicial intervention, which have been amply discussed in the literature. See supra sources cited in notes 5-7.

9 Courts continue to be actively involved in institutional reform litigation in a 
courts in reconciling their constitutional mandate with their institutional limitations. Second, courts involved in institutional litigation cannot avoid deciding how the remedial process will proceed. The remedy is not simply an order setting forth a fixed set of rules. It is an ongoing, dynamic process that is structured by the court and introduced to a bureaucracy situated within a larger political and social system. In the course of formulating the remedy, overseeing implementation, monitoring compliance, and enforcing its order, ${ }^{10}$ the court faces a series of strategic choices concerning its approach to intervention. ${ }^{11}$

Finally, the various judicial approaches to the remedial process have yet to be systematically identified and analyzed for their potential impact on the conduct of those whose cooperation is essential to achieving compliance with the law. Perhaps as a result, courts frequently adopt approaches that are not well-suited to resolving the dilemma inherent in formulating and implementing a remedy. They develop their role in reaction to the failures of the compliance process as they arise. ${ }^{12}$ By self-consciously defining their role in the compliance process, courts may be better equipped to develop a role that empowers institutional reform without exceeding the bounds of judicial authority. Judicial intervention that effectively addresses the remedial dilemma by accounting for how both bureaucracies and courts operate strengthens the argument for continuing judicial involvement in institutional reform litigation. ${ }^{13}$

The challenge posed by the remedial dilemma is to structure a remedial process that allows, indeed, requires necessary changes within the institution to be developed and implemented at the level where the actual power to do so effectively exists. An evaluation of

wide variety of areas, including prisons, mental institutions, housing, school desegregation, environmental remediation and union corruption. In the area of prison litigation alone, as of January 1989, there were ten jurisdictions in which the entire prison system was under court order, thirty jurisdictions in which a major institution in the state was under court order or consent decree, and eight jurisdictions with pending system-wide litigation. See Status Report: State Prisons and the Courts, Nat'l Prison Project J., Winter 1989, at 7, 10-11.

10 For a description of the various stages of the remedial process, see Special Project, supra note 3, at 788-843.

11 See infra notes $184-87$ and accompanying text.

12 See infra text accompanying notes 210, 244.

13 This is not to say that the concerns about the legitimacy of judicial intervention will be fully alleviated by defining an effective judicial role. However, one major aspect of the legitimacy critique is that courts have exceeded their capacity in institutional reform cases. Defining an effective judicial role responds to this concern. 
courts' capacity to meet this challenge necessarily begins with an analysis of the institutional context that is the object of judicial intervention. The organizational dynamics that lock in unconstitutional conditions and prevent institutional self-correction in the absence of judicial intervention, which I will refer to as the "dynamics of organizational stasis," define both the need for judicial intervention and the factors to which the court must respond to promote organizational change. The court's potential to resolve the remedial dilemma depends upon its capacity to influence the factors underlying the dynamics of organizational stasis.

This Article explores the dynamics of organizational stasis and judicial intervention in the prison. ${ }^{14}$ The discussion will focus on judicial intervention in this particular context, rather than on the development of a general theory of institutional reform litigation. A broader theory requires a greater understanding of the extent to which a particular institutional context presents special demands, limitations, and potential for judicial intervention than presently exists. The court's capacity to resolve the remedial dilemma may vary depending on such factors as the degree of acceptance and clarity of the legal norm, the nature of the organizational and political obstacles to change, whether the target institution is public or private, and the division of power among the relevant parties. Prior to evaluating the courts' role in institutional reform litigation in general, it is important to understand the factors underlying organizational stasis in a variety of institutional contexts, the parameters of judicial involvement in those contexts, and the dynamic relationship between judicial intervention and organizational change. Only then can a general theory of judicial intervention that accounts for the common elements of institutional reform litigation and the variations presented by particular institutional settings be built. This Article begins this inquiry with the prison.

Part I analyzes the dynamics of organizational stasis within the prison system, exposing the norms, incentives, information patterns, and power structure that lock in the current conditions in prisons.

14 This Article focuses on the conditions and practices in prisons-institutions incarcerating those convicted of crimes and sentenced to prison terms. Although some of the dynamics of jails, which incarcerate pre-trial detainees and misdemeanor offenders serving short sentences, will differ due to such factors as the lack of continuity of the inmate population and the multiple sources and purposes of jail incarceration, see R. GoldFarb, Jails: The Ultimate Ghetto 2-5 (1975); Garofalo \& Clark, The Inmate Subculture in Jails, 12 CRIM. JusT. \& BEHAv. 415, 417 (1985), much of the analysis that follows will apply to jails as well. 
These dynamics disable regular prison participants from achieving institutional self-correction. Part II describes the attributes that enable courts to alter the prisons' norms, incentives, information, and power so that reform can occur. Acknowledging that the court's capacity to realize its potential depends on the approach adopted to manage the compliance process, the Article identifies four characteristic judicial approaches to prison intervention: the deferrer, the director, the broker, and the catalyst.

Part III examines the capacity of each judicial management strategy to alter the dynamics of organizational stasis. The deferrer approach in most cases will perpetuate the dynamics that contribute to the extreme prison conditions warranting judicial intervention. The director, although effective in introducing discrete programs that require little organizational change, is likely to fall short of her remedial goals and may have a negative or regressive impact on the development of creative, systemic approaches to the problems facing prisons. The broker approach is likewise ill-suited to prompt significant organizational change.

This Article argues that the catalyst approach is best suited to address the dynamics of organizational stasis that lock in unconstitutional prison conditions and yet remain within the boundaries of the judicial role. The catalyst uses a deliberative, participatory process, backed by traditional judicial sanctions, to engage the necessary parties in effective confrontation of the prison problems. and foster the internal development of a new normative framework. The use of sanctions alters the incentive system in place to convince members of the corrections system that noncompliance carries substantial costs and that effective participation in the deliberative process is the only way to eliminate judicial intervention. At the same time, the process reduces the negative impact of sanctions and rewards those who assume responsibility for compliance with additional support, resources, praise, and ultimately, reduced judicial oversight.

Finally, Part IV concludes by discussing possible methods of promoting effective judicial intervention and the implications of this analysis for other institutional contexts.

\section{The Dynamics of Organizational Stasis in the Prison}

Prison reform efforts embrace a wide range of normative goals, from the elimination of large scale prisons entirely to improvement 
of their rehabilitative capacity. ${ }^{15}$ However, the normative goal of the constitutional enterprise, as currently defined by the courts, is limited, focusing on the elimination of particularly extreme deprivations and abuses that sometimes characterize imprisonment. Federal courts may intervene only after determining that either a particular practice or the totality of prison conditions constitutes cruel and unusual punishment or violates some other constitutional provision. ${ }^{16}$ Furthermore, these practices or conditions must be dramatically and unequivocally inhumane or arbitrary in order to violate the Constitution. ${ }^{17}$ Prisons under judicial decree typically subject inmates to pervasive violence, physical conditions that threaten their

15 See, e.g., R. Johnson, Hard Time: Understanding and Reforming the PRISON 4 (1987) (advocating reforms to make imprisonment a "constructively painful experience" resulting in the correction and rehabilitation of offenders); PRESIDENT's Commission on Law Enforgement and Administration of Justice, The Challenge of CRIMe in a FreE Society 13-14 (1967) (advocating greater use of communitybased facilities); Prison Research Education Action Project, Instead of Prisons: A HaNDBOoK FOR ABolitionists 7 (1976) (advocating abolition of large-scale prisons).

16 See, e.g., Rhodes v. Chapman, 452 U.S. 337, 352 (1981) (finding no cruel and unusual punishment in housing two inmates in one cell); Hutto v. Finney, 437 U.S. 678,680 (1978) (noting that the trial court had found a violation of the eighth amendment's prohibition against cruel and unusual punishment); Bounds v. Smith, 430 U.S. 817, 828 (1977) (holding fifth and fourteenth amendment right of meaningful access to courts requires prison authorities to provide law libraries or legal assistance); Estelle v. Gamble, 429 U.S. 97, 104 (1976) (concluding that deliberate indifference to medical needs constitutes cruel and unusual punishment); Wolff v. McDonnell, 418 U.S. 539, 555 (1974) (finding that the state violates the fifth and fourteenth amendment right. to due process in disciplinary procedures by revoking credits for good behavior without notice, a hearing, or due process of law); Procunier v. Martinez, 416 U.S. 396, 413-14 (1974) (finding that the first amendment restricts mail censorship); Washirgton v. Lee, 263 F. Supp. 327, 333 (M.D. Ala. 1966), (finding segregation to be a violation of the equal protection prohibition of race discrimination), aff'd per curiam, 393 U.S. 266 (1968).

17 See, e.g., Rhodes, 452 U.S. at 352 (double celling not cruel and unusual punishment); Inmates of Occoquan v. Barry, 844 F.2d 828, 837 (D.C. Cir. 1988) (eighth amendment addresses cruel, not deficient conditions); Cody v. Hillard, 830 F.2d 912, 915 (8th Cir. 1987) (conditions were "light years removed from the torture, cruel deprivation, and sadistic punishment with which the Cruel and Unusual Punishments Clause is concerned"), cert. denied, I08 S. Ct. 1078 (1988); Shrader v. White, 761 F.2d 975, 977 (4th Cir. 1985) (fear of assault must create significant mental pain for inmate violence to be unconstitutional); Delgado v. Cady, 576 F. Supp. 1446, 1451 (E.D. Wis. 1983) (overcrowding is not unconstitutional despite its extremely harsh impact on inmates). See generally M.K. Harris \& D. Spiller, After Decision: Implementation of Judicial Decrees in Correctional Settings 6-7 (1976) (documenting brutal conditions that led to court intervention in four prison and jail cases). 
health and safety, arbitrary and abusive treatment at the hands of prison officials, or some combination of these conditions. ${ }^{18}$

Conditions and practices in prisons are notoriously resistant to change despite general agreement that they are inadequate. ${ }^{19}$ Any meaningful assessment of judicial intervention directed toward changing prison conditions therefore must begin with an analysis of the factors that disable the regular participants in the prison system from eliminating these conditions without outside intervention.

In order to understand the dynamics that lock in "cruel and unusual" prison conditions, one must move beyond the image of the organization as a unitary actor rationally pursuing goals and policies established by the formal leadership. ${ }^{20}$ The prison functions as a dynamic system, consisting of both formal organizational structures and informal subgroups with particular norms, interests, and power

18 See, e.g., Ruiz v. Estelle, 679 F.2d 1115, 1140, 1150 (5th Cir. 1982) (noting the trial court's finding that "assault or molestation by fellow inmates was a continual threat," that the population density of inmates was "shocking," and that there were " 'numerous' instances of '[g]rievous neglect' " concerning inmate medical care), modified, 688 F.2d 266 (5th Cir. 1983), cert. denied, 460 U.S. 1042 (1983); Groseclose v. Dutton, 609 F. Supp. 1432, 1435, 1446 (M.D. Tenn. 1985) (noting expert testimony that death row at Tennessee State Penitentiary was one of the worst in country), vacated and remanded, 829 F.2d 581 (6th Cir. 1987); Palmigiano v. Garrahy, 443 F. Supp. 956, 979 (D.R.I. 1977) (noting that prisoner "sentenced to a regime in which he will be forced to live in a state of constant fear of violence, in imminent danger to his bodily integrity and physical and psychological well-being"), aff'd, 616 F.2d 598 (1st Cir.), cert. denied, 449 U.S. 839 (1980); Martinez Rodriguez v. Jiminez, 409 F. Supp. 582, 587, 590, 593-95 (D.P.R.) (noting that " $[\mathrm{m}]$ entally deranged inmates are placed in . . . dungeons," and that "Kangaroo' courts are held by inmates and sentences, including beatings and stabbings, are imposed"), stay denied, 537 F.2d 1 (1st Cir. 1976), aff'd, 551 F.2d 877 (1st Cir. 1977).

19 See R. Roberg \& V. Webb, Critical Issues in Corrections: Problems, Trends, and Prospects 14 (1981) [hereinafter Critical Issues in Corrections].

20 Courts sometimes assume that prison administrators can and will pursue organizational goals consistent with the constitution, and that the failure to do so is caused by guilty individuals who intentionally or negligently resist change. See, e.g., Hewitt v. Helms, 459 U.S. 460, 474 (1983) (granting wide-ranging deference to prison officials in adopting policies for order and security); Rhodes v. Chapman, 452 U.S. 337, 352 (1980) ("[C]ourts cannot assume that state legislatures and prison officials are insensitive to the requirements of the Constitution . . .."). Yet the assumption of the classical administrative model that top managers are fully responsive to public interests and, in turn, have complete policy control over their subordinates ignores the cumulative and sometimes irrational impact of the combination of rational individual decisions. See J. KNOTT \& G. MILler, Reforming Bureaucracy: The Politics of Institutional Choice 10-11, 146 (1987). In addition, this view dramatically over-simplifies the complexities of change within prison systems by failing to consider the political and organizational dynamics that influence the possibility and direction of change. Formal organizational structures and informal subgroups profoundly influence whether change will be initiated at all. See infra and supra text accompanying notes $150-177$. 
bases. The prison organization is further influenced by the political environment in which it is situated. Any attempted change in the conditions, policies, or practices is filtered through the dynamics of interaction both within and among the various participants in the prison system.

Thus, it is necessary to examine the four factors underlying the dynamics of organizational stasis in prisons: (1) norms, ${ }^{21}$ (2) incentives, ${ }^{22}$ (3) information, ${ }^{23}$ and (4) power. $^{24}$ Part I of this Article examines these factors in relation to each major group within the prison system-inmates, guards, treatment staff, and administrators-as well as the possible sources of external pressure and sup-

21 Norms establish the standards of conduct that shape the participants' views of whether change is desirable, acceptable, or unnecessary.

22 Incentives influence individuals to initiate, cooperate in, or resist change by distributing sanctions for particular behaviors. See J. KNOTT \& G. Miller, supra note 20 , at $173-75$ (" $[T]$ he structural rules operating in a given organization determine what behaviors are required of individuals who hope to 'succeed' in those organizations" and thus establish a set of incentives that shape behavior); see also A. Downs, Inside BurEaUCRACY 84-85 (1966) (asserting that the general motives of officials include money, power, prestige, convenience, security, loyalty, pride in work performance, desire to serve public interest, and commitment to a specific program of action); H. Kaufman, The Limits of Organizational Change 61-65 (1971) (discussing strategies for reducing incentives to oppose change).

23 The capacity to obtain and use information shapes the nature and effectiveness of proposed reforms. See Chin \& Benne, General Strategies for Effecting Changes in Human Systems, in The Planning of Change 22, 34-36 (W. Bennis, $K$. Benne, R. Chin \& K. Corey eds. 3d ed. 1976) (discussing the role of data, feed-back and problem solving in facilitating change); see also $\mathrm{H}$. Simon, Administrative Behavior: A Study of Decision-Making in Administrative Organization 293 (3d ed. 1976) (noting the limits of individual capacity to process information within organizations); Calvert, The Value of Biased Information: A Rational Choice Model of Political Advice, 47 J. of PoL. 530, 530 (1985) (noting that decisionmakers must rely upon advisers to distill information. for the decisionmaking process).

24 Power reflects the capacity of an individual or group to influence the behavior of those whose cooperation is necessary to accomplish the desired change. Power has been defined as the ability of A to "get B to do something B would not otherwise do." Dahl, The Concept of Power, 2 BeHav. Sci. 201, 203 (1957); see also Emerson, PowerDependence Relations, 27 AM. Soc. REv. 31,32 (1962) (expressing A's power over B as the amount of B's resistance A can overcome); 1 M. WEBER, ECONOMY AND SocIETY 53 (1968) (defining power as "the probability that one actor . . . will . . carry out his own will despite resistance”).

Power need not derive solely from the organizational position. One important source of power derives from conırol over the distribution of incentives to others within the organization. A related aspect of power is the capacity to alter the perception of others as to how the organization is functioning, through the collection and dissemination of information. Finally, power also derives from the potential to create uncertainty with respect to the capacity of various participants to perform their jobs and satisfy their needs. See M. Crozier, The Bureaucratic Phenomenon 158 (1964). 
port for change. The analysis derives from studies of bureaucracies, prisons in general, groups within the prison, and field studies of particular prisons. ${ }^{25}$ This analysis does not describe every prison or every group within the prison system. Nor is it an inexorable dynamic unaffected by the political environment in which the prison is situated. ${ }^{26}$ Rather, it illustrates patterns among inmates, guards, treatment staff, and prison administration that tend to determine the prison dynamic.

This analysis reveals that prisons, in addition to the factors that predispose "street-level bureaucracies" 27 to maintain the status quo, are particularly resistant to change in the absence of outside intervention. The normative framework of the prison system predisposes its participants to preserve the status quo. Participants in the prison system have strong disincentives to pursue change, due to the political powerlessness of inmates, the structural isolation of corrections from the community, and the lack of political consensus and support for reform. Corrections systems exhibit a profound lack of the information and expertise necessary to pursue meaningful change. Internal reformers have limited power to generate the resources and cooperation necessary to achieve change.

\section{A. Absence of an Intermal Normative Framework Supporting Reform}

Virtually unchecked pressure, generated both within the prison

25 The following works generally inform the analysis of the prison that follows: R. Cloward, D. Cressey, G. Grosser, R. McCleery, L. Ohlin, G. Sykes \& S. Messinger, Theoretical Studies in Social Organization of the Prison (Conference Group on Correctional Behavior Social Science Research Council ed. 1960) [hereinafter Theoretical Studies]; M. Crozier, supra note 24; A. Downs, supra note 22; E. Goffman, Asỵlums: Essays on the Social Situation of Mental Patients and Other Inmates (1961); M.K. Harris \& D. SPIller, supra note 17; J. Irwin, Prisons In Turmoil (1980); J. Jacobs, Stateville: The Penitentiary in Mass Society (1977); H. Kaufman, supra note 22; M. Lipsky, Street-Level Bureaucracy: Dilemmas of the Individual in Public Services (1980); L. Lombardo, Guards Imprisoned: Correctional Officers at Work (1981); C. Perrow, Complex Organizations (3d ed. 1986); G. Sykes, The Society of Captives: A Study of a Maximum Security Prison (1958).

26 Indeed, the external political environment is often a critical factor in determining the degree of internal resistance to change and the need for outside intervention to achieve meaningful reform. See M.K. HARRIS \& D. SPILLER, supra note 17 , at 83.

27 Martin Lipsky introduced this term in Street-Level Bureaucracies to describe public service organizations composed primarily of "[p]ublic service workers [streetlevel bureaucrats] who interact directly with citizens in the course of their jobs, and who have substantial discretion in the exercise of their work." M. LIPSKY, supra note 25 , at 3 . 
system and by the external political environment, channels prison resources and the attention and energy of prison staff to the task of processing inmates efficiently and avoiding visible disruption. Those in a position to define the normative agenda-the guards, "traditionalist" administrators, and political actors setting corrections policyembrace order and autonomy to the exclusion of other values. Those within the prison community who embrace the norms of providing humane treatment and maintaining public accountabilityinmates, treatment staff, and reform-minded administrators, frequently lack the status and power necessary to institutionalize those norms within the prison system.

\section{Guardians of Order and Autonomy: Guards, "Traditionalist" Administrators, and Politicians}

Guards as a group are critical to the successful implementation of prison reform policies. They are the filter through which reforms concerning treatment of inmates, programming, and service delivery must pass. ${ }^{28}$ Yet guards are the group within the prison most directly invested in the norms underlying the status quo. Orderthe absence of disruption, the smooth, predictable, controlled operation of the prison-is central to the guards' normative agenda.

Many factors shape and influence guards' preoccupation with order. Informal indoctrination ${ }^{29}$ and formal training, to the extent

28 All groups within the prison are dependent on guards for the orderly functioning of the system. Inmates are dependent on guards for goods, services, protection, and movement. Staff and professionals are dependent on guards for the delivery of inmates to their sessions and the communication of the need for services to and from inmates. Administrators are dependent on guards for the maintenance of order, the communication of new policies to the inmates, and the implementation of those policies.

29 Guards develop their approach to the job experientially. They are schooled by their peers, inmates, and immediate superiors in the existing norms of the prison; not in the formal goals or aspiralions of corrections, but in the standards and routines of day-to-day practice. Sie B. Crouch \& J. Marquart, AN Appeal to Justice: Litigated Reform of Texas Prisons 54-55 (1989). Corrections work at the guard level remains largely unprofessionalized. Although this situation has begun to change in some prison systems, sometimes in the wake of prison litigation, see, e.g., Jurik, Individual and Organizational Determinants of Correctional Officer Attitudes Toward Inmates, 23 CRIminology 523, 523-24 (1985) (describing recent efforts to recruit "degree-bearing individuals," women, and minorities and to professionalize prison workers in security positions), the quality of training and of performance of prison guards is a serious problem. The status of prison guards is low, and in some communities the job carries a stigma that discourages guards from developing a strong professional identity. See L. Lombardo, supra note 25, at 162-63. As there is little shared, generally accessible knowledge concerning corrections practice, training remains limited and largely skills oriented. See L. Carroll, Hacks, Blacks 
that guards receive any, often focus on techniques that maintain or restore order. ${ }^{30}$ The formal duties of guards revolve around surveillance and supervision designed to enforce a routine. ${ }^{31}$ Because guards bear responsibility for maintaining order, they stand to increase their power by promoting the importance of order to the institution. ${ }^{32}$ Limited resources exacerbate the tendency to choose processing over service. ${ }^{33}$ Finally, order functions as a coping mechanism that enables guards to handle the stress created by the combi-

and Cons: Race Relations in a Maximum Security Prison 47-61 (1974); L. LOMBARDo, supra note 25, at 28-37; Jacobs \& Crotty, The Guard's World, in J. JacoBs, New Perspectives on Prisons and Imprisonment 133, 135 (1983); see also Holt v. Hutto, 363 F. Supp. 194, 201 (E.D. Ark. 1973) (finding that guards recruited from small rural towns near prisons were young, poorly paid, poorly educated, poorly trained, and had little general experience), aff'd in part and rev'd in part sub nom. Finney v. Arkansas Bd. of Corrections, 505 F.2d 194 (8th Cir. 1974).

30 See L. LomBardo, supra note 25, at 34-36.

31 Traditionally, guards derived significant authority over inmates from their absolute discretion and control over the inmates' day-to-day lives. See G. Sykes, supra note 25, at 50; $c$. B. Crouch \& J. MARQUART, supra note 29 , at $62-63,66-68,75-84$ (describing the wide discretion and authority guards had over the lives of the prisoners through the official and unofficial reward and punishment system in the Texas prison system, including requiring inmates to stand with their toes and nose against the wall, threatening inmates with force or severe punishment, and using physical force). Guards could manipulate rewards, threats, punishments, and the use of force to induce compliance with the organizational routine. See, e.g., id. at 78-84 (describing three increasingly harsh types of physical coercion employed by the guards, "tune-ups" or "attitude adjustments," "ass whippings" and severe beatings, and noting the importance of such punishment and its deterrent effects as important elements of the overall control strategy).

32 Guards strive to attain the authority, discretion, and control that they perceive is necessary in order to maintain order in a system occupied by unwilling inhabitants. See L. Lombardo, supra note 25, at 52 (noting that authority of guards viewed as crucial to order maintenance role). Guards will enhance the status of inmates who have developed power over other inmates through violence in exchange for their assistance in maintaining order. See M.K. HARRIS \& D. SPILlER, supra note 17 , at 51 (describing inmates' role in maintaining order); J. IRWIN, supra note 25, at 23-24 ("[G]uards granted privileges to key prisoners in return for their support in maintaining order.").

33 See H. Kaufman, supra note 22, at 23-29; M. LIPSKY, supra note 25, at 125-28. The perceived importance of maintaining order is accentuated by the huge inmate to guard ratio, which requires the guards to respond to a large group of individuals and yet maintain order and institutional routine. See M. LIPSKY, supra note 25, at 117, 119; C. Silberman, Criminal Violence, Criminal Justice 393-95 (1978); G. Sykes, supra note 25, at 17, 21-25. Prison overcrowding exacerbates this tendency. See Ellis, Crowding and Prison Violence: Integration of Research and Theory, 11 CRIM. JUST. \& BEHAV. 277, 292-95, 301 (1984); Toch, Warehouses for People?, 478 Annals 58 (1985). Also, because the threat of disorder and resistance is ever-present in the prison, there is a tendency to treat every situation as potentially explosive, thus warranting extreme measures at the expense of the inmate. See E. Goffman, supra note 25 , at 84 . This tendency is exacerbated by the fear of personal injury that guards in a volatile system experience. 
nation of conflicting factors that typically afflict the street-level bureaucrat: wide-ranging discretion, inadequate resources and conflicting demands. ${ }^{34}$

These factors predispose guards to exhibit the phenomenon of goal displacement: order becomes the predominant institutional goal. All other institutional goals (such as service delivery, rehabilitation, and even punishmenr) are subordinated to and furthered by the pursuit of order. ${ }^{35}$ The status of the inmate is defined in relation to the goal of order, rather than in relation to an externally defined or moral norm. Responding to individual demands for service imposes costs on and threatens the smooth functioning of the system. $^{36}$ Dehumanization must be tolerated, if not celebrated, to maintain order. ${ }^{37}$

Reform poses a threat to guards' normative commitment to order, autonomy, and authority. The introduction of legal norms and the professionalization of corrections administration have limited guards' recourse to their traditional control mechanisms. ${ }^{38}$

34 See M. LiPSKY, supra note 25, at 44-45; R. MERTon, Social ThEory AND Social Structure 195-205 (1957); cf. P. Blau \& M. Meyer, Bureaucracy in Modern SOCIETY 142-45 (1987) (arguing that bureaucracies encourage strict rules and rigidity which result in increased tension when unexpected situations arise).

35 See, e.g., J. JACOBS, supra note 25, at 45-46 (demonstrating how the system of total control as the basis of order at Stateville was repackaged in terms of rehabilitation, but the practices remained the same); M. LIPSKY, supra note 25, at 44 ("The study of street-level bureaucrats may be seen as a study in goal displacement when the norm of individual client orientation becomes subordinated to the needs for mass processing.").

36 Consequently, movement of any kind is discouraged because it poses the risk of disruption. See, e.g., B. Crouch \& J. Marquart, supra note 29, at 60-61 (noting that inmate movement was strictly regimented and limited before the $1980 \mathrm{~s}$ in Texas).

37 The commitment to order provides guards with a justification for brutal punishments and harsh disciplinary measures. See J. JACOBS, supra note 25, at 41-42, 47 (describing various methods of punishment used to maintain control); Marquart, Prison Guards and the Use of Coercion as a Mechanism of Prisoner Control, 24 CRIMINology $347,355-56$ (documenting how and why guards in Texas penitentiary used physical force as routine mechanism of social control).

38 See Special Project, Judicial Intervention in Corrections: The Califormia ExperienceAn Empirical Study, 20 UCLA L. REv. 452, 493 (1973).

Some traditional methods of maintaining order and authority have been restricted by the courts. Corporal punishment is no longer embraced, at least publicly, as an appropriate mechanism of control, and has been declared illegal by the courts. See, e.g., Jackson v. Bishcip, 404 F.2d 571, 579-80 (8th Cir. 1968) (finding whipping to be cruel and unusual punishment). Guards may no longer legally impose arbitrary or summary punishment on inmates. See Wolff v. McDonnell, 418 U.S. 539, 557-58 (1974). Finally, guards may not legally prevent inmates from communicating with the outside world. See Procunier v. Martinez, 416 U.S. 396, 415 (1974) (holding that mail censorship regulations violate first amendment). But see 
Reforms often diminish guards' autonomy by intensifying supervision of their conduct. Change also disrupts the routines established by guards to maintain order. It introduces uncertainty and ambiguity to the lives of both inmates and guards-factors which guards associate with disruption and disorder. Reforms that introduce programs and services increase the movement of inmates through the prison and impose additional demands on guards to provide services and supervision. This higher level of activity increases the difficulty of maintaining order. ${ }^{39}$

Change tends to upset the power structure that guards have developed among inmates to maintain control. Guards perceive that the traditional sources of their authority and power have not been replaced. ${ }^{40}$ The introduction of new participants, programs, and objectives often circumvents the lines of authority and communication that have been under the control of guards under the old system. ${ }^{41}$ It may also affect guards' access to sources of illicit benefits derived under the old system. ${ }^{42}$

Thus, guards are more likely to embrace traditional norms and goals. Change is perceived as inconsistent with guards' overriding concern for order, authority, and autonomy. The norm of resistance to external authority develops in response to perceived attacks on guards' authority and autonomy. Indeed, guards often view reforms imposed upon them by administrators or through the judicial process to be unwise, unsound, and likely to lead to the system's collapse. ${ }^{43}$

O'Lone v. Estate of Shabazz, 482 U.S. 342, 353 (1987) (holding that regulations prohibiting correspondence between inmates at different prisons do not violate first amendment).

39 See Special Project, supra note 38 , at $493,497-501$. In order to handle the complexity of tasks or an increased level of activity, individuals often create routines to better manage their performance. See M. LIPSKx, supra note 25, at 83-86; R. MERTON, supra note 34 , at 195-205.

40 See L. Lombardo, supra note 25, at 78; Hepburn, The Prison Control Structure and its Effects on Work Attitudes: The Perceptions and Attitudes of Prison Guards, $15 \mathrm{~J}$. OF CRIM. JusT. 49, 50, 52-57 (1987) (describing surveys documenting guards' concern over loss of control and increase in inmates' power and rights).

41 See McCleery, Corrections Administration and Political Change, in Prison Wrrhin SocieTY 113, 127-29 (L. Hazelrigg ed. 1968) (describing how new patterns and lines of communication formed in the treatment unit and by-passed the monopoly of communication once enjoyed by the custodial force).

42 See id.; see also Colvin, The 1980 New Mexico Prison Riot, 29 Soc. Probs. 449, 453 (1982) (explaining that prison staff members who colluded with drug traffickers needed to protect drug rackets since disruptions might jeopardize drug connections and "bring the heat down" upon the traffickers).

43 See L. Lombardo, supra note 25, at 129-32 (documenting guards' cynical 
"Traditionalist" administrators tend to share the guards' custodial perspective and are likely to embrace the norm of order and control as the predominant institutional goal. Many have been in the criminal justice system for an extensive period and have been schooled in the norms, patterns, and practices of the existing system. ${ }^{44}$ This background predisposes traditionalist administrators to adhere to an instrumental view of the status of the inmate by defining that status in terms of the needs of the prison to maintain order, rather than in relation to service delivery or rehabilitative values. ${ }^{45}$

Consequently, "traditionalist" administrators tend to reject the notion that systemic change is either required or desired for a prison system operating under the traditional control model. Some may not see brutal or inhumane prison conditions as remediable or problematic. ${ }^{46}$ They are more likely to accept current limitations on resources as given and to work within them to maintain order and control. To the extent that they pursue reform, it is more likely to be in the direction of "returning to the good old days"-restoring order, discipline, and control.. ${ }^{47}$ Traditionalist administrators pursue status and power by attempting to preserve their position, enhance

attitude toward leadership qualities of correctional administrators and effectiveness of their programs); J. Wynne, Prison EMployee Unionism: The IMPACT of Correctional Administration and Programs 24-25, 62-63 (1978); Hepburn, supra note 40 , at 50 ("[G]uards subscribe to a normative system that stresses distrust and cynicism toward administration.").

44 See, e.g., B. Crouch \& J. Marquart, supra note 29, at 43 (describing how Jim Estelle, appointed director of Texas prisons in 1972, started as a prison guard and rose through the ranks); J. JACOBS, supra note 25, at 28-29 (noting that warden Ragen of Stateville was a former sheriff from a small rural Illinois town and had only a ninth grade education and a "provincial background"). Traditionalist administrators frequently receive little or no training in management prior to assuming the position of commissioner or warden. See Coln, The Failure of Correctional Management, in Issues in Corrections and Administration 119, 126-27 (G. Killinger, P. Cromwell \& B. Cromwell eds. 1976).

45 See, e.g., B. Crouch \& J. Marquart, supra note 29, at 40 (arguing that Beto and Ragen shared a philosophy of maintaining tight disciplinary control).

46 See, e.g., The Clement E. Vose Memorial Colloquium, The Organizational Consequences of Remedial Law: A. Working Conference 6 (R. Wood \& R. Murphy eds. Apr. 24, 1987) [hereinafter The Organizational Consequences of Remedial Law] (describing how Rhode Island administrators were oblivious to despicable conditions of the state's prison facilities and the brutality and favoritism practiced by the guards); Elvin, Oklahoma Prisoner Earns Place in History: The Story of Battle v. Anderson, 10 Nat'l Prison Project J. 1, 4-5 (1986) (discussing depositions taken from correctional personnel which candidly described prison conditions and revealed the personnel's matter of fact attitude that "[n]obody's going to interfere with us, how dare you poke your nose in here"). at 128 .

47 See B. Crouch \& J. Marquart, supra note 29, at 44; McCleery, supra note 41 , 
their autonomy and authority within the prison, and maintain and expand the prison bureaucracy. ${ }^{48}$

Unlike traditionalist administrators, professional managers often come from outside the corrections hierarchy and bring to the prison system a set of values they developed through professional training. ${ }^{49}$ These values may conflict to some extent with the prisons' status quo. As their training is usually in management or business, professional managers tend to consider efficiency and conflict management to be the keys to redressing the problems afflicting the prison. ${ }^{50}$ Professional managers may not have a coherent, welldeveloped philosophy of corrections, and they are more likely to think of themselves as "keepers" hired to ensure that inmates are kept in, kept alive, and serviced efficiently within the existing resource limitations. ${ }^{51}$ Their managerial focus shapes their value structure and priorities. They are explicitly committed to order, centralization, and efficiency, and they may not view it as their job to develop norms apart from the bureaucratic imperative.

These professional managers believe that the prison must be changed because it is inefficient, not because it is brutal. ${ }^{52}$ Inmates must be accommodated to the extent necessary to achieve compliance and order. Guards remain the keystone to attaining the organizational goal-order. Guards' power and autonomy, however, must be routinized, rationalized, and subjected to central control. ${ }^{53}$ Managers will attempt to run the institution according to rules and

48 See, e.g., J. JACOBS, supra note 25, at 28 (stating that Ragen developed a system of control by gaining a large measure of economic, political and moral autonomy).

49 See, e.g., id. at 73-104 (describing the emergence of a professional administration); see also Letter from Tennessee Governor Lamar Alexander to State Representative Michael D. Murphy (April 12, 1985) (announcing appointment of new Commissioner of Correction with background as manager and planner in areas other than corrections, whose strength is "planning and management").

50 See J. JACOBS, supra note 25 , at 75.

51 See, e.g., id. at 103-04 (describing how professional manager brought to prison a commitment to scientific management rather than to any correctional ideology); see also L. YackLe, Reform and Regret: The Story of Federal Judicial Involvement in the Alabama Prison System 56 (1989) (explaining that the hospital was understaffed due to a lack of funding and that the staff was "doing the best that could be expected under the circumstances"); Alexander, The New Prison Administrators and the Court: New Directions in Prison Law, 56 TEx. L. Rev. 963, 967-71 (1978) (arguing that new administrators adapted inmate protections to existing bureaucratic functioning of organization, changing practices only when necessary to smooth bureaucratic procedures and functions).

52 See, e.g., J. JACOBS, supra note 25, at 91 (stating that administrator abolished isolation, arguing that "throwing six inmates into a cramped cell, where it was likely that one or more would be beaten and raped, was not sound prison management").

53 See, e.g., id. at 88 ("'Stateville] must develop tables of organization, lines of 
tightly-defined procedures, responding only to normative constraints imposed from the outside. ${ }^{54}$

Professional managers do not challenge the prison's normative commitment to order. They have no normative or moral agenda aimed at restoring the prisoners' dignity. Rather, the inmates' status is important to the manager only to the extent that it directly affects the efficient operation of the prison. Managers are thus reluctant to undertake any major change, given its potentially disruptive influence, unless such a change is legally required or will contribute to the orderly processing of inmates. ${ }^{55}$

The political system frequently reinforces values and norms that perpetuate the status quo. Society lacks a political consensus about the goals, purposes, and legitimacy of imprisonment. ${ }^{56}$ Prisons today must fulfill a series of conflicting goals, and the political system cannot or will not provide a clear message as to what constitutes acceptable conditions and practices within the prison. ${ }^{57}$ In the face

authority and accountability. It must meet deadlines of all sorts imposed by [the central office]. Most important, it must adhere to the Administrative Regulations.").

54 See, e.g., id. at 103-04 (revealing that the "primary commitment is to running a safe, clean, program-oriented institution which functions smoothly on a day-to-day basis and that is not in violation of code provisions, Administrative Regulations, or court orders").

55 See, e.g., id. at 91 ("[The] main emphasis was upon building a modern organization."); see also Alexander, supra note 51, at 967-71 (explaining how managers "neutralize" external requirements in order to maintain control).

56 There is fundamental disagreement over the goals of incarceration and the role of prisons in achieving these goals. See supra note 15 and accompanying text. Compare the Supreme Court's decision in Rhodes v. Chapman, 452 U.S. 337 (1981), declaring: "To the extent that [prison] conditions are restrictive and even harsh, they are part of the penalty that criminal offenders pay for their offenses against society," id. at 347, with the position taken by the Prison Research Education Action Project: "Abolishing the punishment of prison is a fundamental step in abolishing the present punitive criminal (in)justice systems." Prison REsEARCH EDUCATION Action Project, supra note 15 , at 22. See also R. Martinson, T. Palmer \& S. Adams, Rehabilitation, Recidivism, AND RESEARCH 10 (1976) (finding that the various rehabilitative effects reported have in common their failure to curb recidivism); $H$. Packer, The Limits of the Criminal Sanction 36 (1968) ("[T]here are two . . ultimate purposes to be served by criminal punishment: the deserved infliction of suffering on evildoers and the prevention of crime."); Greenberg, The Correctional Effects of Corrections: A Survey of Evaluations, in 8 Correctrons and Punishment 111 , 140-41 (D. Greenberg ed. 1977) (advocating corrections programs committed "to the avoidance of illegal behavior" rather than "conventionally imagined therapeutic effects"); What Are Prisons For?, Tink, Sept. 13, 1982, at 38 (surveying American attitudes on the goals of correctional facilities and discussing current schools of thought in penology).

57 See Marshall, Correctional Trealment Processes: Rehabilitation Reconsidered, in Critical Issues in Corrections, supra note 19, at 31; Culbertson, Achieving Correctional Reform, in id. at 316. 
of this normative conflict, many corrections administrators will avoid articulating or pursuing a particular set of goals to avoid creating an inevitable controversy. 58

The public tends to be ignorant about and indifferent to the quality of prison conditions. ${ }^{59}$ Public outcry concerning prison conditions or the correctional system often only follows a publicized scandal, riot, escape, release of inmates due to overcrowding, or violent crime by a person who is under the jurisdiction of the corrections system. ${ }^{60}$ Public response to prison conditions tends to be episodic, reactive, and directed to restoring order (and invisibility) rather than restructuring prison practices to conform to a different norm. ${ }^{61}$ Legislators perceive the public as indignant about prisons' operating expenses and insistent upon cost-cutting. ${ }^{62}$

Legislators and executives are likely to respond to perceived public antipathy to prison reform by opposing all funding increases and reform initiatives except those intended to expand available prison space. ${ }^{63}$ The political system conveys to the prison bureaucracy a preoccupation with reducing costs and enhancing "incapaci-

58 See Cohn, supra note 44, at 125; of. L. CARroll, supra note 29, at 51 (explaining why the resources of the institution are not committed to any goal beyond self-maintenance, one guard said, "It's like having a ship without a rudder. . . . If you say we're supposed to rehabilitate people, we don't do that. If we're supposed to produce things, we don't do that either because we don't work them enough. And all these changes mean we don't punish them either. Nobody knows what we're supposed to do so we don't do anything").

59 See M.K. Harris \& D. SpILler, supra note 17, at 8-9; Giari, In Oklahoma, Building More Prisons Has Solved No Problems, 25 Crime \& Deline. 450, 454-55 (1979).

60 See The Organizational Consequences of Remedial Law, supra note 46, at 16; Toch, supra note 33 , at $69-70$.

61 See, e.g., T. WICKER, A Time to Die 278-98 (1975) (discussing how the public outcry over the violence during the Attica prison riots resulted in increased security and the imposition by prison authorities of more repressive means of maintaining order).

62 See, e.g., Austin, Using Early Release to Relieve Prison Crowding, 32 CRIME \& Deline. 404, 412 (1986) (noting that although the public favors " 'get tough' policies, they are not always willing to pay for them"); Mullen, Prison Crowding and the Evolution of Public Policy, 478 AnNals 31, 39 (1985) (explaining that the public's "reluctance to spend money on prisoners" is responsible for the lack of support for prison construction proposals); New Jails: Boom for Builders, Bust for Budgels, Bus. WK., Feb. 9, 1981, at 74-75 (relaying public sentiment as "[p]ut the prisoners in pup tents behind barbed wire and give the guards machine guns- that's good enough"). In part, this may reflect the view that prison conditions should be harsh and that prisoners have a weak claim on public resources.

63 See Giari, supra note 59, at 460-61. 
tation, control, and custody."64 This dynamic reinforces the prison system's commitment to order. ${ }^{65}$

\section{Paralyzed Proponents of Change: Inmates, Treatment Staff, and Progressive Administrators}

There are, nevertheless, some internal sources of support for the norms underlying reform. Inmates, treatment staff, and reformminded or professional managers may embrace the norm of promoting individual dignity and rehabilitation. However, reform-minded members of the prison community frequently lack the power and public support necessary to institutionalize their normative framework.

Inmates are the group most naturally interested in reform and supportive of the norm of promoting individual dignity and rehabilitation. Inmates continually suffer from the conditions violating the Constitution. Under the traditional, closed system of social control, their needs are subordinated entirely to the demands of maintaining order, discipline and, in some prisons, a productive labor force. ${ }^{66}$ Prison reform promotes the view that inmates deserve decent treatment and respect as individuals with basic human rights. ${ }^{67}$ The reform process elevates the prisoners' status both in the prison and in society generally. ${ }^{68}$

64 See Marshall, Correctional Treatment Processes: Rehabilitation Reconsidered, in Critical Issues in Corrections, supra note 19, at 31.

65 See, e.g., J. IRwIN, supra note 25, at 129-30 (noting that custody concerns dominate the decisionmaking process of even those who are committed to treatment); M. LIPSKY, supra note 25, at 44-45 (explaining how public service workers must sacrifice individual treatment in order to meet the requirements of mass processing).

66 See D. Rothman, The Discovery of the Asylum 102-04 (1971). The status of inmates in prison is a particular example of a more general phenomenon characterizing the status of clients in "street-level bureaucracies." See M. LipsKY, supra note 25 , at 57-58. Prisons exhibit a particularly pronounced version of the subordination of clients' needs and interests to the demands of processing, disciplining, and maintaining order due to their punitive purpose and their character as "total institutions"-institutions "symbolized by the barrier to social intercourse with the outside and to departure that is often built right into the physical plant ...." E. Goffman, supra note 25 , at 4-5.

67 See J. JACOBS, supra note 25, at 93; Jacobs, The Prisoners' Rights Movement and Its Impacts, in New Perspectives on Prisons and Imprisonment, supra note 29, at 35-45.

68 See, e.g., M.K. HARRIS \& D. SPILLER, supra note 17, at 203 (noting that reforms stemming from law suit were viewed as changing status of prison in eyes of Jefferson Parish officials and general citizenry). Politicized inmates link their status to broader patterns of racism and class domination in society and view prison reform as part of a larger goal of more fundamental political change. See J. IRwin, supra note 25, at 9498 ; Jacobs, supra note 67 , at 36 . 
Inmates may increase their autonomy by involving outsiders who do not share the perspective and concerns of the prison community. Outside scrutiny limits the discretion and authority of guards and administrators and increases the autonomy and freedom of the inmates. ${ }^{69}$ Many of the substantive changes sought and won in the courts involve limiting the discretion and arbitrary control of the prison officials (i.e. preserving the inmates' rights to due process) and enhancing the freedom of inmates (to exercise, participate in programs, read, communicate with the outside world, etc.). ${ }^{70}$

Despite inmates' natural potential to serve as catalysts for change, their institutional position, social and political status, and mechanisms for coping with the pains of imprisonment constrain their role in promoting prison reform. Inmates subject to daily deprivation and institutionalized powerlessness are likely to be most interested in enhancing their place within the prison's social structure. Power is an end in itself, a means of coping with the vulnerability of prison life and possibly even continuing power struggles that began on the street. ${ }^{71}$ This tendency is heightened by the existence of group affiliations that begin on the outside and continue within the prison. Inmates derive their sense of self, their support, their power, and their protection within the prison from the group. ${ }^{72}$ The ability to change conditions within the prison becomes a means of furthering the power and resources of the group, rather than a means of improving their living conditions. Thus, a large part of group activity within the prison is used to exert power over others within the prison, rather than to attempt to improve conditions generally.

The elite group of inmates who achieve power and prestige by bargaining with guards tend to have strong interests in maintaining order. Official support for their privileged position depends on their

69 See, e.g., Jacobs, supra note 67, at 36 ("Just by opening a forum in which prisoners' grievances could be heard, the federal courts destroyed the custodians' absolute power and the prisoners' isolation from the larger of society.").

70 See supra notes 16-18, 38 and accompanying text.

71 See B. Crouch \& J. Marquart, supra note 29, at 203; J. Irwin, supra note 25, at 8-16; see also Gigot, Assaults, Drug Traffic and Powerful Gangs Plague a Penitentiary, Wall St. J., Aug. 20, 1981, at 1, 19, col. 1 (reporting that prison authorities estimated that $80 \%$ of the inmates in Stateville belong to the five major Chicago gangs and that within the prison the gangs engage in a daily struggle for control).

72 See J. Irwin, supra note 25, at 60; see also Penn, Prison Gangs Formed By Racial Groups Pose Big Problem in West, Wall St. J., May 11, 1983, at 1, 24, col. 1 (reporting that inmates join gangs for self-preservation, protection, and access to favorable jobs and money). 
ability to maintain order. ${ }^{73}$ The perquisites of their status, such as access to privileged information, good food, privacy, and the ability to defy the institution's rules with impunity, ${ }^{74}$ provide significant incentives to adopt the normative commitment to order. Because change tends to open up the system of privilege and undermine their power, it is not uncommon for the old inmate elite to oppose prison reform. ${ }^{75}$

Treatment staff constitute another group within the prison that aspires to norms inconsistent with the status quo. Many treatment staff members bring to the job a commitment to the norm of promoting individual dignity and rehabilitation developed outside of the prison system. ${ }^{76}$ Their responsibilities are frequently diffuse, but clearly they define their role as providing individual inmates with support, advocacy, and counseling. ${ }^{77}$ Treatment staff therefore introduce into the prison system a limited form of internal accountability. Uncomfortable with their role in perpetuating inhumane prison conditions, counselors seemingly represent a constituency whose norms and interests coincide with the reform agenda. Inmate-oriented reform both conforms to counselors' goals and selfimage and enhances their power within the prison.

Despite this natural alliance with a change agenda, treatment staff are generally not an important internal source of change. They routinely encounter resistance to the efforts they make to provide services; counselors' challenges to the prevailing normative structure are almost always rebuffed. They are, for the most part, powerless in the face of the system-wide intransigence. Often counselors end up

73 See, e.g., B. Crouch \& J. MARQUART, supra note 29, at 41 (describing how the Director of the Department of Corrections in Texas maintained a building tender system because it was an important source of information and control). The ability of inmates to conduct illicit activities also depends upon the maintenance of order. See Colvin, supra note 42 , at 453.

74 See, e.g., B. Crouch \& J. Marquart, supra note 29, at 108-09 (describing privileges that flowed from elite status, such as pressed clothes, freedom of movement, permission to have weapons, and immunity from punishment).

75 See, e.g., Cloward, Social Control in the Prison, in Prison Within Society 78, 103-04 (L. Hazelrigg ed. 1968) (describing how the elite prisoners strongly defend their privileged position against encroachment by other inmates).

76 See, e.g., C. Prout \& R. Ross, Care and Punishment: The Dilemmas of Prison MEdicine 56-59, 81-82, 154 (1988) (describing how many of those on the staff of the prison health project saw themselves as health advocates for the inmates and were dedicated to the struggle for justice, liberty, and equal rights within the prison).

77 See J. JACOBS, supra note 25 , at 94. 
adapting their norms to conform to the institution's dominant ethic. $^{78}$

Reform-minded administrators appear to be uniquely situated to introduce norms consistent with change. Administrators interested in reform often come from outside the prison system they seek to change. ${ }^{79}$ Many have training in social work, counseling, or another therapeutic discipline, and have varying degrees of experience within a prison. ${ }^{80}$ These administrators bring to corrections the belief that the prison system's norms must be reoriented away from a primarily custodial or punitive orientation to focus on the inmates' needs for individual attention, rehabilitation, and services. ${ }^{81}$ Job satisfaction depends on success in implementing change. Thus, their normative framework and goals tend to conflict with the value system and normative framework of the existing custodial order.

Although reform administrators are a potential internal source of change, they also confront substantial obstacles to the pursuit of a reform agenda. A systemic preoccupation with order, shared by guards and conservative administrators and reinforced by the political system, undermines potential internal reformers' efforts to institutionalize their normative framework. Moreover, reform administrators frequently lack the information, expertise, and power necessary to implement change.

\section{B. Incentive System Reinforcing the Status Quo}

The system of incentives that has developed around each major group within the system tends to reinforce a normative commitment

78 See id. at 98-99.

79 See, e.g., L. Carroll, supra note 29, at 44 (explaining that the new warden, hired to move the prison in the direction of "therapeutic atmosphere," was an outsider to system); J. JACOBS, supra note 25, at 74-75 (noting that reform administration with strong academic orientation came from outside the system); McCleery, supra note 41, at 122 (describing how new warden and his top staff "were unfamiliar with and shocked by the detailed processes" of prison government).

80 See, e.g., Jacobs \& Crotty, supra note 29, at 140 (listing the warden's priorities as "(1) the procurement of professional treatment personnel and the establishment of treatment programs, (2) the education of his staff in the perspective of treatment ideology, and (3) a further relaxation of custodial measures"); $c f$. Cohn, supra note 44 , at $126-27$ (social work is seen as ideal educational background for correctional workers).

81 See, e.g., L. Carroll, supra note 29, at $48-50$ (noting the "new breed" of administrators that were college-educated in sociology and psychology); McCleery, supra note 41 , at $122-27$ (documenting new administration's commitment to reform and the rehabilitative ideal). 
to order at the expense of the individual. There are few, if any, positive incentives to challenge the status quo. Sanctions are rarely imposed for narrowly defining tasks and disclaiming responsibility for the prison's problems.

The risks and costs associated with seeking change outweigh the meager and uncertain benefits associated with undertaking reform. Prison officials are essentially left alone as long as they maintain order. Those in a position to facilitate or frustrate order tend to wield tremendous informal power within the prison and seek to retain the existing set of norms and incentives.

The status and condition of inmates diminishes their incentive to engage in reform activities. Imprisonment constantly reminds inmates of their vulnerability and dependence, reducing their will to act. Some prisoners respond by withdrawing; they define their existence very narrowly, focus on surviving their prison term, and simply try to stay out of the way of guards and fellow inmates and "do their own time." 82 Efforts to initiate change are shunned because they are likely to increase inmates' visibility and offend those in a position to retaliate against "trouble-makers." 83 Those most vulnerable may be the least willing or able to take an active role in challenging those conditions. ${ }^{84}$

Guards have strong incentives to preserve the status quo. Their performance is evaluated in relation to their ability to maintain order. ${ }^{85}$ Advancement may depend on demonstrating toughness and the ability to control inmates. ${ }^{86}$ By asserting authority and control, guards also seek to enhance their power and make their work

82 See J. IRwin, supra note 25 , at 197-205. This reaction is encouraged by the attitudes of prison authorities. See, e.g., Cloward, supra note 75, at 83 (noting that prison officials believe that "the model prisoner is the isolated prisoner").

83 See, e.g., Flittie, The Class Representative: A Personal Experience, 13 Nat'l Prison Project J. 19, 19 (1987) (describing life of class representative as "experienced various forms of retaliation by prison officials, threats, harassment, cell shakedowns, denied visits, denied parole three times, denied any outside the walls activities").

84 See Note, "Mastering" Intervention in Prisons, 88 YALE L.J. 1062, 1079 \& n.88 (1979).

85 See B. Crouch \& J. Marquart, supra note 29, at 56-57; M. LipsKy, supra note 25 , at $11-12$.

86 See, e.g., B. Crouch \& J. Marquart, supra note 29, at 53 (noting that to advance in the security hierarchy, officers must demonstrate a familiarity with the guard subculture, and thus "in the background of almost all ranking officers and wardens was a reputation for being able to manage, physically as well as psychologically, inmates who balked at compliance with rules or orders"'); Marquart, supra note 37 , at $358-60$. 
safer and more predictable. ${ }^{87}$ These values also promote guard autonomy. Guards are often subject to strict scrutiny from above and formal disciplinary measures. ${ }^{88}$ Like many workers, guards seek to increase their autonomy by defining a realm within the hierarchy that is under their exclusive control. ${ }^{89}$

By exploiting their discretion and autonomy, guards can create and benefit from a system of bargaining and exchange with inmates. Some guards, particularly veterans who worked under the old regime and have developed a power base within the prison community, illicitly supplement their income and benefits through the system of exchange worked out in part to maintain order..$^{90}$

Guards have few substantial incentives or opportunities to embrace a reform agenda. Opportunities for advancement are not tied to demonstrated commitment to efficient and sensitive service delivery. ${ }^{91}$ Salary and benefits are strictly governed by seniority and civil service provisions and thus do not relate to the quality of service delivery. ${ }^{92}$ Guards have few incentives to support reform efforts initiated by those who embrace a contrary perspective and for whom they have little empathy.

Guard unions and senior guards may exert substantial pressure upon the rank-and-file workers not to engage in reform activity. Those who support reform efforts perceived by the union or its senior membership as inconsistent with the union's interests are often ostracized or otherwise informally punished. ${ }^{93}$ Demoralized

87 See, e.g., B. Crouch \& J. MARQUART, supra note 29, at 56-60 (explaining how guards maintained control through a show of force).

88 See, e.g., J. JACOBS, supra note 25, at 39 (describing tight control exercised over guards); L. LOMBARDo, supra note 25, at 134 (describing infantilization and dehumanization of guards by administration); Jacobs \& Crotty, supra note 29, at 139 (noting that a "line officer is often scrutinized as closely as the inmate under his surveillance").

89 See L. Lombardo, supra note 25, at 45-46; cf. M. Crozier, supra note 24, at 5455 (explaining that people build bureaucracies to evade dependence and obtain protection from arbitrary decisions).

90 See, e.g., C. Silberman, supra note 33, at 402 (explaining that prison officials regulate, rather than suppress, illegal activity); B. Chilton, Guthrie v. Evans: Civil Rights, Prison Reform, and Institutional Reform Litigation 91 (1989) (unpublished dissertation) (describing how guards allowed inmates to keep weapons and sell contraband).

91 See L. Lombardo, supra note 25, at 152.

92 See infra note 127 and accompanying text; see also M. LIPSKY, supra note 25 , at 48-52 (describing difficulty of developing effective performance measures and institutionalizing them in street-level bureaucracies).

93 See Sturm, The Rhode Island Prison Decree, in G. Hazard \& D. Louisell, Cases on Pleading and Procedure 110, 114 (4th ed. 1979). 
and dissatisfied employees will typically resign or decrease the extent of their commitment to their job rather than support change. ${ }^{94}$ Indeed, guards often use their seniority to obtain positions that enable them to avoid interaction with inmates and other staff, such as tower duty. ${ }^{95}$ Inmates create further pressure for guards to limit their involvement. In prisons where group conflict is pervasive, prison officials have themselves sometimes responded by withdrawing and abdicating responsibility for prison conditions to the prisoners themselves. ${ }^{96}$

Treatment staff similarly confront substantial disincentives to pursuing reform. They tend to receive meager support for their work from the administration. ${ }^{97}$ They are frequently hired in insuffcient numbers relative to their caseload. ${ }^{98}$ The prison administration rarely provides them with the assistance necessary to improve their human services capacity. Instead, in addition to huge caseloads, they are given responsibility for significant bureaucratic functions, such as processing requests for information, evaluating inmates, sitting on disciplinary committees, and expediting information. ${ }^{99}$ Counselors tend to find their human services duties subordinated to people processing. ${ }^{100}$

94 See M. LIPSKY, supra note 25 , at 142-43 (describing how in the face of their perceived loss of power, autonomy, and status within the prison, some guards adapt by withdrawing from the workplace, either by leaving or by "withdraw[ing] psychologically without actually quitting, rejecting personal responsibility for agency performance"); see also Gigot, supria note 71, at 1, col. 1 ("Many honest guards are afraid and frustrated, which helps to explain why $25 \%$ of the guards call in sick each day.").

95 See Toch, supra note 33, at 62.

96 See J. Irwin, supra note 25, at 23-24; C. Silberman, supra note 33, at 399; see also Lieber, The American Prison, N.Y. Times, Mar. 8, 1981, § 6 (Magazine), at 26, 35, 57 ("[O]fficers often appear to hang back in the sally ports and administrative desk areas ... [I]n many institutions guards will not even go into the buildings at night, a procedure that permits unbridled conduct among inmates."). Inmates' resulting power and autonomy predisposes leaders of inmate groups to resist any steps that would cut back on that autonomy and power.

97 See, e.g., C. Prout \& R. Ross, Care and Punishment: The Dilemmas of Prison Medicine 81-82 (1988) (documenting the lack of support received by prison health project from administration and legislature); J. JACOBS, supra note 25, at 96-98 (documenting how counselors backed down in a dispute over their role in the prison when they failed to receive any administrative support).

98 See, e.g., Lieber, supra note 96, at 35, 56 (reporting that in Indiana, where ten counselors are on the staff, if they work eight hours a day interviewing inmates, they cannot give each prisoner an hour per month of services).

99 See, e.g., J. JACOBS, supra note 25, at 97-100 (documenting counselors' assignment of "go for" duties and participation on numerous prison committees).

100 See, e.g., L. YACKLE, supra note 51, at 86, 138-39 (noting that expert at trial reported that classification teams ignored their own procedures in a rush to move 
Guards frequently resist the treatment staff's efforts to perform their duties. As relative newcomers to the prison system, the college-educated counselors challenge the existing control model, ${ }^{101}$ and threaten guards' status within the prison. ${ }^{102}$ Counselors undercut guards' role by taking over the treatment and advocacy functions previously performed by guards. ${ }^{103}$ Treatment staff intensify guard hostility by frequently siding with inmates in disputes with guards.

Counselors also encounter resistance from inmates. Counselors, teachers, and other civilian staff often take over some of the jobs previously occupied by inmates. ${ }^{104}$ Furthermore, inmatés are not always willing participants in the rehabilitative enterprise. The structure of service delivery in the prison predisposes them to view "rehabilitation" as another form of social control. Instead, they tend to use counselors as advocates to intervene on their behalf in institutional problems and as a means of getting information and services. ${ }^{105}$

Limited expertise and support inhibit the ability of treatment staff to pursue goals contrary to the prevailing ethic. Counselors lack the professional skills and status to make a strong case for independence and discretion, even in the performance of their counseling

prisoners through the system). See generally M. LIPSKY, supra note 25, at 140-42 (analyzing the tendency of street-level bureaucrats to focus on people-processing rather than counseling, treatment, or advocacy).

101 In the wake of renewed interest in the 1950s and 1960s in the prison as a vehicle for rehabilitating offenders, civilian staff and professionals were hired to perform service functions for the inmates. Although previously there were professionals who provided medical services and limited psychiatric services, they were usually part time, had huge caseloads, and were uninvolved with the day-to-day functioning of the institution. In the 1950s and $1960 \mathrm{~s}$, prisons began to hire full time civilian staff to perform many of the service functions previously performed by guards. See Jacobs \& Crotty, supra note 29, at 140.

102 See, e.g., J. JACOBS, supra note 25, at 96 (noting that the introduction of , counselors traumatized the guard force because they posed a threat to the ultimate control of the prison).

103 See, e.g., id. at 96 (reporting that counselors were hired to carry out "clean work" previously performed by guards while guards continued to be responsible for "dirty work").

104 See, e.g., M.K. Harris \& D. SpIller, supra note 17, at 111 (discussing the "converting [of the Arkansas] prison system from a system run by inmates to a system run by free personnel"); J. JACOBS, supra note 25, at 93 (noting that the introduction of civilian counselors "served to eliminate inmates from some of the most self-respecting work in the prison"); Colvin, supra note 42 , at 454 (noting that the administration removed all inmates from administrative positions in programs).

105 See, e.g., J. JACOBS, supra note 25, at 95 ("'[I]nmates were more interested in enlisting the counselors as advocates than as therapists."). 
duties. ${ }^{106}$ Counselors often respond to this situation by quitting or withdrawing from the job psychologically. ${ }^{107}$ Others embrace the control function of the institution and become more actively involved in administrative processing activities. ${ }^{108}$ Neither of these approaches serves as an impetus to institutional change.

Prison administrators face substantial pressures, both from within the prison system and from the external political environment, to avoid rocking the boat. They are immediately accountable to the political official who appointed them, whose major concern, in many cases, is "keeping the lid on" the prison system. ${ }^{109}$ Given the political powerlessness of inmates and the lack of widespread support for prison reform, there is little political advantage to be gained by pursuing corrections reform. Not surprisingly, corrections tends to be low on the state's list of policy priorities. The governor is often concerned with keeping inmates in, costs down, and visible disturbances out of the news. Thus, administrators are expected to avoid major scandals or disruption. Failure to do so may lead to a change in administration and will certainly lead to a loss of the current administration's credibility. Because change is perceived as posing a substantial risk of disruption, the governor's office frequently enhances the pressure toward custody, order, and the status quo.

The budgetary process frequently reinforces this drive to preserve the status quo. Concerned with keeping costs (and taxes) down, the governor and his or her budgetary staff frequently use current programs, staffing, and resources as the framework for the next year's allocations. ${ }^{10}$ Unless there is a dramatic increase in prison population; there is little support for a substantial increase in fund-

106 See, e.g., id. at 94 (noting that counselors were not social workers or psychologists, and only a few had any experience in any kind of counseling).

107 See, e.g., id. at 98 (describing counselors' passive revolt against the organization, during which they "retreated into psychological alienation and physical isolation"); M. Lipsky, supra note 25, at 143 (noting that the discrepancy between what workers are supposed to do and what they can actually accomplish led many either to quit or to withdraw psychologically).

108 See, e.g., M. LIPSKY, supra note 25, at 144.

109 See, e.g., Sturm, supra note 93, at 116; see also B. McEleney, Correctional Reform in New York: The Rockefeller Years and Beyond 30 (1985) (noting that the "Governor's priority . . . was . . . a pragmatic maintenance of the status quo in most issue areas. ... Because Corrections had traditionally been accorded a low priority and there were ... no public riots nor demonstrations within the prisons that demanded Gubernatorial reaction, the Division of the Budget was granted virtual autonomy in the trimming or amendment of the original Correction Department budget").

110 See B. McEleney, supra note 109, at 26-31; T. Storey, Courts and Corrections: The New York City Jail Litigation 8 (1988) (unpublished paper) (on file 
ing, particularly for innovative or service-oriented programs. ${ }^{111}$ Because many prison systems are critically overcrowded, money that might otherwise have been budgeted for improvements in the quality of service delivery is likely to be diverted to provision of additional bed-space. ${ }^{112}$

Administrative reform also tends to trigger strong and immediate resistance from the guard force-both line staff and supervisors. ${ }^{13}$ The normative structure, values, and incentives of the guards predispose most to perceive the reform administrator as threatening to the guards' role, autonomy, and power. ${ }^{14}$ Through withdrawal, disruption, and resistance, guards can neutralize policy reforms and force new administrators to deal with immediate crises of control, diverting attention and energy from reform programs. ${ }^{115}$ The resulting publicity and disorder threaten the fragile external support structure upon which the administrator depends. The governor and sympathetic legislators, concerned about the potential for disruption, have strong incentives to back down in the face of opposition. ${ }^{116}$

with the University of Pennsylvania Law Review) (stating that the budget process "tended to magnify the low level of political support jails received").

111 See, e.g., Judges' Authority in Prison Reform Attacked, N.Y. Times, May 18, 1982, at A1, col. 2, A21, col. 2 [hereinafter Judges'Authority] (reporting that New York State voters "rejected a $\$ 500$ million bond issue intended to provide more state and county cell space"); supra note 62 (noting public reluctance to spend money on prisons).

112 See, e.g., Giari, supra note 59, at 454 (noting that when the Oklahoma legislature authorized funds for new construction, it slashed operating expenses); Thomas, Stribling, Chaka, Clemons, Secret \& Neal, Prison Conditions and Penal Trends, Crime \& Social Justice 49, 49 (Summer 1981) (reporting that in Illinois, less than $.006 \%$ of the total corrections budget was allocated to improving existing conditions). Overcrowding not only threatens the viability of programs designed to improve prison conditions, but also degrades the quality of existing services, since increases in population frequently are not accompanied by increases in staff, services, or equipment. See Toch, supra note 33 , at $62-65$. Thus, overcrowding dramatically increases the pressure toward mass processing at the expense of meeting the basic human needs of inmates. See Ellis, supra note 33, at 296.

113 See, e.g., J. JacoBs, supra note 25, at 176 (describing the resentment of the Stateville prison guards when reform was instituted by the new "pro-inmate" warden).

114 See, e.g., id. at 82-83 (describing the increasing embitterment of the Stateville guards as their traditional roles were undermined by reform measures).

115 See L. Lombardo, supra note 25, at 164-66. Guards derive some power simply from their longevity in the organization. Many are likely to have seen administrations come and go, along with their various reform proposals. See, e.g., J. KNOTT \& G. Miller, supra note 20, at 158 (describing the relative control of the president over lower-level permanent bureaucrats, who know that they "will still be there when the present administration has come and gone").

$116 \mathrm{Cf}$. Alexander, supra note 51, at $970 \& \mathrm{n} .38$ (explaining that, in order to 
The corrections profession also fails to provide sufficient external incentives for administrators to undertake reform. Although there are professional organizations, such as the National Institute of Corrections, that provide technical assistance and expertise to state systems seeking such suppart, ${ }^{117}$ the corrections profession has not developed the power, visibility, or credibility to counteract the local pressures facing corrections administrators. The profession lacks the capacity to hold its members accountable for their performance. ${ }^{118}$ Until recently, most prisons functioned as isolated, inwarddirected systems with little outside contact. ${ }^{119}$ Some administrators continue to resist the input of national professional organizations and outside expertise, and perceive the development of professional standards as an imposition on their autonomy. ${ }^{120}$ Many state and local prison administrators continue to function with little substantive interaction with others in the discipline.

Thus, members of the prison community have few effective incentives supporting their efforts to introduce significant change.

avoid adverse publicity, the new administrator will "take a firm stand only against rampant brutality while accommodating union demands that guards not be held accountable for isolated incidents of force against inmates").

117 The National Institute of Corrections is a federal agency that plays a significant role in promoting progressive reform in prisons. It has sponsored research conferences and training: programs in such areas as the development and implementation of grievance procedures and the training of special masters to carry out their role of monitoring court decrees in prison cases. Seef J. JACoBs, supra note 29, at 47. The American Correctional Association serves as a mechanism for exchanging information and ideas. "More important is the ACA's substantial accreditation project ... which attempts to hold state and local prisons and jails to comprehensive and progressive confinement conditions and practices." Id.; see AM. Correctional Ass'n, ACCreditation: Blue Print for Corrections (1978).

118 See Cohn, supra note 44, at 128. For this reason, some argue that the accreditation process set up by the American Correctional Association has not been effective in achieving broad scale compliance with minimum standards of decency. See Conrad, Charting a Course for Imprisonment Policy, 478 Annals 123, 124 (1985).

119 See, e.g., M.K. Harris \& D. SpIller, supra note 17, at 84 (recounting that the Arkansas prison system was closed to public and court scrutiny prior to 1965); J. JACOBS, supra note 25 , at $19,35-37$ (noting that prison officials were reluctant to involve intellectuals in the daily operations of the prison and restricted public access to the prison in order to suppress the flow of information about the prison to "outsiders").

120 Cf. Conrad, supra note 118 , at 124 (noting that "the Maryland legislature has prohibited its prison administrators from spending state funds to engage in the accreditation process"). There are strong indications that high-level corrections administration is in the midst of a trend toward professionalization, see infra notes 248 \& 338 , influenced at least in part by pressure generated by judicial intervention. 


\section{Inadequate Information Exchange and Expertise}

Prison systems generally lack mechanisms for gathering information about daily activities and communicating it to those in policymaking positions. ${ }^{121}$ Administrators tend to have little contact with or knowledge of day-to-day activities within the prison and are dependent on those inside for information. Administrators tend to be isolated from the informal network of relationships that effectively governs daily life in the prison system. Guards and inmates, who possess information about how the system is functioning, frequently have neither the incentive nor the opportunity to communicate this information to the administration.

Guards have firsthand knowledge of the prison's potential problem areas, inmates' responses to the system, and how proposed changes are likely to affect their work. However, guards have no formal access to high-level administrators and, like many street-level bureaucrats, are likely to suppress negative information that might adversely affect their position in the organization. ${ }^{122}$ Administrators frequently contribute to this tendency by stereotyping guards as incompetent and resistant to change. ${ }^{123}$ Rather than rely on insiders for information and advice regarding policy, administrators often remove themselves from direct contact with the prison and surround themselves with a cadre of outside staff who are sympathetic to the

121 See, e.g., M.K. Harris \& D. SpILler, supra note 17, at 299 (describing the record-keeping system in Orleans Parish Prison as nonexistent or indecipherable); M. Lipsky, supra note 25, at 29 (describing the general absence of mechanisms for effective information exchange in street-level bureaucracies); Plan: Corrections Panel, Spear v. Ariyoshi, November 5, 1985, at 13 (indicating that creation of a management information system is crucial to safe and orderly operations).

122 See, e.g., The Center for Community Justice, Prison Grievance Mechanisms Manual 19-20 (1977) [hereinafter Prison Grievance Manual] (describing the control over information flow enjoyed by line officers); see also M.K. HARRIS \& D. SpILLER, supra note 17, at 36-39 (documenting that silence about guard and prisoner behavior in general and about the informal use of force by officers in particular is an important norm); L. LOMBARDO, supra note 25, at 126 (documenting inadequate communication between departmental and institutional administration and corrections officers). This lack of communication between guards and administrators is a particularly acute example of a general pattern in bureaucracies: subordinates are afraid or unwilling to pass bad news up the organizational ladder. See C. Stone, Where the LaW Ends 61 (1975); H. Wilensky, Organizational INTElligence: Knowledge and Policy in Government and Industry $42-48$ (1967). This tendency is particularly pronounced in organizations in which there is little perceived benefit in risk taking. See C. PERrow, N supra note 25, at 29, 33-34. 140.

123 See L. Lombardo, supra note 25, at 122; Jacobs \& Crotty, supra note 29, at 
reform agenda. ${ }^{124}$ Guards typically have no role in developing or implementing changes that profoundly affect their work, are basically excluded from any access to decisionmaking or policy, and lack an effective means of communicating information about the problems of the current system. ${ }^{125}$

Unionization has enhanced the power of guards and their capacity to express their concerns about prison conditions and practices. Management must deal with guards' concerns at least in the context of contract negotiations and grievances. In some instances, guard unions have introduced concerns about prison overpopulation, guards' powerlessness, and the failure to control inmate violence. ${ }^{126}$ The context of the interaction between guards and management is quite limited, however, and ordinarily does not address the kinds of policies and behavior that contribute to unconstitutional prison conditions. Management has been quite resistant to the involvement of guard unions in administrative decisionmaking and has for the most part treated union negotiations as a separate management problem to be handled. Moreover, unions have frequently focused their attention on increasing their control over job and shift assignments, preserving the interests of senior guards, and increasing guards' pay and benefits. ${ }^{127}$

124 See, e.g., J. JACOBS, supra note 25, at 83-84 ("For the captains who once made and interpreted policy, access to the warden became increasingly restricted. The formulation of policy became increasingly separate from its implementation."); McCleery, supra note 41, at 133 (describing how, in his role as superintendent, one former treatment worker "gradually became less receptive to the transmission of problems from below, limited the access of subordinates to the warden, and permitted the atrophy of various channels of communication which had marked the administration in its most vigorous phase").

125 See L. Lombardo, supra note 25, at 123-25 (describing guards' lack of opportunities for effective input); Hepburn, supra note 40 , at 51 ("Prison guards frequently and publicly voice their feeling that they have too little influence in decisions about the operations and goals of the prison.").

126 See J. JACOBS, supra note 29, at I43-46; J. WynNE, supra note 43, at 214-15; see also ACI Guards Protest Overcrowding; Cite "Mismanagement", Providence J., Sept. 16, 1988, at 4, col. 1 (reporting that the union would conduct a peaceful picket but threatened to strike to protest overcrowding, mandatory overtime, staff shortages and general mismanagement).

127 See, e.g., J. WYNNE, supra note 43, at 156-87 (characterizing the chief product of collective bargaining between prison management and guards' unions as contracts primarily dealing with economics, employee organizations, and operations, and noting that " $[\mathrm{m}]$ ost employee demands that directly affect policy . . . are not settled through collective bargaining"). Union control over job assignment has, in some systems, contributed to the problem of maintaining order because unions have assigned jobs based on seniority. As a result, those with seniority have selected jobs with little inmate contact, relegating the jobs requiring the greatest skill and 
Inmates are in a position to experience directly the prison system's failures. They know how bad the food is, who is abusing inmates, how the medical care system is failing, which guards are dealing in contraband, and which inmates are terrorizing others. Yet inmates rarely have the opportunity to communicate information about systemic inadequacies to those with the formal power to implement change. ${ }^{128}$ Although some systems have instituted inmate grievance mechanisms that provide some outlet for inmate complaints, the scope of these systems and the degree to which they are integrated into policymaking is usually restricted. ${ }^{129}$ In addition, inmates have few incentives to communicate this information to prison officials. In fact, the inmate code strongly sanctions giving information to or forming relationships with prison officials. ${ }^{130}$

Consequently, administrators frequently lack the information essential to making an accurate assessment of the current status of the institution when addressing immediate problems or developing long-range policies. ${ }^{131}$ This dearth of information is exacerbated by the absence of a professional network of resources and expertise to facilitate the development of creative, pragmatic approaches to corrections. $^{132}$

\section{Insufficient Power to Institutionalize Reform}

Prison administrators sit at the top of the formal prison hierarchy. ${ }^{133}$ They are the individuals responsible for establishing policy,

experience to the most junior, least experienced guards. See supra note 95 and accompanying text.

128 See Prison Grievance Manual, supra note 122, at 19-20.

129 See id. at 15-21.

130 See, e.g., B. Crouch \& J. Marquart, supra note 29, at 74 (asserting that the universal element of the inmate code is that inmates will not give information to authorities about other inmates on pain of ostracism or even death); G. SYKES, supra note 25, at 87 (describing the label "rat" or "squealer" as "the most serious accusation that one inmate can level against another"). As an inmate in Alabama put it, "if you wanted to live and be healthy you kept your mouth shut no matter what."

L. YACKLE, supra note 51, at 88 n.6.

131 See Prison Grievance Manual, supra note 122, at 20.

132 See Cohn, supra note 44, at 127-28 (criticizing the absence of a professional body of knowledge and strong professional referent group); $c f$. Gilmore \& McCann, Designing Effective Transitions for New Correctional Leaders, in Criminal Corrections: IdEALS AND Realities 125, 131 (J. Doig ed. 1983) (asserting that prison executives should have a "national professional network" in order to discuss common concerns but that in reality few executives are "connected with well-developed networks of this kind").

133 Most prison systems today have a centralized administration, with a commissioner or director bearing responsibility for setting policy, submitting the 
implementing change, and managing the organization. They also must implement judicial decrees. Based on the organizational chart, prison administrators appear to have substantial power to determine agency policy and direction. If competent administrators could use their formal powers to bring about change, then the solution to prison problems would be relatively straight-forward: develop and hire competent administrators.

Despite their formal power, administrators often lack the resources, information, and support needed to implement reform. They are essentially dependent on their capacity to persuade relevant actors to cooperate. Administrators must rely on guards, staff, and inmates for implementation of new rules and programs. They must depend on executive officials, legislators, and judges for necessary resources and population control. The structure and politics of the prison community create both the opportunity and the incentive to resist and frustrate administrative attempts at reform.

Guards' pivotal role in processing inmates and maintaining order affords them the opportunity to resist change effectively in several ways. Resistance and disruption provide guards their most effective means of exerting power. Guards can refuse to maintain order or even promote disorder. ${ }^{134}$ They can engage in a work slowdown or strike. Although some jurisdictions impose legal impediments to such collective action, ${ }^{135}$ the threat of a strike and the potential disruptive effects of such an action give guards considerable power to influence administrators. ${ }^{136}$

Guards can use disorder within the prison, even in the absence of a strike, to undercut administrative initiatives. By refusing to act, failing to exercise the authority necessary to maintain control, and in some instances actively contributing to disruption, guards can place

budget, dealing with the legislature and the governor, supervising the department. Depending on the size and structure of the department, there may also be assistant directors or commissioners responsible for overseeing particular substantive areas, such as treatment, security, and personnel. In addition, a warden or superintendent has responsibility for overseeing the day-to-day functioning of a particular prison. See Gilmore \& McCann, supra note 132 , at 125.

134 See L. LomBardo, supra note 25, at 164-65; J. WYNNE, supra note 43, at 20407.

135 For example, see New 'York State's Taylor Law, Public Employees Fair Employment Act, N.Y. Civ. Serv. Law § 210 (McKinney 1983 Supp. 1990), which provides sanctions against individual strikers (two days salary lost for each day on strike), see id. at $\$ 210$ (2) (g), and the union (loss of dues check off), see id. at $\$ 210$ (3), if it has authorized or condoned the walkout. In addition, courts, at the request of the state, may issue injunctions against such walkouts, see id. at $\$ 211$.

136 See Alexander, supra note 51, at 970. 
considerable pressure on administrative reformers to return to the traditional control model of administration. ${ }^{137}$

Guards also possess considerable power in the form of discretion and resistance. Because of the nature of their work and the hierarchical structure of the organization, it is very difficult for higher ups to hold them accountable for implementing changes instituted from above. Guards can simply refuse to implement change or can communicate new policies in such a way as to thwart their effectiveness. ${ }^{138}$ Guards can and do reinterpret administrative policies into goals and practices that fit within their routines and serve their own ends of maintaining order, authority, and autonomy. ${ }^{139}$

Administrators have only limited power to overcome internal resistance to reform. ${ }^{140}$ They frequently lack effective control over employee policies such as hiring, promotion, transfer, salary, and discipline. ${ }^{141}$ Those who attempt to take direct steps to discipline, transfer, or assign guards face strong resistance from the guards or the union. ${ }^{142}$ Similarly, inmates who perceive proposed reforms as threatening their status or interests, or who perceive that the reforms are insufficient, can thwart implementation by resisting programmatic changes. ${ }^{143}$ Thus, administrators are limited in their capacity to influence the conduct of powerful groups within the prison whose interests may conflict with their reform agenda.

In addition to the obstacles posed by the internal power structure, the administrator's power to bring about change is reduced by the absence of a viable political constituency that supports expenditures necessary to improve prison conditions. ${ }^{144}$ The administrator is dependent on legislative and executive support for new programs and increased expenditures to improve existing facility, staffing, and

137 See, e.g., McCleery, supra note 41, at 138 (arguing that "the custodial force [of Ohau Prison] did not really try to quell the riot. It was as though they took the position that the superintendent, having started the trouble, could take care of it himself").

138 See L. Lombardo, supra note 25 , at $124,167$.

139 See M. LIPSKY, supra note 25, at 13-14; C. Silberman supra note 33, at 407-08.

140 See supra text accompanying notes 134-36.

141 See J. Knott \& G. Mrller, supra note 20, at 157-58; $c f$. G. Chase \& E. Reveal, How to Manage in the Public Sector 69 (1983) (noting the inability of public managers to control hiring, firing, and promotion).

142 See infra note 115-16 and accompanying text.

143 See infra notes 159-62 and accompanying text.

144 See, e.g., F. Rourke, Bureaucracy, Politics, and Public Policy 64-69 (1969) (discussing the variable power of a public agency, and arguing that the extent of an agency's power depends on the prestige, geographic dispersion, and organization of its clientele). 
services. Frequently change can only occur with the infusion of new resources into the system. ${ }^{145}$ Moreover, many of the most pressing problems within the prison are related to inadequate facilities, staff, and other resources. ${ }^{146}$

Legislators and high level executive officials are frequently resistent to requests for increased expenditures to improve prison conditions. ${ }^{147}$ Many legislators are concerned with avoiding the appearance of coddling criminals, and because of inmates' lack of political power, stand to lose little in the way of electoral support for taking a hard line on prisons. ${ }^{148}$ To the extent that corrections has been the repository for political patronage appointments, legislators are also unlikely to support a regime that will undercut their informal relationships with the prison.

Even in the face of riots, violence, or public exposure of brutal conditions, legislatures frequently provide minimal support for change. The familiar study commission or task force conducts a public hearing or investigation, culminating in a report with recommendations that are infrequently enacted into law. ${ }^{149}$ Even when the legislature does respond to abuse with legislation, there is little accountability for its enforcement and the administration may comfortably ignore it without legislative sanction.

The administrator depends on outside agencies to control the size of the population within the prison. Prison administrators have

145 See M.K. HaRRIS \& D. SPILlER, supra note 17, at 7; cf. H. KaUfMaN, supra note 22, at 23-31 (describing how resource limitations can prevent organizational change).

146 See, e.g., Judges' Authority, supra note 111, at A21, col. 2 (suggesting that the courts and state officials in states where severe financial constraints result in a lack of prison resources generally have the greatest difficulty instituting reforms).

147 See, e.g., M.K. Harris \& D. SPILler, supra note 17, at 15-16 (noting that the legislature and city administration resisted reform initiatives and refused to appropriate the additional funds necessary to accomplish change); supra note 62 (noting public reluctance to spend money on prisons).

148 See M.K. Harris \& D. SpILler, supra note 17, at 84 (noting that public opinion against prison reform was perceived clearly by the Arkansas legislature, "which was described as adamantly opposed to appropriating money for prison operations during the period preceding Holt v. Sarver"); cf. What Are Prisons For?, TIME, Sept. 13, 1982, at 41 (describing how legislators chastised corrections commissioner for being " "soft on crime" " and noting that "the people at home want us to get tough' "(quoting Mississippi Corrections Commissioner Thigpen)).

149 See, e.g., B. Crouch \& J. MARQUART, supra note 29, at 118-19 (finding that an investigation by joint House and Senate legislative committee produced numerous indictments of Texas prison system and recommendations for change, yet produced no results); Mullen, supra note 62, at 43 ("Most task forces have essentially performed as study groups whose ultimate accomplishment consists of a set of recommendations for change. ... [I]n too many cases the effect of commission recommendations has been negligible."). 
virtually no direct control over who is admitted to prison and limited control over which inmates will be released. Legislatively-determined sentencing policy and cutbacks in good time and other early release programs have recently contributed to prison overcrowding by increasing the proportion of individuals sentenced to prison. ${ }^{150}$ Judges implement sentencing policy, thereby determining on a dayto-day basis how many new inmates will be added to the prison population and how long they will remain in prison. ${ }^{151}$ Parole boards determine when inmates will be released prior to the expiration of their sentence. ${ }^{152}$ None of these organizations takes formal responsibility for prison conditions; none is accountable to the prison administration; and none has strong incentives or channels for taking correctional concerns into account. ${ }^{153}$

Thus, the administrator's capacity to control the size of the prison population is limited. Overpopulation is a fact of life in American prisons today, and it is a major obstacle to meaningful programmatic reform. ${ }^{154}$ Overcrowding strains resources, undercuts the capacity to meet inmates' basic needs, exacerbates tensions, and heightens the tendency to process inmates efficiently at the expense of individual needs. ${ }^{155}$ Yet in the absence of judicial pressure, administrators are often unable to develop the coordinated, systemic approach to the overpopulation problem that is necessary

150 See Austin \& Krisberg, Incarceration in the United States: The Extent and Future of the Problem, 478 Annals 15, 27 (1985); see also B. Crouch \& J. MarquaRT, supra note 29, at 120-21 (attributing growth of Texas prison population to strong community and legislative attitudes against convicted offenders and tough sentencing sentiment); Edelson, Court Orders South Carolina to Comply with Decree, 9 NAT'L Prison Project J. 4 (Fall 1986) (noting that the stricter sentencing statutes passed by the South Carolina Legislature contributed to increased prison population).

151 See, e.g., M.K. Harris \& D. SPILler, supra note 17, at 159 (noting that "on the few occasions when the population of the prison had exceeded the limit, the judge had been notified and the population reduced in less than the allowable time").

152 See 4 Wharton's Criminal Procedure $\$ 622$ (C. Torcia ed. 12th ed. 1976); Finn, Prison Crowding: The Response of Probation and Parole, 30 Crime \& Deling. 141, 142-49 (1984) (documenting impact of probation and parole practices and policies on overcrowding).

153 See J. KNOTT \& G. MiLlER, supra note 20, at 146-50 (noting that multiplicity of decision centers leads to "functional fiefdoms"); Finn, supra note 152, at 149 (noting that some governors, legislatures, judges and district attorneys have publicly objected to use of parole to reduce population and that media publicity surrounding crimes committed by parolees has generated hostility to the use of parole).

154 See, e.g., supra notes 33; see also M.K. HARris \& D. SPILler, supra note 17, at 7 (commenting that overcrowding in the Arkansas system resulted in inmates sleeping on cell floors and in corridors).

155 See Toch, supra note 33, at 59-61; supra notes 33 \& 154. 
to remedy it. ${ }^{156}$ Thus, administrators who undertake the goal of prison reform face significant constraints on their power to influence the behavior of actors within the prison system and its political environment.

Other change agents within the prison system lack the power to mobilize resources and support necessary for reform. Although inmates possess significant sources of power to initiate reform, their transformative role is limited by their institutional position, social and political status, and the mechanisms they develop for dealing with the difficulty of imprisonment. Treatment staff are extremely limited in their power to implement change.

One important source of inmates' power is their ability to expose the prison system's inadequacies. As inmates gain access to lawyers, legislators, and the media, they develop the capacity to use their information about abuses within the system in order to involve outsiders in the prison and create pressure on prison officials to explain or change prison practices and conditions. ${ }^{157}$ Prison officials' autonomy and control depend on the insulation of the prison from meaningful outside scrutiny. ${ }^{158}$ By exposing inadequacies in the prison system, inmates retain a potent means of circumscribing official autonomy and influencing outsiders' perspective on the prison.

Inmates also possess substantial power based on their capacity for disruption and violence. ${ }^{159}$ Guards can perform their jobs successfully only if inmates cooperate with them. ${ }^{160}$ Guards' desire to

156 See, e.g., Conrad, supra note 118, at 127 (calling for a systemic, integrated approach to penal policy to address overcrowding); Mullen, supra note 62 , at 34 (describing the need for a coherent corrections policy).

157 See, e.g., Cobb, Home Truths About Prison Overcrowding, 478 Annals 73, 83 (1985) (inmate author describing how he kept in constant contact with media to promote change and protect himself from retaliation).

158 See, e.g., S. Martin \& S. EkLand-Olson, Texas Prisons: The Walls Came Tumbling Down 24 (1988) (noting the censoring of prisoner communications as a means of preserving authority in Texas prisons); C. Silberman, supra note 33, at 396 (discussing the destruction of prisoner initiative by means of a near-monopoly on information). To preserve this autonomy, prison officials, like other officials in closed institutions, develop patterns of institutional display designed to give visitors an "appropriate image" of the institution, insulating the less socially acceptable conditions and forms of social control from outside intervention. See E. Gofrman, supra note 25, at 102, 106.

159 See, e.g., B. Chilton, supra note 90 , at 79 (describing inmates' strikes as a means of obtaining an audience with prison officials).

160 In some systems, guards' dependency on inmates to maintain control is formalized. For example, in Texas, prior to the court's intervention, inmates had supervisory authority over other inmates, and used violence and the threat of 
obtain cooperation and avoid disruption gives inmates substantial power. Similarly, administrators are predisposed to focus primarily on maintaining order and avoiding disruption. ${ }^{161}$ Violence and the threat of violence force administrators and the public to pay attention to inmate concerns, at least to the extent necessary to restore and maintain order. ${ }^{162}$ It also may have the effect of provoking public debate about prison conditions and attracting the attention of advocacy groups to the plight of inmates. ${ }^{163}$ Thus, inmates have the potential to serve as a catalyst for change within the prison.

However, inmates' capacity to promote meaningful prison reform activity is quite limited. Prison systems rely on regimentation, surveillance, and ritualized degradation to maintain order and control. ${ }^{164}$ Even though the strict disciplinary control that traditionally characterized prisons has been tempered in a number of systems, many prison systems continue to function based on the old organizational structure. This approach deprives inmates of any formal institutional power. Inmates are systematically and ceremonially stripped of their status upon entry into the prison. Organized prison reform activities are strongly discouraged, and in many institutions, prohibited. ${ }^{165}$

Inmates cannot respond to unacceptable or brutal treatment by seeking services elsewhere, nor can they directly sanction their keep-

violence to maintain order, force inmates to work, and maintain their power. See $\mathrm{L}$. YACKLE, supra note 51, at 80 . The prison situation thus provides a telling example of how power derives from the capacity to create uncertainty and disruption; $c f . M$. Crozier, supra note 24, at 109-10 (describing analogous symbiotic power relationships in industrial bureaucracies).

161 See supra note 44-58, 109-20 and accompanying text. Thus, for example, although the prison directors in the Texas system recognized the trustee system as a dangerous and violent method of prisoner management and considered eliminating the trustee system, they decided to maintain it because they concluded that "these inmate intermediaries were a crucial source of intelligence and helped to maintain control." B. Crouch \& J. Marquart, supra note 29, at 91.

162 See Toch, supra note 33, at 69; see also Officers Recapture New Mexico Prison Without Resistance, N. Y. Times, Feb. 4, 1980, at A1, col. 2 ("Prison officials made public 11 demands by inmates, ... among them less crowding, better food, improved recreational and education facilities, a halt to 'harassment' and no retaliation for the uprising.").

163 See, e.g., J. JACOBS, supra note 29, at 39 (detailing the accomplishments of advocacy groups on behalf of prisoners).

164 See B. Crouch \& J. Marquart, supra note 29, at 65-66; E. Goffman, supra note 25 , at 14, 18; C. Silberman, supra note 33, at 395; Cloward, supra note 75, at ?? 78-79.

165 The Supreme Court upheld prison officials' prohibition of inmates' organizing activities in Jones v. North Carolina Prisoners' Union, 433 U.S. 119 (1977). 
ers for brutality. ${ }^{166}$ Prison systems are established and mandated by law. The state holds a monopoly on the provision of services, and there is little concern that the institution's existence will be threatened by inadequate service delivery. ${ }^{167}$

There are also serious limitations to disruption and violence as means of transforming prison conditions. It is true that violence often attracts immediate attention and gives inmates a platform for airing their grievances to the public. ${ }^{168}$ Inmate violence, however, tends to reinforce the image of inmates as unworthy and uncontrollable, thus providing a justification for the use of repressive measures to maintain control. ${ }^{169}$ Inmates are likely to get attention, but it may not be the kind they want. They have little control over the response to disruption. In fact, using violence as power tends to reinforce the primacy of order over humanity in the prison. Violence tends to perpetuate the cycle of prison reform by leading to more repressive control measures exercised in the name of restoring order. ${ }^{170}$

Inmates' power to influence outsiders, other than the court, to

166 See, e.g., M. LIPSKY, supra note 25, at 54-56 (because non-voluntary clients can neither avoid nor withdraw from encounters with workers, they have a reduced capacity to discipline street-level bureaucrats and little bargaining power). Indeed, inmates can neither leave the institution nor, in the absence of litigation, express their dissatisfaction directly to management, thus leaving prisoners without either the "exit" or "voice" options identified by Albert Hirschman as mechanisms for recuperation in Exit, Voice and Loyalty. See A. Hirschman, Exit, VoIce and Loyalty 34 (1970).

167 The current interest in privatizing aspects of prison administration is not likely to pose a serious threat to the state's monopoly. Privatization has generated substantial controversy over its legality and morality. It has not yet been widely adopted, and where it has it has been largely restricted to transitional institutions, minimum security facilities, or discrete aspects of service delivery, such as medical care. See generally Symposium: Prizatization of Prisons, 40 VAND. L. Rev. (May 1987); Note, Making Prisons Private: An Improper Delegation of a Governmental Power, 15 Hofstra L. Rev. 649 (1987); Note, The Panopticon Revisited: The Problem of Monitoring Private Prisons, 96 Yale L.J. 353 (1986).

168 This attention is frequently short-lived. See, e.g., L. YACKLE, supra note 51, at 46-47 (describing short-lived public attention in response to a violent uprising in an Alabama penitentiary). Inmates also run the risk that their attempts at disruption will be promptly contained and severely sanctioned without public exposure of their agenda.

169 See, e.g., J. IRwIN, supra note 25, at 140-41 (noting that after the Attica riot, administrators who believed in custody displaced those who believed in treatment).

170 See, e.g., id. at 144 (discussing the hostile reaction of townspeople towards the Attica inmates); J. JACOBS, supra note 25, at 25 (lock-up following riots was a tradition at Stateville in times of crisis); L. YACKLE, supra note 51, at 47 (noting that official response to inmate violence was to arm penal authorities in kind); B. Chilton, supra note 90 , at 92 (in response to violence, state appropriated funds to be used on increasing security). 
take action to change existing conditions is also limited. Until recently, inmates' access to the outside world was quite limited, ${ }^{171}$ and even today, prison officials try to minimize inmates' access to lawyers, legislators, and the media. ${ }^{172}$ Moreover, inmates as a group lack substantial political power. In many states they are not allowed to vote, even after they have completed their sentence and returned to the community. ${ }^{173}$ Many prisoners come from groups that already suffer from political powerlessness-people of color and the poor. ${ }^{174}$ Inmates' families are not a viable source of external pressure, in part because of their low socio-economic status and their reluctance to be publicly linked with the criminal justice system. In addition, inmates suffer from a credibility problem; individuals convicted of a crime are not considered reliable sources of information, particularly when their self-interest is concerned. ${ }^{175}$

Treatment staff are similarly constrained by their institutional position. Counselors lack formal power within the prison system. In most systems they are simply appended to the existing organizational hierarchy and are thus outside the control and decisionmaking structures. ${ }^{176}$ They depend on guards for inmate movement and on the administration for all policy decisions. They have little access to information about either day-to-day conditions or policy. ${ }^{177}$ Unlike guards and inmates, their potential for disruption is limited because

171 See, e.g., B. Crouch \& J. Marquart, supra note 29, at 60 ("Texas prison officials enjoyed great autonomy when it came to controlling inmates . . . due to the prison system's geographic, political and legal isolation.").

172 See, e.g., B. Crouch \& J. Marquart, supra note 29, at 123 (describing how prison officials viewed all writ writers as trouble makers and transferred them to limit their activity); J. JACOBS, supra note 25, at 122 (describing how prison staff resisted the intrusion of a legal services program).

I73 The Supreme Court has upheld state laws permanently disenfranchising felons. See Richardson v. Ramirez, 418 U.S. 24 (1974) (upholding state laws disenfranchising ex-felons); see also J. JACOBS, supra note 29, at 27-28 (discussing challenges to felon disenfranchisement laws); Goldberg \& Marsh, Ex-Offenders Find Doors Closed on Voting Rights, 3 NaT'L Prison Project J. 3 (Spring 1985).

174 See J. JACOBS, supra note 29, at 61; Austin \& Krisberg, supra note 150, at 16.

175 See L. YACKLE, supra note 51, at 81.

176 Counselors and professional staff often are placed under the supervisory control of custodial staff. See, e.g., L. YACKLE, supra note 51, at 139 (noting that the personnel responsible for classification reported to a line officer, resulting in the subversion of classification to security concerns). Professional staff are often isolated from the chain of command so that they have little or no contact with or input into internal decisionmaking. See, e.g., J. JACOBS, supra note 25, at 97 (discussing a "lack of concrete line authority").

177 See, e.g., J. JAcoBs, supra note 25, at 99 ("The individual counselor still remained outside of the central chain of command and without 'professional' duties and responsibilities."). 
their duties lie outside the primary value system of the organization and its participants. Thus, they are unlikely to have the capacity to play a significant role in redirecting prison practices and programs.

Thus, those who pursue change lack the power to influence those whose cooperation and support are necessary to transform prison conditions and practices. Opponents of change are well-situated to thwart the efforts of internal advocates for reform. The absence of a viable political constituency for prison reform, coupled with public ambivalence or antipathy toward inmates, further limit the power of internal prison reformers.

\section{Judicial Intervention and Organizational Stasis}

Court intervention takes place in the context of the dynamics of organizational stasis. Because prison systems lack the normative framework, incentive systems, information mechanisms, and power structure to achieve institutional self-correction, the court's capacity to resolve the remedial dilernma depends upon the court's ability to alter these dynamics underlying organizational stasis. Part II of this Article discusses the institutional attributes that enable courts to bring about effective reform and the strategies that courts use to manage the remedial process.

\section{A. Courts' Institutional Potential to Unlock Organizational Stasis}

Courts are equipped to alter and reform each of the four factors underlying organizational stasis and thereby institute meaningful reform. The court is an external source of normative authority ${ }^{178}$ that is insulated from the direct political pressures that pervade the prison dynamic. ${ }^{179}$ The court has the power to affect conduct by distributing both formal and informal rewards and sanctions to the

178 The term "norms" refers here to both principles of right action binding on members of a group and to particular authoritative standards imposed to institutionalize proper behavior. Courts are authoritative both in the sense that it is a judicial function to declare norms and that they have access to the power of the state to enforce those norms.

179 The federal judiciary's political insulation derives chiefly from the constitutional grant of life tenure to federal judges. See U.S. CoNST. art. III. Of course, federal judges are not completely insulated from political pressures that may limit their role as protectors of ccnstitutional norms. Adverse publicity and social ostracism may accompany judicial actions taken on behalf of inmates, as well as other unpopular groups. See generally J. Peltason, FifTy Eight Lonely MEN (1961). District court judges may be personally affected by these pressures, and unwilling to undertake unpopular or controversial action in the face of them. 
prison system's participants. ${ }^{180}$ By using this power the court can alter the prison's incentive system and thereby encourage change. Active judicial oversight and intervention can foster the development of both new channels of information and expertise within the prison system. The court can employ various information gathering mechanisms to create a common factual base from which to proceed. ${ }^{181}$ Because judicial pronouncements are public and highly visible, they expose prison conditions to public scrutiny. ${ }^{182}$ Finally, by using its formal and informal power to promote change, the court can shift the power balance within the prison system to enable responsible participants to bring about change. The court has the authority and power to induce the prison system's various participants to assume responsibility for institutional reform. ${ }^{183}$ Nevertheless, each of the

180 The potential of the court to influence power relations affecting the institution at issue raises questions about the proper role of the court. If the court acts as a "power broker," that role arguably threatens the court's legitimacy by undermining its conception as neutral, passive, and objective. See Diver, supra note 5 , at 88-105. Although there is merit to this concern, several factors justify proceeding to evaluate the court's capacity to influence the power dynamics of prison systems. First, the linkage of passivity and judicial legitimacy has become more attenuated as litigation grows more complex and multifaceted. See Fiss, supra note 3, at 6-16; Resnik, Managerial Judges, 96 Harv. L. REv. 374, 376-80 (1982). The ideal of passivity conflicts with the demands and realities of much modern day litigation. See id. Nor is it clear that passivity is a positive judicial value regardless of the context of the judiçial activity. This Article shows that in the prison context, judicial passivity results in three delegitimizing consequences for the court: (1) toleration of ongoing violations, (2) judicial role definition in response to the conduct of political actors, and (3) failure to institutionalize legal norms. Second, the dramatic failure of the political process in the area of prisons, which is likely to continue given the dynamics of organizational stasis, provides an argument, at least in theory, supporting judicial alteration of the balance of power. See Diver, supra note 5, at 92-93; cf. Cover, The Origins of Judicial Activism in the Protection of Minorities, 91 YALE L.J. 1287, 1291-92 (1982) (justifying an activist judicial role to protect rights that are vulnerable to "perversions by the majoritarian process"). Finally, this Article proceeds from the premise that impact can be divorced from role definition, and that the court's positive political impact may be the greatest when it performs a more traditional, less political role. See infra text accompanying notes 410-20.

181 The use of special masters, monitors and experts expands the court's information gathering capacity, along with defendants' obligations to report regularly to the court. See Note, supra note 84, at 1072; Special Project, supra note 3, at 826-37. The criticisms of courts' information gathering capacity, while not entirely unfounded, often fail to take into account the availability of these mechanisms. See, e.g., D. Horowitz, supra note 5, at 1-67. One interesting question, which is the subject of a forthcoming article, is the extent to which courts' fact-finding role at the remedial stage can and should differ from its role in adjudicating cases.

182 Prison cases tend to receive extensive media coverage. See, e.g., M.K. Harris \& D. SPILLER, supra note 17 , at 9,84 (noting that extensive coverage of prison overcrowding cases was vital to arousing strong public concern).

183 See infra notes $333-40 \& 426-28$ and accompanying text. 
factors of organizational stasis has the potential to neutralize or divert judicially initiated change.

\section{B. A Typology of Judicial Approaches to the Remedial Process}

The approach adopted to manage the compliance process directly affects a court's capacity to alter the underlying dynamics of organizational stasis. Each judge responsible for developing a remedy for unconstitutional prison conditions and practices necessarily chooses how to formulate relief, who will participate in this process, what incentives should be used to induce the cooperation of necessary parties, how to monitor compliance, and how to deal with the noncompliance of prison officials. ${ }^{184}$ These choices must be made from among a variety options and techniques. Generally, the choices made by a particular court reflect the presiding judge's underlying ideological approach to judicial intervention.

A review of the choices actually made by trial judges in a wide range of prison cases reveals four basic strategic approaches to the remedial process: (1) the deferrer, (2) the director, ${ }^{185}$ (3) the broker, and (4) the catalyst. ${ }^{186}$ Distinct and coherent philosophies underlie and unify the different managerial styles and inform the choice of methods made by the judge in the course of the remedial process. Each approach reflects a set of assumptions and theories about prisons and prison management, institutional reform, the propriety and

184 See generally Special Project, supra note 3, at 790-843 (describing stages of remedial process). Judges are not always aware of the range of options available for each of these decisions, or even that they are making a choice. One of the purposes of this Article is to demonstrate that judges necessarily make choices among different approaches that may have a dramatic impact on their effectiveness, and thus to enhance the awareness of judges and participants in the remedial process of the importance of self-consciously structuring the judicial role.

185 The term "director" as used in this Article refers to the judicial approach identified here and explored below. This term is not to be confused with prison directors - the executive officials responsible for managing the prison system. These officials are referred to as "administrators" or "managers."

186 These four remedial approaches emerged from several sources: (1) an analysis of data obtained by tracing the progress of reported prison cases; (2) reviewing numerous case studies documenting the judicial approaches adopted in particular prison cases; (3) participating in the process of defining the judicial role as part of the office of Special Master in Palmigiano v. Garrahy, 443 F. Supp. 956 (D.R.I. 1977); (4) serving as law clerk to Judge Charles E. Stewart in Powell v. Ward, $487 \mathrm{~F}$. Supp. 917 (S.D.N.Y. 1980); modified, 643 F.2d 924 (2d Cir. 1981), cert. denied, 454 U.S. 832 (1981); (5) conducting a study of the role of special masters in five prison cases, culminating in a Note entitled 'Mastering' Intervention in Prisons, supra note 84; and (6) engaging in numerous interviews and discussions with lawyers, judges, administrators and masters concerning the nature of the judicial role. 
proper extent of the judicial role, and the nature of organizational response to intervention. ${ }^{187}$

This typology of judicial approaches-deferrer, director, broker, and catalyst-provides a framework for organizing, analyzing, and evaluating judicial intervention. Judges do not necessarily recognize and make explicit the managerial strategy they employ. ${ }^{188}$ Furthermore these styles rarely appear in their pure form; a judge will frequently utilize more than one approach or change her approach at different points in the process. ${ }^{189}$ The four models constitute the range of strategies adopted by courts in prison cases. It is necessary to identify the basic attributes and the underlying ideology of each model before analyzing and comparing the efficacy of each of the four models.

\section{The Deferrer}

The deferrer entrusts the defendants with the responsibility for the remedial process. Typically, she orders the defendants to develop a remedy and, in some instances, report to the court about the plans formulated in response to this order. ${ }^{190}$ The court relies on the defendants to take the steps necessary to achieve compliance. Responsibility for monitoring compliance is left to the parties. The court becomes involved in the compliance process only in response

187 The factors which most typically affect a court's decision about adoption of a particular managerial style include: (I) the judge's current view of the nature and limitations of the court's role and the legitimacy of actively intervening in the management of a state institution, both in principle and in the eyes of the anticipated appellate reviewer; (2) the judge's view of the underlying causes of the unconstitutional prison conditions and her expectations of prison officials' response to the judicial mandate; (3) the judge's view of the nature of prison as an institution, and the role and capacity of prison management; (4) a re-evaluation of the assumptions underlying previous judicial strategies in light of experience, or in response to the court's frustration or dissatisfaction with the institution's failure to comply with the constitutional norm.

188 Indeed, I argue that lack of awareness of the managerial choices available in the remedial process impedes the court's capacity to resolve the remedial dilemma.

189 See infra text accompanying notes 244-46.

190 There are degrees of deference in remedy formulation. The most extreme form of deference consists of simply ordering the defendants to eliminate the offending conditions and practices with no guidance as to the remedy. This strategy does occur, although it is not common. A more usual approach is to specify areas of concern that must be addressed by the defendants, or to offer general guidelines to be followed by the defendants in developing and implementing the remedy. See, e.g., Knop v. Johnson, 667 F. Supp. 467, 484, 496 (W.D. Mich. 1987) (setting forth guidelines for submission of plan by defendants), appeal dismissed, stay denied, 841 F.2d 1126 (6th Cir. 1988) Grubbs v. Bradley, 552 F. Supp. 1052, 1125-32 (M.D. Tenn. 1982) (same). 
to specific complaints by the parties. The court responds to noncompliance by reaffirming the defendants' constitutional duties and affording them additional time to comply. ${ }^{191}$ This approach is quite common, particularly in the early stages of the remedial process.

The deferrer's managerial style is informed by a passive and noninterventionist conception of the court's role in prison reform. The structure of judges' daily experience and their faith in the judiciary's normative and symbolic power predispose them to believe that orders will be respected and. followed simply because they emanate from a court. ${ }^{192}$ The deferrer maintains that prison officials should retain exclusive responsibility and control over the prison. ${ }^{193}$ She perceives prison administrators as experts whose judgments should not be second-guessed by a court. The deferrer is also anxious to avoid a confrontation between the federal court and state executive officials.

Instrumental concerns may also account for the court's adoption of the deferrer approach. The court may believe that any other approach will alienate the defendants and thereby undermine attempts to obtain the defendants' cooperation. ${ }^{194}$ Some courts justify deference as the best way to co-opt prison officials into the remedial process. ${ }^{195}$ Finally, a court may simply be disinclined to become entangled in the complexities of a more active role. The judge may be discouraged by the political unpopularity of inmates or of an activist judiciary. She may be tired of the case after a long trial. ${ }^{196} \mathrm{~A}$

191 See, e.g., Palmigiano v. DiPrete, 700 F. Supp. 1180, 1184-86 (D.R.I. 1988) (describing delays, repeated requests for extensions, and modifications of order by court in response); Palmigiano v. Garrahy, Nos. 74-172 \& 75-032 slip op. at 2-4 (D.R.I. Jan. 4, 1982) (same).

192 See, e.g., M.K. HaRris \& D. SpILLER, supra note 17, at 90 (the district court had an "expectation that the defendants would comply with all of the court orders").

193 In Holt v. Sarver, 300 F. Supp. 825 (E.D. Ark. 1969), the judge viewed the court's most important contribution as "bring[ing the] problems to the attention of the public and let[ting] the public administrators do their jobs. . . . In the final analysis, the state had to reform its own institutions." M.K. Harris \& D. SpILler, supra note 17 , at 88 . Deferrers may also believe that noncompliance is the result of factors beyond the control of the prison officials, and thus an inappropriate basis for greater judicial response. See Diver, supra note 5, at 100.

194 See, e.g., M.K. HARRIS \& D. SpILLER, supra note 17, at 88-89 (discussing how in Holt $v$. Sarver the judge believed that to ensure compliance it was essential that the public and public administrators have a receptive attitude toward any judicial decrees and therefore framed general, non-specific, and moderate orders to minimize antagonisms).

195 See, e.g., id.

196 See, e.g., Knowles, Monitoring Committee on Prisons in Alabama Folds; Court Gives Up Jurisdiction, 20 NAT'L PrISON Project J. 1, 7 (Summer 1989) (implementation 
deferrer may fear that any other course of action would invite reversal on appeal. ${ }^{197}$

A prime example of the deferrer approach to remedial intervention is Holt $v$. Sarver. ${ }^{198}$ After finding massive and systemic constitutional violations, ${ }^{199}$ the judge assigned the defendants full responsibility for decree formulation. ${ }^{200}$ The court mandated general improvements in prison conditions and ordered the defendants to prepare a plan for formulating and implementing the remedy. The court never scrutinized or incorporated this plan into a court order. ${ }^{201}$ The court did not become actively involved in monitoring or responding to the defendants' noncompliance. It dismissed a motion for contempt without a hearing and continued to rely upon general orders, reporting requirements, and exhortations even in the face of continuing noncompliance. ${ }^{202}$ The case was characterized by a "conspicuous absence of enforcement mechanisms."203

\section{The Director}

The director judge assumes direct responsibility for developing and implementing the remedy. She formulates a remedy, either on

Committee wished to terminate its involvement in part because its members "all were burned out on the case").

197 In at least several circuits, the appellate courts have articulated standards for reviewing remedial decisions that increase the likelihood that the trial courts will adopt the deferrer approach. See, e.g., Kendrick v. Bland, 740 F.2d 432, 440 (6th Cir. 1984) (district court should impose the least intrusive remedy available); Ruiz v. Estelle, 679 F.2d 1115, 1145 (5th Cir. 1982) (stating that the "relief ordered ... must be 'consistent with the policy of minimum intrusion. . . .' Conservative treatment is essential because it is more readily administered, less costly to the state, and not irreversible. Therefore, the remedy should begin with what is absolutely necessary. If these measures later prove ineffective, more stringent ones should be considered." (quoting Ruiz v. Estelle, 650 F.2d 555, 571 (5th Cir. 1981))), modified, 688 F.2d 266 (5th Cir. 1982), cert. denied, 460 U.S. 1042 (1983). The role of appellate courts in institutional reform litigation is critical to the process of defining a proper and effective approach to court intervention in institutional reform cases, and is the subject of a forthcoming article.

198309 F. Supp. 362 (E.D. Ark. 1970). This and other examples are used only to illustrate the models. As noted above, a court will rarely adopt only the techniques characteristic of one model. See infra notes 244-46 and accompanying text.

199 See Holt, 309 F. Supp. at 372-81.

200 See M.K. Harris \& D. SpIller, supra note 17, at 12.

201 See Holt, 309 F. Supp. at 383. The court simply ordered the defendants to "make a prompt and reasonable start toward eliminating the [unconstitutional] conditions." The court orders for the most part remained general and flexible, tracking the pleading and the general requirements to eliminate unconstitutional conditions. See M.K. HARRIS \& D. SPILLER, supra note 17, at 89.

202 See M.K. HaRris \& D. SPILLER, supra note 17, at 106.

203 See id. at 105. 
her own or with the aid of the plaintiffs' counsel or a court-appointed expert, and imposes it on the defendants. ${ }^{204}$ If additional resources or expertise are needed to implement particular programs, the director undertakes to obtain them, and may bring in outsiders to perform necessary work. The director works directly with those parties whose cooperation is needed to implement the decree. ${ }^{205}$ Monitoring compliance becomes part. of the task of administering the decree. The director responds to a defendant's noncompliance or noncooperation by assuming greater control over the implementation of the decree. She increases the specificity of its orders to reduce the probability of evasion and to enhance its control. ${ }^{206}$ The director attempts to alter conduct within the prison by assuming direct responsibility for administering particular provisions of the decree $^{207}$ or seeking to transfer or fire those who subvert compliance efforts. ${ }^{208}$ She may require the defendants to use court appointed

204 See, e.g., Palmigiano v. Garrahy, 443 F. Supp. 956 (D.R.I. 1977) (judge imposes detailed remedy); Pugh v. Locke, 406 F. Supp. 318 (M.D. Ala. 1976) (judge issued detailed remedy); Hamilton v. Schiro, 338 F.Supp. 1016 (E.D. La. 1970) (judge issues detailed findings of unconstitutional conditions; master formulates relief).

205 In Georgia, the judge met privately with the governor to work out compliance plans. See B. Chilton, supra note 90 , at 99 . In Alabama, Judge Johnson met with key legislators to facilitate their cooperation with the court order. See L. YACKLE, supra note 51, at 41 .

206 See, e.g., M.K. HARRIS \& D. SPILlER, supra note 17, at 68-69 (concluding that court responded to noncompliance by ordering the special master to develop specific plans, which were then adopted by the court). The director may also use increased control over the remedy as a means of inducing the defendants to assume responsibility for the compliance process. See, e.g., L. YACKLE, supra note 51, at 17 (telling how Judge Johnson established his own prescriptive standards to convince the defendants that he was serious about compliance). However, by assuming greater control, the court may in fact create a situation in which the defendants will contest the court's authority, evade or ignore the court's order, or abdicate responsibility entirely. See infra notis $278-300$ and accompanying text.

207 See, e.g., Knop v. Johnson, 685 F. Supp. 636, 640 (W.D. Mich. 1988) (court mandated particular disciplinary actions in the event racially derogatory conduct occurred); Harris v. Pernsley, No. 82-1847, slip op. at (E.D. Pa. Nov. 23, 1987) (ordering the creation of a "[b]ailcare program); L. YACKLE, supra note 51, at 103-04 (noting that the court ordered creation of a Human Rights Committee with fairly broad powers "to 'monitor implementation' of the standards fixed by [its] order").

208 The director may attempt informally to achieve the discharge of officials frustrating the compliance effort. See, e.g., L. YACKLE, supra note 51, at 118 (asserting that the Chair of the Human Rights Committee met with the Lieutenant Governor, representatives of the Governor, key legislators, and the Board of Corrections, to urge that the Commissioner be fired and replaced by a more able administrator). In Alabama, the commissioner also ordered the discharge of hold-over officers from a prior administration. See id. at 189. 
agents to carry out specific provisions of the order..$^{209}$ The director approach is particularly common at the decree formulation stage, and as a follow-up to the deferrer approach to implementation. ${ }^{210}$

The conception of the judicial role underlying the director approach is activist and managerial. Directors believe that a court's constitutional and equitable duty to intervene effectively in response to executive and legislative failure to fulfill their constitutional responsibilities justifies an expansive, managerial approach. ${ }^{211}$ The director perceives that the responsible officials cannot or will not undertake meaningful compliance activity on their own-a view that may derive from defendants' conduct at trial or the court's prior experience with the relevant officials. ${ }^{212}$ The quickest and easiest way to achieve compliance, then, is for the court to go in, do what needs to be done, and get out. The director is confident that the court has the capacity to formulate and implement effective solutions to the problems causing unconstitutional prison conditions. Instead of promoting the internal development of reform mechanisms within the prison community, the director assumes responsibility for some or all of the implementation process.

Judge Johnson's approach to the remedial process in Pugh $v$. Locke ${ }^{213}$ exemplifies the director approach. After an extensive trial on the issue of liability, Judge Johnson issued an order setting forth detailed requirements touching on the conditions of daily life in the

209 See, e.g., id. at 103-04 (discussing order in Pugh that Board of Governors contract with the Center for Correctional Psychology to undertake revamping of classification system and reclassification of inmates, and power of oversight committee to hire "independent specialists" to aid compliance).

210 See, e.g., Knop, 685 F. Supp. at 640 ("'[T]he prison administrators have demonstrated their unwillingness or inability to deal with this problem in a realistic, firm manner. The Court has no alternative, given this situation, but to usurp some measure of the defendants' discretion as administrators in order to insure that the constitutional violation is remedied."). When the deferrer approach proved unsatisfactory, the court appointed a special master to formulate relief and adopted the Master's Report and Recommendations in Hamilton v. Landrieu, 351 F. Supp. 549 (E.D. La. 1972). See M.K. Harris \& D. SPILlER, supra note 17, at 13.

211 See, e.g., Johnson, The Constitution and the Federal District Judge, 54 TEx. L. REv. 903,905 (1976) (arguing that courts must act where the legislature or appointed officials do not).

212 See, e.g., L. YACKLE, supra note 51, at 101 (noting that in Pugh v. Locke, 406 F. Supp. 318 (M.D. Ala. 1976), Judge Johnson. "had reached the conclusion that the state authorities would not respond readily and must, therefore, be given explicit commands. ... He held state authorities to a series of specific directions, most of which touched on the conditions of daily life in the prisons.").

213406 F. Supp. 318 (M.D. Ala. 1976), aff'd sub nom. Newman v. Alabama, 559 F.2d 283 (1977), rev'd in part and remanded sub nom. Alabama v. Pugh, 438 U.S. 781 (1978) (per curiam). 
prisons. ${ }^{214}$ The order was developed unilaterally by the court, without significant input from the parties, and relied on evidence obtained at the trial on the merits. ${ }^{215}$ The court undertook to enforce compliance by appointing a 39-member Human Rights Committee with the authority to "take any action reasonably necessary to accomplish its function," 216 increasing the specificity of its orders, and, in particular areas, assuming direct control over implementation. For example, the court ordered the state to contract out responsibility for reclassifying inmates to the Center for Correctional Psychology, a program selected by the court. ${ }^{217}$ The court declined to utilize contempt sanctions, damages awards, or release of inmates in order to coerce the defendants into compliance, instead responding by modifying its orders to increase their specificity and appointing the Governor of Alabama as receiver of the prison system. ${ }^{218}$

\section{The Broker}

The broker uses informal judicial power, exercised primarily through counsel, to engineer agreements among the parties and induce remedial action by the defendants. ${ }^{219}$ She formulates the remedy by working with counsel to encourage, and if necessary coerce, the parties to reach agreement. ${ }^{220}$ The broker rejects formal

214 See L. YACKLE, supra note 51, at 101-02.

215 See id. at 101-04.

216 Pugh, 406 F. Supp. at 332. The Court of Appeals found that the Human Rights Committee "impermissibly intrude[d]" into the daily operation of the prison. See Newman v $v_{3}$ Alabama, 559 F.2d 283, 289 (5th Cir. 1977), rev'd in part on other grounds and remanded sub nom. Alabarna v. Pugh, 438 U.S. 781 (1978) (per curiam).

21 7 See L. YAcKLE, supra note 51, at 139-40, 146.

218 See id. at 183-84; Knowles, supra note 196, at 2.

219 The broker approach is not intended to exemplify the range of possible approaches to settlement. However, there is a marked and dramatic tendency among courts involved in developing institutional remedies, at least in prison litigation, to rely on counsel to negotiate agreements within the framework of the adversary process employed during the liability phase. Thus, counsel are the primary participants, and the focus is on the legal result, rather than the participants or process by which it was reached. The prevalence and significance of this approach warrants its treatment as a separate judicial strategy. The catalyst differs from the broker in that it focuses on the nature of the process rather than the achievement of agreement, it directly involves the participants in the institution, and it backs up its process with the use of formal judicial sanctions. See infra text accompanying notes 230-43.

220 See, e.g., Collins v. Schoonfield, 344 F. Supp. 257, 285 (D. Md. 1972) (court required counsel for both sides to meet and try to reach agreement on a remedial order); M.K. HaRris \& D. SpIller, supra note 17, at 12 (noting a number of cases, including Collins, in which the court has acted as a broker). 
sanctions and instead exerts pressure through its informal bargaining power. ${ }^{221}$ She establishes guidelines, offers informal suggestions to encourage acquiescence, publicly praises compliance efforts, and threatens the imposition of sanctions or more intrusive remedies in the event of noncompliance. ${ }^{222}$ The broker strives to achieve a compromise if the parties reach an impasse by serving as an intermediary between counsel and encouraging the parties to moderate their demands. ${ }^{223}$ The court rejects formal monitoring techniques such as hearings because of their tendency to polarize the parties.

The broker values voluntarism and consent as a means of producing a fair result that the defendants will accept. She focuses primarily on inducing the parties to agree to the terms of the remedy. The processes by which the decree is formulated, the participation of the parties responsible for implementation and the substantive outcome of the negotiations are secondary to the goal of achieving agreement. The broker functions within and has faith in the effectiveness of the adjudicatory framework, relying primarily on counsel to the parties to negotiate disputes and communicate the results to the court and the parties.

The broker's emphasis on negotiated agreement reflects an underlying ideology valuing the minimization of the extent to which the court intrudes on the decisionmaking processes of the prison. The broker treats the remedial process as a series of ongoing disputes between the parties. The broker is typically uncomfortable with a more activist role and seeks to avoid the drain on judicial resources that often accompanies a more activist approach. ${ }^{224}$ Like

221 See, e.g., M.K. Harris \& D. SPILlER, supra note 17, at 197 (noting that in Holland v. Donelon, No. 71-1442 (E.D. La. May 16, 1972), "the judge took a moderate approach in [response] to compliance failures ... regard[ing] sanctions such as finding the defendants in contempt of court to be very drastic and wish[ing] to avoid [the use of] such sanctions"); id. at 393 (stating that in Collins, "[t]he court used informal pressure and positive reinforcement in contrast to punitive enforcement devices").

222 See, e.g., id. at 12 (noting that in Collins, "[t]he judge played a strong role in the process by exerting pressure on both sides to moderate and compromise."); id. at 197-98 (discussing Holland, where Judge Rubin used informal action, including conferences, informal rebukes, and reviewing the order line-by-line with members of parish council to ensure that they knew their obligations); Judge: R.I. Must Act on Prison Crowding, Providence J. Bull., December 16, 1988, at 1, col. 1 (reporting that a federal judge threatened the state with contempt if the state missed the deadline for submitting the remedial plan or failed to implement the plan).

223 See, e.g., M.K. HARris \& D. SPILlER, supra note 17, at 12 (stating that the judge in Collins played a strong role in formulation, exerting pressure on both sides to moderate and compromise).

224 See, e.g., L. YACKLE, supra note 51, at 193 (Judge Varner was disinclined to 
the deferrer, the broker may believe that voluntary cooperation is a prerequisite to compliance and that a less intrusive approach is the only way to induce the defendants' participation. ${ }^{225}$

The broker approach to remedial intervention was employed in Collins $v$. Schoonfield. ${ }^{226}$ In Collins, the judge required counsel for both sides to meet and try to reach agreement on an order. ${ }^{227}$ The primary parties played a minimal role in the negotiations. The judge "played a strong role in the process by exerting pressure on both sides to moderate and cornpromise." 228 He left the process of implementing the agreement largely to the parties, intervening primarily at the request of plaintiffs' counsel to threaten or cajole defendants to live up to the terms of their agreement. ${ }^{229}$

\section{The Catalyst}

The catalyst creates processes and incentives in order to induce the parties to participate in a deliberative process to formulate and implement an effective remedy. The judge employs a two-prong approach combining a deliberative remedial formulation process with the use of traditional sanctions to induce the necessary parties to participate. The responsible parties must identify the conditions causing the constitutional violation, gather information and expertise required to formulate an effective remedy, ${ }^{230}$ and involve the actors essential to successful reform. ${ }^{231}$ The catalyst evaluates the

challenge the lawyers when their efforts allowed him "to escape a time-consuming evidentiary hearing.").

225 As this Article argues below, the broker's emphasis on the outcome of the process and reliance on lawyers as the primary participants in the remedial stage undercuts the effectiveness of the broker approach as a means of "coopting" the defendants into the compliance process. See infra text accompanying note 313-16.

226344 F. Supp. 257 (D. Md. 1972).

227 See M.K. HARRIS \& D. SPILlER, supra note 17 , at 12.

$228 I d$.

229 See id. at 365, 393 (after issuing two "interim decrees," court only issued subsequent relief at suggestion of counsel for both sides; monitoring performed primarily by counsel for plaintiffs .... The court used informal pressure and positive reinforcement in contrast to punitive enforcement devices.").

230 See, e.g., Spear v. Ariyoshi, No. 84-1 104, Consent Decree at 3 (D. Haw. June 12,1985 ) ("Defendants and plaintiffs shall agree upon a panel of experts for each of the substantive areas covered in this Decree. Each panel shall consist of a representative of the Division of Corrections, and two experts who are designated by the parties. The panel shall study the issues and develop specific implementation plans for the various substantive areas set forth in . . . this Decree . . . "); $c f$. Memorandum from Gordon Bonnyman to Co-Counsel, May 14, 1985, at 4 (July order required "coherent analysis and informed planning").

231 In Guthrie v. Evans, No. 73-3068 (S.D. Ga. 1973), the court obtained the parties' agreement to attempt to participate in mediation to produce a compliance 
resulting remedy by assessing both the adequacy of the process by which it was developed and its reasonableness in light of the information gathered. ${ }^{232}$

The court uses its informal power to make resources available and contributes expertise. The court also establishes and adheres to regular deadlines for evaluating compliance progress, and takes steps to obtain the information necessary to monitor compliance. Defendants are required to develop information-gathering systems to inform the compliance process and enable the court to evaluate progress. ${ }^{233}$

The catalyst responds to defendants' noncooperation by using the traditional judicial power of compensating plaintiffs and sanctioning defendants for ongoing violations of the court order. ${ }^{234}$ The catalyst's reaction to noncompliance does not itself institutionalize a constitutional norm. It does, however, reinforce the importance of

plan. The commissioner of corrections, the warden, several inmates, and the assistant attorney general, participated directly in the negotiating process. The general goals of the plan were produced through mediation. The specifics of the plan were developed by the Commissioner and the Department staff and approved by the court. See B. Chilton, supra note 90 , at 77-78.

232 See, e.g., United States v. Michigan, 680 F. Supp. 928, 1056 (W.D. Mich. 1987) (mandating modification of parties' agreement due to its failure to address significant issues identified in the Independent Expert's report). Deliberation operates here as a mechanism for both legitimizing and inculcating norms through participation in their formulation and achieving substantively just results. See Chin \& Benne, supra note 23, at 31-36; cf. Sunstein, Beyond the Republican Revival, 97 YALE L.J. 1539 , 1550 (1988) ("The requirements of deliberation embodies substantive limitations that in some settings lead to vaguely correct outcomes."). This approach leads the court to employ masters, compliance aids, and expert panels to assist in remedy formulation and compliance monitoring. See, e.g., M.K. HARRIS \& D. SPILLER, supra note 17, at 187 (noting that in Holland v. Donelon, No. 71-1442 (E.D. La. May 26,1971 ) the court used a master to work with the sheriff and coroner to develop specific compliance plans).

233 See, e.g., Spear v. Ariyoshi, No. 84-1104, at 13, (D. Haw. Nov. 5, 1985) (mandating the creation of a system-wide management information system and task force to explore the need for it); Grubbs v. Pellegrin, Nos. 80-3404, 80-3518, 80$3616,80-3617$, Order at 3 (M.D. Tenn. Oct. 18, 1983) (ordering defendants to gather and provide information to the court concerning the prison population level).

234 See, e.g., Michigan, 680 F. Supp. at 1053 (holding defendants in contempt for failing to implement overcrowding and classification plan, with opportunity to purge themselves of contempt and avoid fines of $\$ 10,000$ a day by complying with the Consent Decree); id. at 1047 (enjoining prison from receiving any new inmates for five day period); L. YACKLE, supra note 51, at 171 (noting that Judge Pointer, in Wyatt v. Walker, Civ. Action No. 76-P-0775-W (N.D. Ala.) and in Thomas v. Gloor, Civ. Action No. 77-P66-S (N.D. Ala. ), "held local and state officials in contempt for failing to comply with his orders ....", levied fines for noncompliance, and required part of the money exacted in Birmingham to be paid directly to the prisoners affected). 
the constitutional norm and the defendants' responsibility for achieving it. Thus, the catalyst's approach reflects both the boundaries of judicial power and the importance of utilizing that power to induce the prison officials to act. ${ }^{235}$ The court combines externally imposed pressure with internally organized response to induce the defendants to institute the required changes.

The catalyst approach is process-oriented, and its underlying philosophy of the judicial role is one of structured or bounded activism. The court employs its information-gathering tools and traditional sanctions to force responsible officials to take the constitutional standards seriously and induce them to perform. The catalyst therefore focuses on inducing prison officials to change their conduct through the development of resources and expertise, channels for participation, and the use of traditional sanctions.

The catalyst believes that prison officials will remain unable or unwilling to initiate meaningful compliance in the absence of a strong judicial presence during the remedial implementation stage. ${ }^{236}$ Nevertheless, the catalyst has limited confidence in the court's capacity to manage change directly. In the view of the catalyst, noncompliance with prison decrees is no different than similar

235 The use of sanctions and awarding of damages to plaintiffs conflicts with the judicial orientations of the three other models of remedial intervention and is therefore not part of the normal repertoire of the deferrer, director or broker. The deferrer eschews sanctions due to their intrusiveness on prison officials and is unwilling to attribute failure to and impose sanctions on prison officials for noncompliance. See supra notes 191-97 and accompanying text. The director views contempt as inappropriate or ineffective because of prison officials' incompetence or resistance to meaningful compliance activity. See supra notes 206-13 and accompanying text. The broker views contempt as counter-productive because of its tendency to polarize the defendants and undermine their cooperation. The broker also shares the view that the imposition of sanctions intrudes on defendants' autonomy. See supra notes $219-25$ and accompanying text. Judges may also believe that it is unfair to impose sanctions or award damages because noncompliance is at least in part caused by factors beyond defendants' control, or that the problems underlying noncompliance are too complex and political to warrant sanctions. By refusing to use the traditional judicial tools available to enforce their decrees, the deferrer, director, and broker relinquish the tools often needed to induce prison officials to take court intervention seriously and assume responsibility for institutional change. Arguably, by failing to treat prison officials' noncompliance in the same manner as violations of "ordinary" court orders, the court is inappropriately acting on "political" concerns. By so departing from its proper judicial role the court undermines its effectiveness and legitimacy.

236 See, e.g., Palmigiano v. DiPrete, 700 F. Supp. 1180, 1185 (D.R.I. 1988) (" " $[\mathrm{T}]$ he pattern is always the same: without monitoring, prison officials permitted the kitchen to get into a deplorable state ... they failed to provide adequate medical staff for an increase in population of which they have been aware for years" " (quoting Palmigiano v. Garrahy, 639 F. Supp. 244, 258 (D.R.I. 1986))). 
resistance in less controversial cases, and protection of the court's authority requires enforcement of its mandate. ${ }^{237}$

Judge Spaeth's strategy in the early stages of Jackson v. Hendrick $^{238}$ is an example of the catalyst approach. In Jackson, the court rejected the plaintiffs' request for unilateral imposition of specific relief and instead appointed a special master to work with the responsible parties to fashion a systemic remedy. ${ }^{239}$ Consent decrees were entered covering the range of constitutional violations identified at trial. ${ }^{240}$ The master was also retained to facilitate the compliance effort and report to the court on the defendants' progress. The City defendants then failed to comply with several important provisions of the decree. Rather than assuming direct control or attempting to cajole the City into compliance, the court responded "by holding the defendants in contempt of court and fining the City $\$ 325,000$."241

The consent decree issued in Spear $v$. Ariyosha ${ }^{242}$ further illustrates the catalyst approach. In Spear, the parties negotiated a settlement prior to trial that incorporates the catalyst approach to remedy formulation. The decree identified a series of problem areas and established a set of performance standards to be addressed through the remedy formulation process. The decree also set up three panels, each including an expert nominated by the plaintiffs, one nominated by the defendants, and a member of the division of corrections. The panels were given ninety days to develop a plan in consultation with members of the prison system and outside experts. Disagreements between the experts or the parties were to be submitted for mediation prior to resolution by the court. Once the remedy was formulated, the expert panels assumed responsibility for inspecting the facilities and reporting on the plan's implementation. ${ }^{243}$

237 See, e.g., Knowles, supra note 196, at 4 (conservative judge who assumed responsibility for Pugh v. Locke "was willing to be more forceful in attempting to force compliance with the court's orders than Judge Johnson had been").

$238457 \mathrm{~Pa} .405,321$ A.2d 603 (1974). Judge Spaeth's involvement in the case ended when he left the bench and the federal court assumed active supervision of the overcrowding aspect of the case. See Harris v. Pernsley, 755 F.2d 338 (3d Cir.), cert. denied, 474 U.S. 965 (1985).

239 See Jackson, $457 \mathrm{~Pa}$. at 406, $321 \mathrm{~A} .2 \mathrm{~d}$ at 604 (affirming order appointing master to formulate remedial plan); Rudovsky, Litigating Prison Conditions in Philadelphia, 1 The Prison J. 64, 68 (1985).

240 See Rudovsky, supra note 239 , at 68 .

241 Id.

242 No. 84-1104 (D. Haw. June 12, 1985).

243 See id. Consent Decree at 11-13; Janger, Expert Negotiation Brings New Approach 


\section{Combining Judicial Approaches}

This description of the four judicial approaches to formulating and implementing remedies presents each as a pure model, followed throughout the litigation. However, in many cases judges use a combination of strategies through the course of the litigation. ${ }^{244}$ A court may appoint a master or other compliance official who employs an approach different from that of the judge. ${ }^{245}$ Judges also may tailor their approach to the type of issue before the court. For example, many judges who are reluctant to use the director approach generally will dictate and implement specific relief in the areas of due process and law libraries-areas in which the court may perceive itself to have special expertise. Similarly, areas the court believes require professional expertise beyond the defendants' capacity, such as medical care, have been singled out for the director or catalyst approach. Finally, in areas that pose an imminent threat to inmates' safety or survival, courts otherwise reluctant to assume an activist role have employed the director or catalyst approach.

This typology affords a iramework for assessing each approach, whether employed in its pure form or in combination with other

to Prison Litigation in Hawaii, 6 NAT'L Prison Project J. 6, 7 (Winter 1985); McClymont, Hard-Fought Settlement Reached in Hawaii Case, 5 NAT'L Prison Project J. 3,4 (Fall 1985). A variation on the catalyst approach to implementation was adopted in the New York City jail litigation. See Lasker, Prison Litigation: Many Years Toward Compliance, 11 Nat'l Prison Project J. 9, 10 (Spring 1987) (describing the Office of Compliance Consultants, appointed in Rhem v. Malcolm, 507 F.2d 333 (2d Cir. 1974), as compliance monitors, consisting of a director "experienced in corrections matters but unrelated to the parties, and a small staff of Corrections Department personnel on leave. OCC deals wilh compliance on an item by item basis, making suggestions to the parties, mediating and conciliating between them, and reporting at regular intervals to the court on the particulars of compliance and the rate of progress.").

244 See, e.g., Palmigiano v. Garrahy, 443 F. Supp. 956 (D.R.I. 1977) (using all four approaches), aff'd, 616 F.2d 598 (1st Cir. 1980), cert. denied, 449 U.S. 839 (1980); Ney, Judge Bans Further Intake of Prisoners at D.C. Jail, 5 NAT'L Prison Project J. 6, 7 (Fall 1985) (quoting court order prohibiting further intake of prisoners in Campbell v. McGruder, No. 71-1462, at 50 (D.D.C. July 15, 1985) (memorandum and order) stating: "[t]ime and again, defendants have requested the court to defer to their accumulated wisdom, to stay its hand, and to give them more time. Time and again, these requests have been honored in the hope and expectation that defendants would solve these problems expeditiously and effectively. However, instead of matters improving, they have deteriorated.").

245 See, e.g., Grubbs v. Bradley, 552 F. Supp. 1052 (M.D. Tenn. 1982) (exemplifying court as deferrer, master as catalyst); L. YACKLE, supra note 51, at 110 (stating that Judge Johnson established the Human Relations Committee with the hope that it would form a cooperative relationship with the prison authorities and act as a catalyst, preventing the need for further direct intervention by the court). 
approaches, based on its relative capacity to influence the norms, incentives, information exchange, and power structure within the prison so that meaningful change can occur. ${ }^{246}$

\section{The Impact of the Strategies of Judicial Intervention on the Factors Underlying Organizational Stasis}

A court's capacity to unlock the dynamics of organizational stasis in the prison depends on the particular strategy it adopts for formulating and implementing the remedy. ${ }^{247}$ Part III of this Article analyzes each strategy in terms of its capacity to affect the four factors that contribute to organizational stasis-norms, incentives, information exchange, and power.

\section{A. The Court's Capacity to Institute a Competing Normative Framework}

One aspect of the dynamic contributing to unconstitutional prison conditions is the absence of an internal normative framework supporting reform. Judicial intervention can introduce and legitimize the competing norm of promoting and protecting individual dignity. ${ }^{248}$ The very determination of liability signifies that the

246 It may be useful to visualize the analysis that follows in relation to the following matrix:

Norms

$$
\text { Deferrer Director Broker Catalyst }
$$

Incentives

Information

Power

247 This is not to say that the judicial approach is the only constraint affecting the court's potential impact, or even the most significant factor in a particular case. Other factors, such as the political environment, the skill and influence of counsel, and the management ability of those responsible for prison conditions are likely to come into play, and may in fact influence the approach adopted by the court. See, e.g., P. Cooper, Hard Judicial Choices 233-36 (1988). However, this Article focuses only on the potential impact of the judicial strategy adopted by the court.

248 See, e.g., M.K. Harris \& D. SPILlER, supra note 17, at 312 (noting that a particular prison reform lawsuit was said to have "elevated status of prisoners and caused prison personnel to treat them with dignity and respect"). Evidence suggests that at least a core group of corrections administrators has internalized the constitutional norms and is pursuing strategies for achieving progressive reform. For example, a group of corrections commissioners currently participates in a Program of Correctional Leadership and Innovation supported by the Wharton Center for Applied Research and the Edna McConnell Clark Foundation. See T. Gilmore, Program on Correctional Leadership and Innovation: Introduction to Program Strategy (August 1985) (unpublished paper) (on file with the University of Pennsylvania Law Review). 
prison's normative framework is unacceptable. ${ }^{249}$ Prison officials must conform to a normative perspective that respects the inviolability of certain basic needs and rights, even in pursuit of the legitimate goals of order, efficiency, and security.

The authoritative pronouncement of norms that differ from those currently dominating the prison can legitimize the goals and values of those actors committed to change. The judicial prohibition of practices that deprive inmates of their rights elevates inmates' status within the institution. Reform advocates legitimately may claim that inmates' needs must be treated as organizational imperatives.

The determination of liability and the court's subsequent pronouncements challenge the internal norm of preserving the status quo by acknowledging that change is imperative regardless of its potential for disruption. ${ }^{250}$ The normative framework introduced and enforced by the court prevents the prison administration from resorting to the traditional means of maintaining order within the prison. ${ }^{251}$ Unless the defendants are willing to abandon the organizational goals of order and efficiency, those charged with administering the prison must formulate new methods of maintaining order consistent with the norm of promoting individual dignity. ${ }^{252}$ The

249 See supra note 16-18 and accompanying text for a review of the constitutional standards.

250 The assault on the existing normative structure often leads to the resignation or removal of officials most committed to maintaining it. A dramatic example of this phenomenon occurred in Texas during the early 1980s where there was a tremendous turnover at both the administrative and staff level following the issuance of special master's report concerning the illegal maintenance of the trusty system. A new commissioner was brought in from the outside, and did not share the commitment to the control structure represented by the trusty system. The new guards had not been schooled in the desirability or inevitability of the trusty system. According to the special master, the new regime is now as opposed to the trusty system as the old regime was committed to it. See Telephone interview with Vincent Nathan (Dec. 26, 1988); see, e.g., B. CRouch \& J. MARQUART, supra note 29, at 226-229 (describing the changeover in staff attitudes).

251 See supra note 31 . Courts prohibit the use of violence, either officially or unofficially, to maintain day-to-day control. See, e.g., Jackson v. Bishop, 404 F.2d 571, 579 (8th Cir. 1968) (holding that whipping as a disciplinary measure violates the eighth amendment). Threats of uncertain, summary, and harsh punishment are no longer available as control mechanisms. Privileges that were reserved for those inmates who aided the maintenance of order in the prison will be equally available to all inmates. In many jurisdictions, courts will proscribe the utilization of inmate trusties to maintain order. See, e.g., Ruiz v. Estelle, 679 F.2d 1115, 1177-79 (5th Cir. 1982) (listing district court's order on impermissible inmate conduct and privileges), modified, 688 F.2d 266 (5th Cir.), cert. denied, 460 U.S. 1042 (1985); Holt v. Sarver, 309 F. Supp. 362, 365, 383-84 (E.D. Ark. 1970) (holding trustee system as administered violated eighth amendment), aff'd, 442 F.2d 258 (8th Cir. 1971).

252 Some commentators have linked court intervention, as well as any effort to 
court can stimulate the implementation of progressive methods of managing inmates to replace the old methods no longer available to prison administrators. Moreover, by attracting attention and resources to the prison problem and creating incentives for prison officials to end judicial oversight, the court may foster the internal development of professional norms and standards. ${ }^{253}$ Consequently, judicial intervention can create conditions that force prison officials to respond affirmatively to meet the organizational goal of order. $^{254}$

Judicial intervention also limits society's capacity to delegate total responsibility for the conditions of imprisonment to administrative officials. Most court proceedings and rulings are open to the public and frequently receive extensive media coverage. ${ }^{255}$ By exposing prison conditions to public scrutiny, courts encourage prison officials, politicians, and the public to engage in a dialogue about prison conditions, purposes, and practices. ${ }^{256}$ This dialogue compels prison officials to consider and accommodate values exter-

institute major change in the prison system, with at least a short term increase in violence within the prison system. See, e.g., J. Dilulio, Governing Prisons: A Comparative Study of Correctional Management 219, 226, 229 (1987) (detailing surge of violence in Texas prisons); Engel \& Rothman, Prison Violence and the Paradox of Reform, The Public Interest 91, 94, 100-101 (Fall 1983) (linking increased violence to prison reforms). But these studies "generally fail to establish a causal chain between court decisions and the alleged consequences of those decisions." $M$. Feeley \& R. Hanson, What We Know, Think We Know and Would Like to Know About the Impact of Court Orders on Prison Conditions and Jail Crowding 29 (unpublished paper prepared for a meeting of the Working Group on Jail and Prison Crowding) (on file with the University of Pennsylvania Law Review). Others have strongly disagreed with the opinion that judicial intervention inevitably leads to violence. See S. Martin \& S. EkLand-Olson, supra note 158, at xix; V. Nathan, Reflections on Two Decades of Court Ordered Prison Reform 42-48 (unpublished speech) (transcript on file with the Universily of Pennsylvania Law Review) (attributing a rise in violence to the prison administration's hostile response to judicial intervention). Researchers have observed that destabilization may be a transitional state, leading to the development of new methods of maintaining order. See B. Crouch \& J. Marquart, supra note 29, at 215-16, 227-29.

253 See e.g, L. YACKLE, supra note 51, at 27 (discussing prison officials' adoption of new substantive standards to avoid litigation and judicial intervention). The special master in the Texas prison litigation reported that the prison officials who previously were committed to the view that the trustee system was necessary and inevitable came to hold the opposite view with equal commitment. See Telephone interview with Vincent Nathan (Dec. 26, 1988).

254 See, e.g., Hepburn, supra note 40, at 57 (concluding that guard work attitudes improve when collaborative or participative management is employed).

255 See, e.g., L. YACKLE, supra note 51, at 45.

256 See M.K. Harris \& D. SPILler, supra note 17, at 26; L. YACKLE, supra note 51, at 66-68; Special Project, supra note 38, at 528. 
nal to those characterizing the dynamics of organizational stasis when formulating prison policy and practice.

The process of formulating and implementing the remedy can encourage prison officials to question the existing normative structure and to develop new approaches that maintain both individual dignity and institutional order. ${ }^{257}$ Each of the four judicial approaches employs a different strategy whereby courts can introduce a new normative standard to the prison.

\section{The Deferrer and the Limits of Reliance on the Existing Normative System}

The deferrer introduces the court's competing normative framework by declaring that the existing prison conditions are unconstitutional and ordering the prison administrators to change prison policies and practices to conform with the constitutional mandate. The court delegates the responsibility of translating the broad directive into a specific plan to the named defendants-usually the director and the wardens-and their attorneys. ${ }^{258}$ The deferrer relies on the prison administration to communicate the judicially mandated normative shift to the various participants in the prison system.

The deferrer's capacity to influence the normative perspective of those within the prison system is limited. The court delegates the task of norm development and promulgation to those whose normative perspective is determined by the demands of maintaining order within the prison. ${ }^{259}$ Many of those charged with contextualizing the constitutional norm will attempt to tailor it to the existing normative

257 See, e.g., J. Baiamonte, The Need for a Systemic Policy Approach to Jail Overcrowding: A Case Study of Jefferson Parish, Louisiana, 1971-1987 (unpublished paper) (on file with the University of Pennsylvania Law Review) (detailing the adoption of a systemic approach to jail overcrowding involving the warden, criminal justice coordinating council, district attorney, pre-trial release services, state judiciary, and bail system, in response to Holland v. Donelon, No. 71-1442 (E.D. La. May 16, 1972)); supra notes 243.

258 See Holt v. Sarver, 309 F. Supp. 362, 385 (E.D. Ark. 1970), aff'd, 442 F.2d 804 (8th Cir. 1971). Contrast this approach to the one taken in the same case for developing a remedy to deal with the medical program. The court required the defendants to bring in experts to study the system and come up with specific recommendations for improvements, which were then incorporated into a court order. See Third Supplemental Decree, cited in M.K. Harris \& D. SPILler, supra note 17, at 99. Thus, in specific areas where the court perceived the need for expertise, the court deviated from its general deferrer approach and adopted the director approach to remedy formulation. See supra text accompanying notes 245-46.

259 See supra notes $43-58 \& 109-20$ and accompanying text. 
perspective within the prison. This minimizes the likelihood of provoking any serious deliberation about acceptable prison practices.

The deferrer's commitment to the preservation of administrative independence reinforces the norm of maintaining internal autonomy within the prison system and affords key actors enough latitude to vitiate the remedy's impact. Even those prison officials who might share the court's substantive critique of prison conditions and practices may resist the introduction of norms from outside the prison system. ${ }^{260}$ Defendants may actively resist judicial involvement by delaying their response, refusing to respond, or openly challenging the court's authority and legitimacy. ${ }^{261}$ Specifically, defendants may ignore the existence of the court order or fail to inform lower level workens of its mandate. ${ }^{262}$ They may deliberately undermine court-order changes by promulgating them with a wink and a nod. ${ }^{263}$ Or, they may engage in passive resistance by translating the broad constitutional directives into superficial or unmeasurable changes that minimize judicial involvement or impact. ${ }^{264}$ These administrative responses mirror those of line

260 See Kimball \& Newman, Judicial Intervention in Correctional Decisions: Threat and Response, 14 CRIME \& Deline. 1, 7-9 (1968); Rubin, The Administrative Response to Court Decisions, 15 Crime \& Deline. 377, $377-79$ (1969); Special Project, supra note 38, at 530; see also M.K. HARRIS \& D. SpILler, supra note 17, at 93 (discussing reformminded prison commissioner's expression of resentment toward court's continued intervention in Arkansas).

261 See, e.g., Palmigiano v. DiPrete, 700 F. Supp. 1180, 1190 (D.R.I. 1988) (“At virtually every point in the long history of this case, the Department has relied on the complexity of the problems, which this Court has never denied, as an excuse to plead for more time. Yet despite this Court's generosity in being responsive to these pleas, year after year has passed and still the Department has failed to make convincing efforts to implement viable solutions."), aff'd, 887 F.2d 258 (1st Cir. 1989); V. Nathan, supra note 252, at 45 ("The signals of obstruction and predictions of ultimate vindication emanating from departmental headquarters ... reached wardens and their institutional subordinates, as well as inmates, ... through television sets and radios reporting defiant statements and hostile reactions by TDC's leadership ....").

262 See, e.g., Powell v. Ward, 487 F. Supp. 917, 924-32 (S.D.N.Y. 1980) (recounting prison official's attempts to circumvent or ignore the court order), aff'd, 643 F.2d 924 (2d Cir.), modified, 643 F.2d 924 (2d Cir.), cert. denied, 454 U.S. 832 (1981); M.K. HARRIS \& D.SPILlER, supra note 17, at 103 (asserting that in Finney v. Arkansas Bd. of Corrections, 505 F.2d 194 (8th Cir. 1974), the administrators did not routinely inform departmental employees of the substance of court orders and explain their impact on daily job performance, or inform employees of their responsibility to comply with the orders); id. at 159 (discussing the ignorance of some management staff in Jefferson Parish Prison of a court order limiting the prison population).

263 See, e.g., B. Crouch \& J. Marquart, supra note 29, at 131-33 (describing how prison officials undermined norm condemning guard brutality by refusing to discipline and subsequently promoting guards who brutalized inmates).

264 See, e.g., M.K. HARRIS \& D. SpILlER, supra note 17, at 71-72 (noting that the 
workers resisting reform directives of prison administrators. ${ }^{265}$ As long as court orders remain broad and ambiguous, defendants can easily evade compliance. ${ }^{266}$

The deferrer strategy affords little or no opportunity for the court to affect the normative perspective of those not directly accountable to the court. Within the prison, the court relies on prison officials for dissemination of its normative vision. Yet the dynamics of the prison limit the administrators capacity to communicate effectively with subordinates and mobilize the corrections bureaucracy. ${ }^{267}$ The prison bureaucracy, and guards especially, often views the court's intervention as naive, biased, and illegitimate. ${ }^{268}$ Furthermore, if the court is perceived by inmates and counselors as deferring to the prison administration, inmates may become disillusioned with the court, yiewing it as part of the system that oppresses them rather than as a vehicle for change. ${ }^{269}$ The deferrer does nothing to reduce the predictable opposition of legislators, governors, and parole board members to a change in normative perspective, stemming from the increased additional responsibilities, costs, and political risks accompanying such change. ${ }^{270}$ The deferrer thus fails to alter the existing organizational dynamic.

By delegating to the defendants the task of introducing the con-

commissioner of the Arkansas prison system eliminated armed "trustee" guards with unarmed "floor walker" guards who continued to perform many of the same functions); L. YACKLE, supra note 51, at 209-10 (describing the Attorney General's proposed plan to deal with the overcrowding problem by shuffling prisoners back and forth between jails and prisons so that no inmate would be forced to spend more than a few months in crowded jail); Alexander, supra note 51, at 968 (discussing the creation of substitute procedures by administrators that accomplish the same result as procedures invalidated by the court).

265 See note 43 and accompanying text.

266 See, e.g., M.K. HaRris \& D. SPILlER, supra note 17, at 97 (noting that the plaintiffs' attorneys believed that the ambiguous orders in Holt v. Sarver, $309 \mathrm{~F}$. Supp. 362 (E.D. Ark. 1970), were "virtually unenforceable" and that Commissioner Sarver warned that general and non-specific orders "made it possible for unwilling defendants to evade compliance").

267 See supra notes 85-127 and accompanying text; T. Storey, supra note 110 , at 37 (noting that an administrator felt that "one of the primary reasons for DOC's failure to break down resistance was their inability to educate and explain why the changes were good for staff'). This is a problem of judicial intervention generally, which can be minimized by other judicial approaches, particularly the catalyst, but not completely avoided. See infra notes 320-32 and accompanying text.

268 See J. Dilulio, supra note 252, at 219; L. Lombardo, supra note 25, at 78; Special Project, supra note 38, at 497-98, 532-33.

269 See Note, supra note 84 , at 1077 n.80.

270 See supra notes 144-53 and accompanying text. See, e.g., M.K. Harris \& D. SPILler, supra note 17, at 97 (noting that in Holt v. Sarver, 309 F. Supp. 362 (E.D. Ark. 1970), when the Commissioner attempted to justify certain reforms by declaring 
stitutional norm to the prison, the deferrer is caught on one horn of the dilemma. The court embraces the normative perspective of prison autonomy and control that characterizes and preserves the status quo.

\section{The Director: Norm Development Without Internalization}

The director attempts to introduce new norms to the prison system by developing and imposing specific standards and programmatic requirements designed to institutionalize the general normative requirements of the Constitution. ${ }^{271}$ The director assumes direct responsibility for assembling the information necessary to formulate the remedy's particular provisions and for developing the specific terms and requirements of the remedy. ${ }^{272}$

Typically, the director limits or excludes the defendants' participation in the formulation of the remedy's provisions. ${ }^{273}$ Some courts rely exclusively on the trial record as the basis for their plan, and may even announce the order in the same opinion that establishes defendants' liability. ${ }^{274}$ Others will seek additional information, either from the parties or court appointed experts. ${ }^{275}$ The court may adopt provisions used by courts in other litigation or provisions submitted by plaintiffs' counsel. It may also use a courtappointed expert to make recommendations or develop an entire plan concerning the appropriate remedy. ${ }^{276}$ The director may

that the federal court ordered them, legislators responded that the proposed reforms exceeded the court's requirements).

271 See Ruiz v. Estelle, 679 F.2d 1115, 1142 (5th Cir. 1982), modified, 688 F.2d 266 (5th Cir. 1983), cert. denied, 460 U.S. 1042 (1983); B. Crouch \& J. MarQuarT, supra note 29 , at 126 ; L. YACKLE, supra note 51 , at 101 .

272 See, e.g., L. YACKLE, supra note 51, at 101-04 (reporting that the judge formed a commission and ordered it to monitor the prison's compliance with his orders).

273 The court may evolve into a director by initially inviting defendant's participation in the plan formulation process and, when defendants fail to respond adequately, assuming direct control. See, e.g., Knop v. Johnson, 685 F. Supp. 636, 640 (W.D. Mich. 1988) (holding that in response to defendants' unwillingness or inability to deal with racially derogatory conduct "in a realistic, firm manner ... [ $t$ ]he Court has no alternative ... but to usurp some measure of the defendants' discretion as administrators" and mandate particular disciplinary actions).

274 See, e.g., L. YACKLE, supra note 51, at 20 (noting that Judge Johnson took evidence not only to establish relevant facts but to establish a basis for remedial order).

275 See, e.g., Costello v. Wainwright, 397 F. Supp. 20, 23 (M.D. Fla. 1975) (appointing a panel of medical doctors to conduct comprehensive study of health services in all correctional institutions in Florida and to report their findings to the court and to recommend appropriate remedial measures), aff'd, $525 \mathrm{~F} .2 \mathrm{~d} 1239$ (5th Cir. 1976).

276 See, e.g., M.K. HARris \& D. SpIller, supra note 17, at 253 (noting that the 
obtain information and hear objections from the defendants concerning proposed relief, but this tends to be the full extent of the defendant's participation. The final order is the product of judicial decisionmaking concerning the nature of the problems causing unconstitutional conditions and the appropriate remedy to eliminate those illegalities. ${ }^{277}$

Although the director avoids repeating the deferrer's failure to introduce any new normative framework, the court is nevertheless caught by the remedial dilemma inherent in institutional reform. Norms developed and introduced by the court are likely to be resisted or neutralized by those who bear responsibility for incorporating them into their practices. ${ }^{278}$ The director bypasses the prison system's ordinary lines of authority, introducing uncertainty, reducing institutional autonomy, and disrupting the orderly functioning of the system's strict organizational hierarchy. ${ }^{279}$ The director thus challenges the basic norms and incentives of the organizational dynamic. ${ }^{280}$ In the view of many insiders, the court is not a legitimate participant in the dialogue about prison conditions ${ }^{281}$-only those who have experienced the daily reality of the prison understand its exigencies. The court is likely to be viewed as a naive out-

court in Hamilton v. Schiro, 338 F. Supp. 1016 (E.D. La. 1972) responded to defendants' noncompliance with general order to remedy unconstitutional conditions by appointing special master to formulate "a detailed workable plan for the correction of the conditions found by him to exist at Orleans Parish Prison").

277 See, e.g., id. at 292-93 (discussing a master who formulated the remedy for the court by talking to inmates, staff and officials, and consulting with experts, but whose final report was based on his personal judgment concerning the appropriate remedy).

278 See supra notes $113-16$ \& 137-43 and accompanying text; see also L. YACKLE, supra note 51, at 105-06 (recalling that Governor Wallace and other politicians were dedicated to resisting the court order). Prison officials are less likely to resist the imposition of court-ordered requirements that do not challenge the control structure or impinge on their day-to-day activities, particularly if the changes require additional outside resources. See E3. Crouch \& J. Marquart, supra note 29, at 128 (noting that defendants consented to requirements in areas of overcrowding and medical care but fought court intervention in areas of discipline and inmate trustees).

279 See Special Project, supra note 38, at 497-501; supra notes 204-212 and accompanying text.

280 See supra notes $28-65 \&$ 82-120 and accompanying text.

281 See, e.g., B. Crouch \& J. Marquart, supra note 29, at 128 (describing how the prison authorities thought that the judge was a meddling "bleeding heart" "convict lover" who imposed frivolous remedies that invaded the state's rights). By imposing detailed normative standards on the prison, the director frequently generates media coverage about the legitimacy of the court's role, rather than the need for administrative or legislative action. For example, in Alabama the media responded to Judge Johnson's order by criticizing the order and the judge's actions for being intrusive and favorable to inmates. See L. YACKLE, supra note 51, at 104-05. 
sider all too willing to accept the inmate's view of the prison and impose unrealistic and disruptive demands for change. ${ }^{282}$ Judicial intervention thus is perceived as threatening and illegitimate, and resistance to court orders is considered appropriate and desirable. ${ }^{283}$

The perception of illegitimacy is intensified if the prison participants believe that the court lacks a principled basis for adopting a particular program. Because defendants do not participate in formulating the remedy under the director approach, they do not develop the understanding, acceptance, or commitment that may emerge from a deliberative, participatory process of remedial formulation. ${ }^{284}$ The court frequently fails to explain the basis for a particular provision or the process by which a particular provision is formulated. In the absence of an articulated approach, a process that takes into account the concerns of the prison officials, or a legal principle requiring the adoption of a particular remedy, the director appears to impose her personal preference on the prison. ${ }^{285}$

Norms that are perceived to be unprincipled, disruptive, or illegitimate are not likely to be incorporated into the prison routine or the general policymaking process. ${ }^{286}$ Indeed, these norms are likely to be ignored, ${ }^{287}$ or to provoke formal resistance through the appeals process ${ }^{288}$ and informal sabotage by conveying to those

282 See Special Project, supra note 38, at 519; see also Delulio, Prison Discipline and Prison Reforn, 89 Pub. InTERest 71, 82 (Fall 1987) (quoting Commissioner Estelle as stating that "what these people knew about prisons you could fit into a tiny thimble with room to spare. ... [We] would not be part of simple-minded so-called reforms that ... were bound to kill inmates, injure staff and destroy our programs").

283 See, e.g., Champagne, The Theory of Limited Judicial Impact: Reforming the Dallas Jail as a Case Study, in The Political Science of Criminal Justice 87, 91 (S. Nagel, E. Fairchild, \& A. Champagne eds. 1983) (noting that the most influential politicians in Dallas County justified a policy of inaction because they felt the voters would not approve " "building a country club for these prisoners" ").

284 See Special Project, supra note 38, at 499; cf. Diver, supra note 5, at 90 ("Virtually all organizational theorists stipulate as one condition for successful change the participation of those whose behavior must be altered.").

285 See Note, supra note 84, at 1083 n.109.

286 See, e.g., M.K. HARRIS \& D. SPILlER, supra note 17, at 288 (discussing how in Hamilton v. Schiro, 338 F. Supp. 1016 (E.D. La 1970), the defendants' belief that certain orders were neither feasible nor desirable affected the level of compliance).

287 See, e.g., id. at 188 (suggesting that the defendants in Holland v. Donelon, No. 71-1442 (E.D. La. May 16, 1972) failed to take seriously the orders formulated by the court); id. at 301 (noting that the sheriff never read the special master's final report and was not familiar with the specific provisions of final decree, and that if the sheriff's priorities conflicted with provisions of the decree he simply ignored them).

288 See, e.g., L. YACKLE, supra note 51, at 129-30 (noting that Governor Wallace vowed to resist the court order through the appellate review). The court is frequently 
within the system a sense of the invalidity of the court's program. ${ }^{289}$ The remedy's provisions may be narrowly interpreted and formalistically applied ${ }^{290}$ by simply blending them into existing practice. ${ }^{291}$

reluctant to take any significant acrion during the pendency of the appeal. See, e.g., id. at 137 (noting that the judge told attorneys from both sides that he would take no action while the appeal was pending); see also B. CROUCH \& J. MARQUART, supra note 29 , at 128 (discussing resistance to mandated changes in control practices through informal noncooperation and formal appeals).

289 See, e.g., L. YACKLE, supra note 51, at 105 (Governor Wallace publicly condemned Judge Johnson's prison decree, announced his intention to resist by appealing, and hinted that he would refuse to comply).

290 See, e.g., M.K. HARRIS \& D. SpIller, supra note 17, at 261 (recounting that when in Hamilton v. Schiro, $338 \mathrm{~F}$. Supp. 1016 (E.D. La. 1972), the court adopted a plan unilaterally formulated by the special master that mandated the creation of a department of detention and correction, the city effected "[a] temporary and superficial form of compliance" by hiring a penologist for a year, giving him no authority with regard to the prison, and failing to replace him after he left the position); id. at 269-70 (describing how prison officials circumvented due process requirements by instituting an "aclministrative" sanction of "banning"-the "loss of institutional privileges without a simultaneous change of residence or classification"- -which was imposed on a residential unit by the administrative staff).

291 See id. at 176 (noting that the sheriff responded to a recommendation to hire a qualified classification officer by appointing a deputy sheriff with no relevant experience or education "interim" classification officer; the sheriff in fact hired a penologist and reported that he had hired a qualified classification officer and never filled the position with a permanent appointment).

The saga of a court's attempt to use an outside organization to implement a classification system in Alabama, recounted in Reform and Regret, provides a vivid example of the limited ability of the court unilaterally to effect change. See L. YACKLE, supra note 51, at 137-67. The court ordered the defendants to contract with the Center for Correctional Psychology ("CCP") to implement a new classification plan and placed the head of the CCP in charge of the classification effort. The CCP obtained financial and administrative support and set up the Prison Classification Project ("PCP') to undertake the reclassification effort.

The prison authorities insisted that they were capable of classifying prisoners without interference from the outside and resisted the efforts of CCP. They involved counsel in meetings intended to develop the classification system, which gave the meetings an "adversary flavor" and magnified mutual suspicions. See id. at 143, 150. State authorities refused to act on PCP's classification decisions. See id at 157. The prison official responsible for classification repeatedly challenged the decisions and actions of the PCP. He refused to make his staff available to work with PCP. The prison officials filed objections with the court concerning PCP's classification decisions in an extraordinarily large percentage of the cases. See id. at 158-59. Many of these objections, which were overruled by the court, were based on fundamental differences between PCP and the Department concerning the criteria for classification. See id. at 159.

PCP developed new procedures and criteria for classification and reclassified all inmates in the Alabama system. 'The court then terminated PCP's involvement in Alabama's prisons. A year after PCP's departure, an expert reviewed the classification programs in Alabama's major prisons. He found that the rules and procedures instituted by PCP were no longer in use. "There was ... little trace of the work that [PCP] had done .... The prison system's omnipresent bureaucracy, with 
The prison administration can undercut even those provisions that leave no room for interpretation by developing alternative procedures that neutralize the impact of the court's mandate. ${ }^{292}$

The director strategy may frustrate the developmental process indispensable to the formulation and implementation of the appropriate remedy in a particular prison. In some cases, an effective solution can be developed only through the joint deliberation of responsible decisionmakers, relevant experts, and prison participants. ${ }^{293}$ Systemic problems, such as overcrowding, often require the participation of outside policymakers. ${ }^{294}$ Moreover, it is in part through exposure to different approaches and programs that individuals change their perceptions of what works, what is possible, and what is acceptable. ${ }^{295}$ Historically, the absence of this type of exchange has characterized decisionmaking in the corrections con-

its own norms and practices, closed in to fill the hole left by PCP and, very shortly, eliminated all evidence that the intruders had ever come." Id. at 164-65.

292 See, e.g., Special Project, supra note 38, at 531-32 (describing efforts by prison officials to avoid the effects of an order concerning the provision of legal assistance by imposing restrictions limiting the prisoners' access to counsel); Plaintiffs' Memorandum in Opposition to Defendants' Motion for Relief from Order and in Support of Motion to Hold Defendants in Contempt at 14-15, Grubbs v. Norris, 870 F.2d 343 (6th Cir. 1989) (Nos. 80-3404, 80-3616, 80-3617) (describing defendants' "subterfuges designed to make their population appear lower than it was in fact" by adjusting furloughs and temporary transfers of inmates so that they would be gone on the last day of the month when population was counted). The capacity to neutralize the effect of specific remedial provisions imposed by the court will depend, of course, on the nature of the problem at issue. Some remedial issues, such as those requiring specific changes in physical facilities, will leave little room for maneuvering by prison officials. Reforms that require the participation of prison officials for their implementation, such as introduction of new programs, procedures or privileges for inmates, leave substantial room for manipulation by prison officials.

293 See supra note 232. This process of norm development may not be necessary for every type of violation that is the subject of judicial intervention. Specifically, the remedy may be obvious where the violation at issue involves discreet practices that inflict immediate and extreme harm and are easily monitored, and for which there is a clearly accepted prohibition and a straight-forward remedial response, such as a negative injunction against the use of strip cells as punishment. In these situations, the delay that inevitably accompanies the deliberative process of remedy formulation may not be warranted or necessary to produce appropriate, effective relief. See, e.g., M.K. Harris \& D. SpILLER, supra note 17, at 69-70 (noting that in Holt v. Sarver, 309 F. Supp. 362 (E.D. Ark. 1970), the court issued specific injunctions against interfering with inmate access to the court and assigning inmates to racially segregated cells); L. YACKLE, supra note 51, at 14, 94-95 (recounting how Judge Johnson ordered Alabama defendants to close the notorious "dog houses" used for punitive confinement and to cease accepting inmates).

294 See supra note $150-56$ and accompanying text.

295 See Chin \& Benne, supra note 23, at 43-48 ("[C]hange . . . will occur only as the persons are brought to change their normative orientations to old patterns and develop commitments to new ones."). 
text and contributed to the intractability of the status quo. The directorial approach does nothing to generate a process to encourage the development of a new normative framework. ${ }^{296}$

The director also risks institutional co-optation. The court assumes direct responsibility for implementation, so its success depends on the attainment of compliance. Overseeing the compliance process, however, is time-consuming, frustrating, and controversial. It thrusts the judge into an unfamiliar and, in many instances, uncomfortable role. Any perceived negative effects of the director's remedy are likely to be attributed to the court's failure. The court therefore has strong incentives to terminate its involvement as quickly as possible. .97

In response to the difficulties of achieving compliance, the director may tailor the relief ordered to the constraints of the judicial role. ${ }^{298}$ The court may relax the requirements set forth in its original order, ${ }^{299}$ or choose programmatic standards and goals that can be measured and easily achieved, regardless of their impact on institutional practice. ${ }^{300}$ Thus, the director is particularly susceptible to a form of goal displacement that limits the court's impact on the normative framework of the prison system.

This problem is exacerbated by the limits of constitutional doctrine. Directors may only inject norms grounded in legal doctrine. $^{301}$ The constitutional prohibition against cruel and unusual

296 A court may use the threat of a unilaterally crafted remedy to create incentives for the defendants or the parties to participate in the remedial process. See supra note 206. This approach of course characterizes the broker. If the parties fail to respond to the threat, the court then adopts the director approach, with the limitations described above.

297 The court may also amend its order in an effort to avoid further appeals. See L. YACKLE, supra note 51, at 130-31 ‘describing how Judge Johnson backed away from strict cell space requirements in an effort to undercut Governor Wallace's appeal of a court order).

298 See, e.g., id. (discussing how Judge Johnson prepared to make changes in the order to accommodate the reservations of an expert).

299 See, e.g., M.K. Harris \& D. SpIller, supra note 17, at 158 (noting that at a hearing on a motion for contempt, the court in Holland v. Donelon, No. 71-1442 (E.D. La. May 16, 1972), increased the population limit from 110 to 132); Note, supra note 84 , at $1081 \mathrm{n} .102$ (" $[\mathrm{C}]$ ourt's solution to racial segregation was to assign beds according to race, allowing Spanish inmates to be treated as 'wild cards' (either black or white)").

300 See, e.g., Note, supra note 84 , at 1081 n.102 (the "[c]ourt's solution to problem of guard brutality was to develop experimental psychological screening test for guards; problem of strained working conditions, inadequate training and hostile relationships with inmates not addressed").

301 Although the legal norm constrains the remedial process under each of the four judicial approaches, the director is particularly limited because the court is 
punishment is essentially a negative doctrine, prohibiting certain practices and conditions, but containing no affirmative normative vision of prison practices. ${ }^{302}$ Constitutional doctrine therefore does not directly mandate the development of norms that promote and protect individual integrity, only the elimination of visible abuses.

The Supreme Court's current approach to determining whether a particular prison condition or practice violates the Constitution further constrains the director's capacity to affect the normative framework of the prison system. The Court's recent opinions emphasize the importance of preserving the discretion of prison officials both in defining the constitutional norm and determining the proper remedy. ${ }^{303} \mathrm{~A}$ majority of the Court appears to endorse prison officials' unlimited mandate to strike the appropriate balance between order and individual dignity. However, this approach fails to take into account the institutional dynamics that prevent prison officials from reasonably assessing the degree to which individual needs must be compromised in the interest of maintaining order. ${ }^{304}$ The Court thus has relinquished to some extent the task of defining the constitutional norm for prisons to a system that cannot effec-

imposing a remedy that derives its authority solely from the legal standard. Under each of the other approaches, the remedial process affords the opportunity to treat the legal norm as the starting point rather than the boundary of the remedial process. The deferrer permits the defendants, in the rare instance that they are capable and willing, to undertake a more systemic approach to the constitutional violation. Similarly, the broker allows the parties to agree to a remedy that exceeds the constitutional norm. See Local No. 93, Int'l Ass'n of Firefighters v. Cleveland, 478 U.S. 501, 525 (1986) ("[A] federal court is not necessarily barred from entering a consent decree merely because the decree provides broader relief than the court could have awarded after a trial."). The catalyst, by structuring a deliberative process, encourages the parties to treat the remedial stage as an opportunity to develop effective strategies for addressing the underlying causes of the legal violation, even if the resulting remedy exceeds the legal standards.

302 In Rhodes v. Chapman, 452 U.S. 337 (1981), the Supreme Court stated:

No static 'test' can exist by which courts determine whether conditions of confinement are cruel and unusual, for the Eighth Amendment "must draw it meaning from the evolving standards of decency that mark the progress of a maturing society"... But conditions that cannot be said to be cruel and unusual under contemporary standards are not unconstitutional. To the extent that such conditions are restrictive and even harsh, they are part of the penalty that criminal offenders pay for their offenses against society.

Id. at 346-47 (quoting Trop v. Dulles, 356 U.S. 86, 101 (1958) (plurality opinion)). 303 See O'Lone v. Estate of Shabazz, 482 U.S. 342, 353 (1987); Bell v. Wolfish, 441 U.S. 520, 547-48 (1979); Jones v. North Carolina Prisoners' Labor Union, 433 U.S. 119, 125 (1977); Pell v. Procunier, 417 U.S. 817, 826-27 (1974).

304 See supra notes 29-55 and accompanying text (describing goal displacement of order by prison officials). 
tively generate a normative framework requiring the prison to incur costs or change its routine in order to protect individual inmates.

The Supreme Court's prison jurisprudence constrains the director's capacity to impose her normative framework upon the prison. ${ }^{305}$ The court's remedy may not exceed the scope of narrowly defined constitutional violations. The court must accept and work within the existing institutional framework and may not unilaterally impose programmatic changes unrelated to the conditions violating the constitution. ${ }^{306}$ Particularly given the Supreme Court's restrictive interpretation of the role of the federal courts in finding unconstitutional prison conditions, ${ }^{307}$ the director's authority is limited because her remedy derives its legitimacy exclusively from the narrow constitutional norm. ${ }^{308}$

The court's limited mandate tends to discourage the exploration of innovative, progressive approaches to eliminating unconstitutional conditions. ${ }^{309}$ The court is predisposed to adopt short-term, conventional approaches that may lock in limited, out-dated, and ultimately ineffective solutions to prison problems. ${ }^{310}$ Because of

305 Thus, the analysis of the dynamics of organizational stasis not only implies that a different approach to prison remedies is needed, but also supports a less permissive substantive standard. This raises the issue of the proper place that remedial inadequacy should have in setting a substantive rule. This question, although extremely important to the question of the court's remedial efficacy, is beyond the scope of this Article.

306 See, e.g., Hoptowit v. Ray, 682 F.2d 1237, 1250-51 (9th Cir. 1982) (finding that the district court went too far in ordering testing, training and various programs for guards); L. YACKLE, supra note 51, at 89 (noting Judge Johnson's unwillingness to second-guess the state's policies of incarcerating inmates in large rural prisons or involving the parole board in the litigation).

307 See, e.g., Block v. Rutherford, 468 U.S. 576 (1981) (holding that in ruling on the constitutionality of pretrial detention facilities, a federal court should play a limited role and, absent substantial evidence establishing constitutional violations, defer to the expertise of corrections officers).

308 See, e.g., Ruiz v. Estelle, 679 F.2d 1115 (5th Cir. 1982) (reversing aspects of Judge Justice's order, inter alia, requiring the state to (1) use paroles and furloughs to reduce overcrowding, (2) only house one inmate in cells that contain sixty square feet or less, and (3) reorganize the management of a prison facility), modified, $688 \mathrm{~F} .2 \mathrm{~d} 266$ (5th Cir.), cert. denied, 460 U.S. 1042 (1983).

309 For example, Judge Johnson in Alabama refused to hear testimony concerning sentencing and parole policy, and rejected the plaintiffs' motion to involve the parole board as a defendant. Instead, he focused his attention almost exclusively on the physical conditions of life in the institutions that already existed. This approach essentially foreclosed more systemic approaches to the problem of overcrowding in Alabama's prisons. See L. YACKLE, supra note 51, at 89.

310 See, e.g., M.K. Harris \& D. SpILler, supra note 17, at 263-64 (concluding that the court order led to a dramatic increase in shakedowns and a drastic reduction of inmate movement within the prison); L. YACKLE, supra note 51, at 102 (stating that the court ordered frequent "shakedowns" as a means of dealing with violence); $i d$. at 
the defendants' tendency to change only to the extent required by the court, these limited judicial standards, intended to be minima below which the prison may not fall, become a ceiling beyond which the prison will not venture. ${ }^{311}$ The director may thereby prevent the development of more humane, effective, and less costly approaches to imprisonment. ${ }^{312}$

Thus, the director's assumption of direct responsibility for norm development fails to resolve the dilemma of remedy formulation and implementation due to the court's limited capacity to institute effective norms without the participation of the prison officials responsible for implementing them.

\section{The Broker and the Limits of the Adversary Process}

The broker's bargaining strategy appears to resolve the remedial dilemma by relying on the lawyers to develop the remedy on behalf of the parties through negotiation. The broker avoids the appearance of illegitimacy and seemingly reduces internal resistance to the new normative framework by grounding its remedial requirements in the parties' consent. At the same time, the broker conveys to the prison administration that the court will not rely exclusively upon those parties responsible for initially creating the unconstitutional conditions.

The broker's strategy, however, is dramatically affected by the limitations of the adversary process. The negotiation of norms primarily by lawyers, ${ }^{313}$ rather than by the prison officials who bear

97 (noting that the population problem was dealt with by imposing a cap, which diverted the problem to local jails, exacerbating conditions there.); id. at 190 (describing the dismay of prisoners' lawyers because their efforts produced only more penitentiaries on the traditional model: "[a] new Governor had proved willing finally to act-but his action had been in precisely the direction the plaintiffs had wished to avoid").

311 For example, in Alabama the state officials responded to the court-ordered population cap and 60 -square-foot space requirement by constructing "human warehouses" as quickly and cheaply as possible, "with no attempt to provide anything beyond the minimum space per prisoner that Judge Johnson's order prescribed." L. YACKLE, supra note 51, at 174-75; see also M.K. Harris \& D. SPILler, supra note 17, at 369-70 (describing how an order prohibiting curtailment of privileges for more than six days without a hearing was used to allow staff to avoid hearings).

312 See, e.g., L. YACKLE, supra note 51, at 98 (noting an argument by a state official that prison officials have responded to court orders by building more prisons, rather than by developing a range of alternative intermediate sanctions).

313 See, e.g., M.K. HaRris \& D. SpILler, supra note 17, at 390 (concluding that "the defendants" attorneys, rather than defendants themselves, were responsible for most of the negotiation and ... input"). 
responsibility for implementing them, ${ }^{314}$ reduces the likelihood that the prison community will internalize those norms. The key actors within the prison often view the remedy's provisions as an externally imposed product developed by lawyers unfamiliar with the special needs of the prison environment. ${ }^{315}$ Prison administrators often convey their lack of commitment to the new normative framework to the prison hierarchy. As a result, the line-workers most responsible for implementing the new normative framework are encouraged to neglect or resist the remedy. ${ }^{316}$

Lawyers' adversarial tendencies further limit the broker's capacity to introduce a new norrnative perspective into the prison. Lawyers frequently adopt extreme positions to enhance their bargaining strength and cut their potential losses. Plaintiffs' counsel is likely to focus on the adoption of specific standards that can be easily monitored. ${ }^{317}$ Defendants' counisel, on the other hand, will concentrate

314 See, e.g., Dickey, The Promise and Problems of Rulemaking in Corrections: The Wisconsin Experience, 1983 WIS. L. REv. 285, 292 (showing that the system for segregating dangerous inmates "was largely the result of the advice of the division's attorneys on what could be defencled in court"). The broker will sometimes attempt to induce agreement by making informal suggestions to the parties concerning particular remedial issues. In some cases, the defendants treat these informal suggestions as the equivalent of court orders. See M.K. Harris \& D. Spiller, supra note 17 , at 67 . Under these circumstances, the mediator approach suffers from the same limitations of the unilateral imposition of norms as the director approach. See supra text accompanying notes 2783-312.

315 See, e.g., Dickey, supra note 314 , at 292 (finding that a Wisconsin correctional system that was devised by attorneys to satisfy a court order "was so impractically elaborate that it was never implernented" (citation omitted)); T. Storey, supra note 110 , at 34 (asserting that the Department of Corrections "never really took the negotiations seriously" in part "because dealing with lawyers and written regulations was foreign to them"). Representation of defendants by the attorney general, rather than by department of corrections' counsel, poses an additional conflict between lawyer and client. The perspective and political interests of the attorney general frequently differ from those of prison officials.

316 See, e.g., M.K. HARRIS \& D. SPILlER, supra note 17, at 387 (noting that staff members involved in Collins v. Schoonfield, 355 F. Supp. 257 (D. Md. 1972), resented court intervention, and, because there were no apparent penalties for noncompliance for staff members, decrees were, in the words of a jail staff member, regarded as " 'just pieces of paper' "); Dickey, supra note 314, at 292 (asserting that inmates thought to be dangerous were found guilty of violations of other disciplinary rules justifying their segregation, thereby circumventing the limitations of the policy developed by the lawyers).

317 See Knowles, supra note 196, at 7; see also M.K. HARRIs \& D. SPILlER, supra note 17 , at 391 (noting that plaintiffs' counsel feared that the defendants would evade or resist compliance by exploiting vague or general relief, and insisted on a high degree of detail and specificity); T. Storey, supra note 110, at 35 (plaintiffs' counsel "was more concerned with creating a binding document which covered as many aspects of inmate conditions as possible"). This concern stems in part from lawyers' general preoccupation with the liability stages of litigation and their relative 
on minimizing the impact of the resulting decree on their clients. ${ }^{318}$ Neither side is predisposed to consider carefully the institutional dynamics of the implementation process, and both sides usually have limited experience with the problems of implementation. ${ }^{319}$

Thus, the broker's reliance on the adversary process to produce a normative agreement limits the possibility of an effective process of norm development. The dilemma remains unresolved.

\section{The Catalyst: Creating a Context for Norm Development}

The catalyst approach to introducing a new normative framework directly addresses the elements contributing to the prison's organizational stasis. The catalyst neither defers to the existing normative framework of the prison system nor unilaterally imposes judicial norms. She does not rely exclusively upon the lawyers to produce an agreement. ${ }^{320}$ Rather, the catalyst structures a process

inattentiveness to the remedial stage. Plaintiff' counsel also tends to distrust the defendants and the court to some extent, and thus often insists on standards that can easily be measured. See Knowles, supra note 196, at 7 .

Plaintiff's counsel may also be affected by limitations on the resources and energy devoted to the remedial stage of the litigation. In addition, counsel's concern about the availability of fees may influence the approach to the bargaining process. These factors may constrain plaintiffs' counsel's ability to bargain effectively.

318 See, e.g., M.K. Harris \& D. SPILler, supra note 17, at 392 (concluding that the defendants tended to focus on exactly what was ordered, rather than on more generalized objectives). Thus, the broker's role in introducing a competing normative perspective may suffer from the same limitations constraining the director-the tendency to create a ceiling above which the defendants will not go. See Dickey, supra note 314, at 291-93.

319 See, e.g., M.K. Harris \& D. SpILler, supra note 17, at 390 (noting that attorneys' "inability to see the forest" contributed to later problems experienced in seeking compliance); Dickey, supra note 314, at 292 (concluding that the system developed on paper was highly problematic); T. Storey, supra note 110 , at 35 (attorneys knew little about problems of implementing provisions of consent decree). Specialized prisoners' rights organizations that have been litigating prison cases for years, such as the National Prison Project, are likely to be more familiar with and attentive to the problems posed by the remedial stage. If counsel are aware of the pitfalls of the remedial dilemma, they can overcome many of the limitations of the broker approach by building provisions that cast the court in the role of a catalyst.

320 Plaintiffs' counsel may cast the court in the catalyst role by building provisions into a negotiated or proposed decree that require the participation in a deliberative process of remedial development and trigger automatically the imposition of sanctions in the event of substantial noncompliance. For example, in Spear v. Ariyoshi, "No. 84-1104 (D. Haw. June 12, 1985), plaintiffs' counsel introduced the concept of a representative panel of experts to oversee the remedial process in consultation with members of the prison system and outside experts. See supra note 242-43. In South Carolina, the consent decree "establishes a panel of mutually agreed upon experts to evaluate staffing and other needs in the critical areas 
through which the key actors in the prison system develop an effective remedy. ${ }^{321}$

The catalyst's strategy permits those seeking change to adopt a more systemic approach to the problems underlying constitutional violations. The process involves the actors responsible for implementing the results of the deliberations. ${ }^{322}$ The catalyst makes use of court-appointed facilitators and experts to provide prison officials with the information and expertise necessary to engage in a deliberative planning process. ${ }^{323}$ This interaction between experts and participants in the prison dynamic exposes prison officials to alternative approaches and facilitates the development of more effective solutions to the problems at issue. Through exposure, participation, and deliberation, the catalyst's strategy reduces the prison system's characteristic resistance to change. ${ }^{324}$

The catalyst's strategy avoids the problems that frustrate the reform efforts of the deferrer, director, and broker. She neither depends entirely upon the prison officials ${ }^{325}$ nor attempts to by-pass them entirely. ${ }^{326}$ Nor does the catalyst rely upon lawyers functioning within the constraints of the adversary process. ${ }^{327}$ The catalyst's commitment to process and the institutionalization of change

of security and medical and mental health care." Kluger, South Carolina Settlement Limits Population, Enforces Standards, 5 NAT'L Prison Project J. 1, 9 (Fall 1985).

321 See supra text accompanying notes 230-32.

322 Although in theory nothing limits the catalyst's capacity to ensure inmates' and guards' involvement in the planning process, they are usually excluded from direct participation. To the extent that direct involvement in the process of norm development facilitates institutionalizing those norms, see supra note 232, the catalysts' failure to include inmates and guards constitutes a limitation on her capacity to resolve the remedial dilemma. Counsel can compensate for this limitation by involving the prisoners and guards in the development of the parties' negotiating positions. However, there are limitations on plaintiff' capacity to perform this role, such as conflicts among members of the class, unwillingness of inmates to compromise for symbolic reasons and resistance of defendants or the court to inmates' inclusion in the negotiations. See Note, supra note 84, at 1076-77 \& $\mathrm{nn}$.7476; cf. Bell, Serving Two Masters: Integration Ideals and Client Interests in School Desegregation Litigation, 85 YALE L.J. 470 (1976) (describing conflicts between class members, and the attorneys' failure to represent all interests adequately).

323 The problems of limited expertise and professional exchange characterizing the organizational dynamics in prisons accentuate the importance of the catalyst's attention to process in prison cases. In cases involving institutions that do not share these problems, this benefit of the catalyst approach may be unnecessary.

324 See, e.g., M.K. Harris \& D. SpILler, supra note 17, at 188 (concluding that the defendant coroner's involvement with the master in developing plans for keeping the mentally ill out of jail appears to have avoided previous compliance problems).

325 The deferrer's strategy; see supra note 190 and accompanying text.

326 The director's approach; see supra note 204 and accompanying text.

327 The broker's strategy; see supra notes 219-21 and accompanying text. 
directly addresses the dynamics of organizational stasis and permits the court to develop and institutionalize a new normative framework.

The catalyst's strategy is nevertheless subject to a variety of potential limitations. The processes set in motion by a catalyst are time consuming. ${ }^{328}$ The resulting delay in implementing the remedy means that inmates are forced to suffer continuing constitutional injuries. ${ }^{329}$ Where the harm to the inmates is visible and extreme and the remedy well-established and uncontroversial, the participatory approach to remedy formulation and the resulting delay is unnecessary and unjustified. Without the catalyst's process, however, meaningful change in prison norms may never occur.

The effectiveness of the catalyst's deliberative process may also be constrained by the limited involvement of key participants in the dynamics of organizational stasis. Line-workers are at best tangentially involved in the remedy formulation process. Many of these actors will be excluded entirely. Furthermore, the impact of the catalyst's strategy is reduced as the court's reliance on lawyers increases. The court can reduce these liabilities by careful attention to the process by which the remedy is formulated. ${ }^{330}$

The boundaries of the constitutional norm pose an additional constraint on the scope of the catalyst's normative agenda. Unless the prison officials choose to embrace more systemic approaches to the underlying problems facing the prison system, the catalyst may not require the parties to consider and adopt approaches that exceed

$328 \mathrm{It}$ is in part for this reason that courts have turned increasingly to masters and other compliance aids to oversee the remedial process. This phenomenon has not gone without criticism. See Brakel, supra note 7, at 164-66; Fiss, Against Settlement, 93 Yale L.J. 1073 (1984). However, if properly supervised and trained, masters can perform an invaluable role in the compliance process and operate within constraints that respect the limits of the judicial function. See generally Sturm, Special Masters Aid in Compliance Efforts, 6 NAT'L Prison Project J. 9, 11-12 (Winter 1985) (noting that the effectiveness of a master often hinges upon her ability and perceived legitimacy).

329 Because of this time lag, inmates may feel alienated by the process, and predisposed to engage in disruptive activities that may detract from the remedial endeavor. Recalcitrant defendants may very well use delay as a tactic to avoid implementation. See Note, supra note 84, at 1074-77. One way to minimize the extent of inmates' harm is to award damages to compensate for the injury caused by ongoing constitutional violations. See infra note 345-47.

330 See, e.g., Rhem v. Malcolm, 507 F.2d 333, 340 (2d Cir. 1974) (representative of corrections department included as part of Office of Compliance Coordinator); Wright, Revived Settlement Halts Trial in Arizona Case, 5 NAT'l Prison Project J. 4, 6 (Fall 1985) (magistrate insisted that the Director of Corrections be present at the bargaining table, so that the settlement meetings became a forum not only for bargaining but for the education of the prison administration). 
the scope of the legal violation. ${ }^{331}$ Under these circumstances, the catalyst may be unable to prevent the parties from adopting shortterm solutions that may ultimately perpetuate the problems underlying unconstitutional prison conditions.

Unlike the other approaches, however, the catalyst has the potential to induce prison officials to tackle prison problems systemically by exposing them to alternative approaches and involving them in the information-gathering and planning process. The catalyst requires prison officials to engage in a deliberative process at least with respect to identified legal violations, perhaps empowering them to use skills obtained there in other areas. Moreover, the catalyst may adopt a systemic view of the causes of constitutional violations that accounts for the underlying organizational dynamics.

Most significantly, the extent of the catalyst's capacity to force the development of new normative standards may be limited by the willingness of prison officials to embrace the process of norm development. The process structured by the catalyst cannot take place without the cooperation of the participants in the prison dynamic. The two-pronged nature of the catalyst approach enables the court to overcome this potential obstacle. By combining the process of norm development with the imposition of sanctions for failure to engage in this process, the catalyst creates incentives for intransigent public officials to participate in the deliberative process or to give way to new participants who support the new normative agenda. ${ }^{332}$ Thus, the catalyst's strategy, although not without limitations, is well suited to foster the developrnent of a new normative framework in the prison.

\section{B. The Court's Capacity to Create Incentives to Undertake Change}

The incentive system in prisons tends to reinforce the status quo and discourage efforts to change routines, policies, and norms. ${ }^{333}$ Courts can create incentives to induce prison participants to take the steps necessary to eliminate unconstitutional conditions. The court's authoritative position and the public nature of judicial proceedings

33 I See, e.g., Bell v. Wolfish, 441 U.S. 520, 539, 554 (1979) ("Courts must be mindful that these inquiries spring from constitutional requirements and that judicial answers to them must reflect that fact, rather than a court's idea of how best to operate a detention facility."); Swann v. Charlotte-Mecklenberg Bd. of Educ., 402 U.S. 1, 15-16 (1971) (indicating that "[o]nce a right and a violation have been shown," the duty of the court is to correct the offending condition).

332 See infra notes $379-92$.

333 See supra notes $82-100$ and accompanying text. 
enable a court to generate changes in the community's perception of the prison and the value of reform. The public nature of judicial proceedings exposes the community to the need for reform in prisons under court order. A remedy containing standards and deadlines creates a mechanism to hold the prison administration publicly accountable for its performance. ${ }^{334}$ Conduct that formerly eluded detection or supervision is subject to public scrutiny and measured against judicially approved goals and standards. ${ }^{335}$ By fostering a more receptive political environment for prison reform, the court's public pronouncements can enhance the capacity of individuals or groups within the prison system to obtain resources for particular programs. ${ }^{336}$ The court may put willing participants in contact with influential authorities ordinarily inaccessible to them. Increased public and professional support for reform changes the typically conservative incentive structure of prison administrators.

Judicial support for attaining expertise and meeting minimum standards may elevate the professional standards of the corrections profession. The court's attention to prison administration enhances the visibility, status, and prestige of the corrections profession. ${ }^{337} \mathrm{~A}$ number of commentators have linked judicial intervention with the increasing professionalization of corrections, at least at the adminis-

334 See, e.g., L. YACKLE, supra note 51 , at 34 (describing increase in staff in anticipation of upcoming hearing).

335 Compliance hearings may stimulate efforts to comply, as do deadlines. See M.K. Harris \& D. SpILler, supra note 17, at 18.

$336 \mathrm{By}$ using the court as a scapegoat, administrators are sometimes able to make improvements that the public otherwise might not tolerate. See id. at 110 . For example, administrators under court order may obtain resources that were previously unavailable, thereby enhancing their power to bring about change. See, e.g., id. at 24$25,111,411-12$ (describing an increase in appropriations for prisons following judicial intervention in each case studied); id. at 209 (describing how a bond issue for the construction of a new jail "failed every time it had been presented to the voters prior to litigation," and passed after the case received public attention); id. at 314-15 (describing how litigation reportedly played an important role in raising funds for the prison in Hamilton v. Schiro, 338 F. Supp. 1016 (E.D. La. 1970)); Champagne, supra note 283, at 96 (recounting how the court in Taylor v. Sterrett, 344 F. Supp. 411 (N.D. Tex. 1972), aff'd in part and rev'd in part, 499 F.2d 367 (5th Cir. 1974), cert. denied, 420 U.S. 983 (1975), forced large expenditures for jail improvements). As a result, guards and counselors may receive additions to their staff and training. See, e.g., M.K. HARRIS \& D. SPILLER, supra note 17, at 24 (documenting increases in staff resulting from litigation).

337 See, e.g., M.K. HARrIS \& D. SPILlER, supra note 17, at 110 (finding that corrections litigation contributed to unified department and the appointment of well qualified individuals); L. YACKLE, supra note 51, at 40-41 (noting that after Newman v. Alabama, 460 U.S. 1083 (1982), the prison was the subject of several major studies concerning the condition of Alabama's penal system). 
trative level. ${ }^{338}$ In response to court intervention, some corrections departments have created the position of implementation officer, which frequently serves as a stepping stone to high level management positions. ${ }^{339}$ Other corrections professionals have become involved as consultants and experts in connection with pending or threatened litigation. These more sophisticated professional standards, techniques, and communications systems may act as an external incentive to conform to the demands of a more professional community.

The court can directly alter the incentive structure by rewarding administrators for compliance. It can merely praise particular individuals or the system as a whole for any progress. It can restore to the prison system some degree of autonomy or discretion. Most significantly, it can reduce or terminate its active involvement with the prison system. ${ }^{340}$ Corrections officials thus have strong incentives to comply with court orders as a means of limiting further intervention.

338 See J. JACOBS, supra note 29 , at 54-55, 57; M. Feeley \& R. Hanson, supra note 252, at 11; cf. L. YACKLE, supra note 51, at 257-58 (describing how the Alabama corrections department in the wake of Pugh and James attracted a new, young, cerebral group of professional administrators).

Guard training is sometimes a component of court orders addressing the problem of violence. See, e.g., Ruiz v. Estelle, 679 F.2d 1115, 1144, 1148-49 (5th Cir. 1982), modified, 688 F.2d 266 (5th Cir.), cert. denied, 460 U.S. 1042 (1983). But cf. Hoptowit v. Ray, 682 F. 2d 1237, 1251 (9th Cir. 1982) ("[T]o require prisons to have adequate recruiting, screening and training programs is an impermissible judicial involvement with the minutiae of prison administration."). Recently, training programs in some systems have begun to take into account the legal requirements and constraints within which guards must operate. Some training programs now include components focused on legal standards and a number of states now require a high school diploma as a prerequisite for employment as a guard, a trend which has been noted by the courts. See Aguilera v. Cook County Merit Board, 760 F.2d 844, 848 (7th Cir.), cert. denied, 474 U.S. 907 (1985); NAT't. INST. OF LAW ENFORCEMENT \& Criminal Justice, The National Manpower Survey of the Criminal Justice SystEM 1, 85 (1978) (77\% of the responding institutions required high school diplomas for employment as custodial officer).

339 See, e.g., Black v. Ricketts, Civ-III PHX CAM, Court Monitor's Third Progress Report (D. Ariz.) at 5 (touting top level administrator designated by Director "as responsible for the coordination and direction of all compliance efforts"); Memorandum from Perry Johnson, Director, to Deputies and Wardens (February 1, 1984) (on file with the University of Pennsylvania Law Review) (announcing the formation of a planning and oversight committee and the appointment of a project director responsible for overall monitoring of all activities pursuant to the Decree).

340 See, e.g., M.K. HARrIS \& D. SPILLER, supra note 17, at 17, 401-03 (noting that the court in Collins v. Schoonfield, 344 F. Supp. 257 (D. Md. 1972), used relinquishing jurisdiction as an incentive for compliance, and that the defendants actively pursued compliance in an effort to persuade the court to relinquish jurisdiction). 
Their superiors are given an incentive to replace incompetent leadership with individuals capable of satisfying judicial standards. ${ }^{341}$

Courts can impose substantial costs on those who cannot or will not comply with the court's order. One important sanction is the exposure of failure, incompetence, or scandal. ${ }^{342}$ Officials whose conduct is otherwise invisible to the public must face public criticism, humiliation, and potential discharge if they fail to respond effectively to court mandates. ${ }^{343}$ The exposure of brutal and inhumane conditions coupled with judicial condemnation of public officials for their intransigence or incompetence can create external political pressure for change. ${ }^{344}$

A court has the power to impose direct costs for failure to comply. It can increase its degree of supervision and reduce the discretion and autonomy of prison officials in the face of continued refusal to develop a plan to achieve compliance. Courts can force the prisons to internalize the cost of continued constitutional violations by requiring the corrections department to compensate inmates for the

341 "In Holt, Hamilton, and Collins, a change in personnel involving the highest level correctional official was believed to have aided the compliance process." M.K. HARRIS \& D. SPILLER, supra note 17, at 15. The new personnel appointed in Collins "had no obligation to defend the status quo," supported the court orders, and were described as "capable" and possessing a "marked change in attitude." Id. at 38485.

342 Litigation can contribute to the exposure of new information revealing shocking conditions and practices that do not comport with public expectations. See, e.g., id. at 9, 410 (noting that Collins "generated considerable publicity . . . . Commissions were established ...., special studies were undertaken, [and] media attention increased" such that the Baltimore city jail, which had operated in relative isolation, was subjected to considerable public attention).

343 The prison administration in command in Rhode Island when the litigation in Palmigiano v. Garrahy, 443 F. Supp. 956 (D.R.I. 1977), began was "strictly political" and had no experience with, or expertise in, corrections. See The Organizational Consequences of Remedial Law, supra note 46, at 17. The pressure and visibility created by the law suit led to their dismissal and replacement with more qualified leadership.

344 See, e.g., M.K. HaRris \& D. SPILlER, supra note 17, at 9, 84-85, 182-84, $382-$ 83 (discussing how the participants in Holt $v$. Sarver, Holland $v$. Donelon and Collins $v$. Schoonfield believed that the media's exposure of facts about the respective prisons during the course of the litigation greatly contributed to the creation of a political climate conducive to prison reform and influenced the legislature to adopt a more progressive attitude toward prison reform). In the wake of litigation, public opinion appears to have shifted sufficiently for the legislature to feel an impact. See id. at 10 11. Public exposure contributed to a political climate conducive to change. See id. at 86; L. YACKL.E, supra note 51, at 66 . Officials who desire reform sometimes use media coverage to obtain support for the court order. In Alabama, the Commissioner invited the press into the prison after the court issued an extensive remedial order in an effort to pressure the legislature into increasing prison appropriations. See id at 64-65. 
continuing deprivation of their constitutional rights. This can be done by finding the defendants in contempt for failing to comply with the court order, assessing the damage caused inmates as a result of continuing noncompliance, and awarding these damages to inmates as compensation for the harm caused by the defendants' contempt. ${ }^{345}$ Individuals who are responsible for constitutional deprivations may be held accountable through damages awards. ${ }^{346}$

A court may also impose coercive civil contempt sanctions to induce compliance. ${ }^{347}$ Coercive contempt fines run against the department, and can be used to fund programs to achieve compliance. ${ }^{348}$ Finally, courts may order the defendant's to release inmates or even close the institution in response to the defendant's intransigence. ${ }^{349}$

345 See, e.g., L. YACKLE, supra note 51, at 171-72 (describing Judge Pointer's use of contempt to levy fines for noncompliance and require part of the fine to be paid directly to inmates in Thomas v. Gloor, No. 77-P-66-S (N.D. Ala. Apr. 16, 1980)).

346 See Goodson v. City of Attanta, 763 F.2d 1381 (11th Cir. 1985) (court awarded inmates $\$ 45,000$ in compensatory damages from city and director of jail and $\$ 5000$ in punitive damages for denial of medical care and infliction of unconstitutional conditions); Williams v. Lane, 646 F. Supp. 1379, 1409-10 (N.D. Ill. 1986) (inmates entitled to award as compensation for pain, suffering, mental anguish, and lost wages caused by prison authorities' unconstitutional conduct). But see $\mathbf{P}$. Schuck, Suing Government: Crtizen Remedies for Official Wrongs 59-81 (1983) (arguing that imposing personal liability creates perverse incentives to engage in self-protection and risk minimization).

347 See, e.g, Officials Sentenced in jail Case, N.Y. Times, March 17, 1987, at A16, col. 5 (reporting that "Santa Clara County Supervisors . . . were sentenced to jail terms ... for violating a judge's order to provide more jail cells to ease overcrowding"); Miller v. Carson, 550 F. Supp. 543, 548-49 (D. Fla. 1982) (court held defendants in civil contempt and imposed a fine of $\$ 5000$ per day for violations of maximum capacity provisions of permanent injunction).

348 See, e.g., Campbell v. MacGruder, Memorandum Opinion (September 30, 1983), cited in, Marsh v. Barry, 705 F. Supp. 12, 13 n.1 (D.D.C. 1988) (holding the mayor of Washington D.C. and top correctional personnel in contempt for violating an overcrowding order and fined them $\$ 50,000$ plus $\$ 1000$ per day for each day noncompliance continued); Powell v. Ward, 487 F. Supp. 917 (S.D.N.Y. 1980) (holding prison officials in contempt and requiring payment of fine into inmate fund to be used to implement decree), modified, 643 F.2d 924 (2d Cir.), cert. denied, 454 U.S. 832 (1981). In Puerto Rico, the defendants have been in contempt for over a year and substantial fines have accumulated and are being used to fund compliance efforts. See Telephone interview with Vincent Nathan, supra note 205.

349 See, e.g., Ramos v. Lamm, 520 F. Supp. 1059, 1062 (D. Colo. 1981) (ordering that "Old Max" [Canon Correctional Facility Max] be closed); Benjamin v. Malcolm, 564 F. Supp. 668, 691 (S.D.N.Y. 1983) (denying motion to modify orders limiting population of city jail); L. YACKLE, supra note 51, at 95 (noting that Judges Johnson and Hand "enjoin[ed] state authorities from 'accepting or permitting the acceptance' of new prisoners into the system urtil the population of the four major institutions was reduced to ... 'designed capacity'.); id. at 171-72 (describing Judge Varner's order in Bibb v. Montgomery County, 76-380-N (M.D. Ala. 1976), that required 
In sum, the court has at its disposal a range of rewards and sanctions that can influence the incentive structure within the prison system. In the following sections the four managerial strategies are analyzed to determine the ability of each to use these judicial tools to change the prison's incentive structure.

\section{The Deferrer and the Limits of Normative Authority}

The deferrer relies primarily, if not exclusively, on the symbolic and persuasive authority of judicial pronouncements to create the impetus for change within the prison. ${ }^{350}$ This passive approach to promoting compliance has little or no effect on the preexisting incentive structure. The perception among the prison system's key actors that the court intervention is illegitimate, ill-advised, and counterproductive reduces the symbolic power of the court's pronouncements. ${ }^{351}$ In the absence of direct incentives to take the court seriously, prison officials have powerful incentives to minimize judicial impact.

Prison administrators face considerable pressure from both above and below to maintain the status quo. Unless prison officials view the court as a higher moral and legal authority, they treat the court as one of many constituents to which they must respond. The prison administration faces considerable pressures to minimize its efforts to undertake the reforms necessary to comply with the court's orders. ${ }^{352}$ If officials believe that no negative consequences will flow from noncompliance, there is little to counteract their reluctance to risk the disruption and resistance that may accompany change. Once the prison administration discovers the court's reluctance either to impose sanctions or to assume an active role in overseeing compli-

Montgomery County officials to release a number of inmates whom the Judge, on the Sheriff's advice, decided were not dangerous).

350 See supra text accompanying notes 190-203. To the extent that the deferrer establishes deadlines for compliance and holds hearings, she adds a dimension of accountability and public scrutiny that may induce officials to act. This is particularly true if the hearings receive media attention.

351 See, e.g., M.K. HARRIS \& D. SPILlER, supra note 17, at 360 (stating that the warden "feared that by upholding [the] petitions of prisoners the courts were "building up an army of revolutionaries inside our jails" "). The judge's general reputation and stature may, at least initially, affect the parties' perception of the seriousness and legitimacy of the court's orders. See, e.g., id. at 93, 94 (concluding that the district court judge earned respect of defendants by his stern demeanor and his reputation as a "tough" judge; consequently, defendants followed letter of court orders); T. Storey, supra note 110, at 22 ("From the moment Lasker was drawn as the judge for our trial, the City was very anxious to talk to us real quick.").

352 See supra text accompanying notes 109-20. 
ance, it has little incentive to take court intervention seriously. ${ }^{353}$ Unless the prison administration is predisposed to pursue reform, it is likely to pursue a strategy that minimizes the effects of the court's intrusion and encourages the court to accept the defendants' control over the agenda.

The deferrer fails to create incentives even for the reformer who shares the court's normative perspective. Because the court delegates to the current administration responsibility for effecting change, the reformer cannot use the court as a scapegoat to justify unpopular programs. ${ }^{354}$ The reformer risks antagonizing both internal and external constituencies by publicly conceding that reform is necessary and that court intervention is legitimate. ${ }^{355}$

The deferrer's reliance on the prison administration for compliance leaves intact the prison's preexisting incentive structure supporting the status quo. Guards are not generally directly accountable to the court and face little danger of sanction for ignoring or defying the deferrer's pronouncements. They are unlikely to be rewarded for facilitating the court's orders and may in fact be penalized by their peers for supporting the court. ${ }^{356}$ They have no investment in remedial provisions that were developed and imposed by administrators or their lawyers. Resentment of outside interference combined with the internal pressures to resist administrative reform will usually motivate guards to oppose judicially inspired change.

The deferrer approach tends to discourage inmates from embracing court intervention to accomplish reform. When inmates realize that the court has delegated the responsibility for instituting reform to the prison officials, they are likely to reduce their reliance on litigation to challenge prison conditions. ${ }^{357}$ If inmates are essentially excluded from the remedy formulation and implementation

353 Perceived judicial reluctance to use sanctions diminishes the responsiveness of defendants to court orders. See, e.g., M.K. Harris \& D. SpILler, supra note 17, at 15 ("The judge's reluctance to enforce compliance reinforced the defendants' unwillingness to comply with provisions with which they disagreed or which presented difficulties from a management standpoint."); id. at 308 (concluding that the defendants' knowledge of the judge's reluctance to impose sanctions diminished the court's capacity to impose effective enforcement mechanisms).

354 See, e.g., id. at 97 (recalling that a Commissioner noted that general court orders provided little political protection).

355 See, e.g., id. at 16, 95 (noting that in Holt $v$. Sarver, the administrator's receptivity to the litigation antagonized the legislature, which was openly hostile to court intervention).

356 See supra note 93 and accornpanying text.

357 See Note, supra note 84 , at 1077 n. 80 . 
process and observe no concrete changes flowing from judicial intervention, they have little incentive to cooperate with court-ordered change. Prisoners may then pursue reform through disruption and violence.

The deferrer also is unlikely to create indirect incentives by mobilizing public opinion. The court's informal suggestions and general pleas for compliance are unlikely to trigger the public response that creates an environment receptive to change. ${ }^{358}$ The deferrer introduces few incentives for prison officials to undertake the changes necessary to eliminate unconstitutional prison conditions.

\section{The Director and the Limits of Assuming Control}

The director attempts to achieve compliance by assuming direct control over aspects of remedial formulation and prison management. ${ }^{359}$ However, the court cannot unilaterally implement administrative reform, and it lacks the capacity to use administrative control to alter organizational behavior structures. The court functions outside the prison system's hierarchy and has little direct contact with or control over many of those whose cooperation is necessary to achieve compliance. The court's power to hire and fire, or otherwise to exercise direct administrative control, lies at the margins of the boundaries of the court's legitimate authority and is subject to legal challenge. The director's range of activity is defined by the scope of the legal violation, further limiting its potential to influence the conduct of prison officials. ${ }^{360}$

The director's assumption of control challenges the strong commitment to autonomy that pervades the prison system. ${ }^{361}$ By attempting to assume control, the court creates incentives to chal-

358 If the prison administration is supportive of the court mandate and has the political support of its superiors, these parties may be able to generate sufficient political support for prison reform to pressure an affirmative legislative response, even under the deferrer approach. See, e.g., M.K. HarRis \& D. SPILLER, supra note 17, at 95-96 (noting that when the prison administration changed, the legislature appropriated additional funds to facilitate compliance); id. at 166-67 (concluding "that the Holland suit provided an impetus and helped persuade the parish council to approve the necessary funds" for a medical program that "went far beyond what was required by the court orders").

359 See supra text accompanying notes 204-18.

360 See supra notes $301-08$ and accompanying text.

361 See supra notes $28-81$ and accompanying text (explaining roots of institutional preoccupation with autonomy). Prison administrators are likely to be threatened by the court's assumption of authority over prison matters. See, e.g., L. YACKLE, supra note 51, at 114 (noting that Commissioner Locke was threatened by 
lenge the its authority and resist its intervention. Prison officials exploit the court's desire to achieve compliance by creating the appearance of compliance without actually changing prison practices. $^{362}$ Alternatively, these officials may respond to judicial oversight by formalizing their contact with the court, hardening their commitment to their positions, and challenging the court's activities on appeal. ${ }^{363}$ This response delays the implementation process, is likely to halt the momentum of the reform effort, and may lead the court to reduce its involvement and defer to those in the prison.

By assuming direct responsibility for compliance, the director also enables prison officials to disclaim responsibility for initiating reform and to minimize their involvement in the reforms undertaken by the court. ${ }^{364}$ The judge's political independence enables her to initiate reforms that would be politically risky for insiders to initiate directly. However, risk-averse officials have incentives to distance themselves publicly from reform initiatives and may refuse to take the steps necessary to ensure success. Those hostile to court intervention may abdicate responsibility for developing new techniques and approaches to maintain order within judicially-defined boundaries, and may even attempt: to undermine the court's compliance efforts. Any resulting disruption can be blamed on the court and used to prove the illegitimacy of the court's role. The predictable public controversy is likely to divert attention from the underlying prison conditions and undercut the public pressure to undertake change.

The director also fails to motivate non-parties, such as the legislature and the parole board, to assume responsibility for their role in perpetuating the prison problems. The director's assumption of control challenges the authority of the state and thus creates incen-

the court-appointed experts summoned to Alabama because of the determination that he could not handle his job).

362 See, e.g., M.K. HARRIS \& D. SpILLER, supra note 17, at 261 (recounting that a penologist hired in response to court order "reported that his hiring was a shallow gesture intended only to placate the court"); supra note 292 (describing prison officials' attempts to disguise the true prison population).

363 See Note, supra note 84, at 1076 n.73 (documenting efforts of prison officials to formalize contact with court and to deal only through counsel).

364 See, e.g., L. YACKLE, supra note 51, at 109 (noting how state political figures attempted to disclaim responsibility for prison conditions by "fastening blame entirely on the commissioner and the board" in the aftermath of Newman v. Alabama, 349 F. Supp. 278 (M.D. Ala. 1972), cert. denied, 421 U.S. 948 (1975), and James v. Wallace, 382 F. Supp. 1177 (M.D. Ala. 1974)). 
tives for outsiders to resist cooperation. ${ }^{365}$ The director imposes no additional costs on these agencies for their noncooperation. ${ }^{366}$

In fact, by visibly adopting the director approach, the court profoundly limits the range of effective incentives available to it. The director cannot fault intractable parties for noncompliance because the court, rather than the defendants, has assumed ultimate responsibility for implementation. Furthermore, once she has assumed direct control, the director can no longer threaten prison administrators with the prospect of reduced discretion and autonomy. The parties are likely to perceive the director's discomfort with her role and her unwillingness to assume greater control. Because the director also exhibits reluctance to use the court's formal sanctioning power as an incentive, ${ }^{367}$ it has no further methods to induce change in the behavior of the parties. ${ }^{368}$

Prison officials are likely to capitalize on the director's vulnerability by increasing their resistance to the court's orders. ${ }^{369}$ The court's success, rather than the defendants, is at risk. By resisting and challenging the court's authority, the officials may force the court to assume a more deferential stance, either by exhausting the court or winning a reversal on appeal. ${ }^{370}$ Defendants always have

365 See, e.g., M.K. HaRris \& D. SpILLER, supra note 17, at 180, 181 (noting that " "buck passing"" [among a variety of responsible agencies] was a common problem").

366 See, e.g., L. YACKLE, supra note 51, at 113 (discussing the parole board's indifference to Judge Johnson's entreaties to change its parole policies; the board was not reprimanded for its resistance, and was not forced to comply with the judge's requests). In fact, some outsiders use their resistance to the court for political purposes and generate attention and support by standing up to the federal court. See infra note 449 and accompanying text.

367 See supra note 218 and accompanying text.

368 See, e.g., L. YACKLE, supra note 51, at 21 (explaining how Judge Johnson's unwillingness to use contempt affected the defendants' perception of the need to comply: "Judge] Johnson's preference for giving state authorities ample time to change their ways and only threatening to exercise his contempt power was put forward as evidence that his orders were questionable in the first instance"); of. $\mathrm{T}$. Schelling, The Strategy of Conflict 6 (1960) (arguing that the credibility of a threat is related to the threatener's commitment to enforce the threat).

369 In Alabama, plaintiffs asked Judge Varner to order the State Comptroller and State Treasurer to be added as parties and ordered to spend particular funds on prisons. The judge postponed action on the motion, "hoping that the threat of new orders . . . would pressure the Legislature into authorizing funds on its own." Instead, the Legislature reduced the budget for the prisons by seven million dollars. "The evidence is that the Alabama legislature . . . called Judge Varner's bluffanticipating that the older, more conservative man would balk at forcing state expenditures directly." L. YACKLE, supra note 51, at 195-96.

370 See L. YACKLE, supra note 51, at 226 ("Knowing that Varner could not order the release of more prisoners, and guessing that the judge would not impose heavy 
the option of complying in the future if the threat of further action appears imminent. Thus, the director is limited in her capacity to alter the conduct or incentives of those whose cooperation is essential to reform.

\section{The Broker and the Limits of Praise and Threats}

The broker uses the court's informal bargaining power to cajole the defendants, through praise and threats, into taking the steps necessary to create incentives to induce compliance. ${ }^{371}$ The broker's informal approach may be effective in stimulating some compliance, particularly if the parties believe that the court's threats of future sanctions are serious. ${ }^{372}$ Moreover, an agreement between the parties that requires the defendants to increase resources and involve experts as a part of its reform process may provide incentives for prison participants to comply with the court's order. Nevertheless, the broker's bargaining approach suffers from many of the same defects that constrain the cleferrer's capacity to alter the prison's existing internal incentive structure. ${ }^{373}$

The informality and invisibility of the broker's methods tend to limit public exposure and the potential pressure that flows from it. More importantly, the broker's informal pressures do not affect many of the key actors within the prison system, and are likely to be neutralized by the system's powerful disincentives to change. Prison officials will balance the immediate risk of disruption and loss of autonomy against the uncertain threat of future sanctions. The threats are an effective incentive only if taken seriously by the prison

fines or put important state officers in jail, [the governor] now wished to proclaim victory and to withdraw ...." (emphasis omitted)).

371 See supra notes $219-29$ and accompanying text.

372 In Holland, participants reported that "the judge's act of calling . . . defendants into his chambers was effective in making things happen" because it made defendants feel they were "personally responsible and that compliance was a serious matter." This perception was subsequently buttressed by the court's moderate escalation of sanctions in the form of attorney's fees. See M.K. Harris \& D. SPILLER, supra note 17 , at 198-99.

373 The lawyers, particularly plaintiffs' counsel, can compensate for these limitations by including in the agreement terms that automatically create incentives for compliance. For example, in Alabama, plaintiffs' counsel built into their agreement compliance deadlines which would trigger hearings. See L. YACKLE, supra note 51, at 193-94. The parties can also agree to the automatic imposition of sanctions, release, or fines in the event of noncompliance. See Harris v. Pernsely, 654 F. Supp. 1042, 1047 (E.D. Pa.) (discussing a consent order that included a moratorium on prison admissions if population cap was exceeded), cert. denied, 483 U.S. 1041 (1987). 
administration..$^{374}$ The broker loses her power to influence conduct if she fails repeatedly to follow through on her threats to sanction noncompliance. ${ }^{375}$

\section{The Catalyst: Combining Internal Process With External Pressure .}

The catalyst's management strategy is designed to use both positive and negative incentives to induce the members of the prison system to implement change. The catalyst's synthesis of traditional judicial sanctions and a deliberative remedial process enables the court to create sufficient pressure to induce prison officials to undertake compliance and yet defuse the resistance that sometimes follows coercive intervention.

The catalyst structures a process of remedial formulation and enforcement that focuses attention on the prison problem. This strategy can increase public support for and interest in prison reform and elevate the stature of corrections professionals. By strengthening the political leverage of the prison system's key actors and creating structures for joint planning, the catalyst enables prison officials to interact with politically powerful figures normally inaccessible to them. ${ }^{376}$ Administrators may have increased access to governors, legislators, state judges, and national experts in corrections. ${ }^{377}$ Line workers and inmates may have access to court-appointed officials and to superiors seeking information about the status of prison conditions and input into planning. If prison officials lack the skills and expertise necessary to make effective use of the process structured by

374 See T. Schelling, supra note 368 , at 11.

375 See, e.g., M.K. HARRIS \& D. SPILLER, supra note 17, at 287-88 (the "court's tolerance of noncompliance over an extended period fostered skepticism" over whether the court would enforce its orders; defendants perceived that court would not impose contempt sanction, so that defendants were "largely left free to ignore specific provisions with which they disagreed or which they considered impractical"); L. YACKLE, supra note 51, at 233 (discussing Judge Varner's threat to use contempt if state officials did not release inmates on their own; his "tough talk failed to produce results" because no one "believed that Judge Varner would actually take severe measures").

376 See, e.g., M.K. HARRIs \& D. SPILler, supra note 17, at 193-94 (discussing how the master set up conferences with prison administrators, parish officials, state judges, the coroner, and other officials whose assistance was needed to achieve compliance).

377 See, e.g., M.K. Harris \& D. SPILler, supra note 17, at 205-08 (noting that the master in Holland v. Donelon, No. 71-1442 (E.D. La. May 16, 1972), made parish officials sensitive to ways their activities could affect population level, and enabled jail officials to influence action of state judges, the sheriff, jail staff members and parish council by establishing a process of consultation and planning with jail administrators and other parish officials and keeping a general spotlight on the jail). 
the catalyst, court appointment of intermediaries and experts creates opportunities for information exchange and coordination. ${ }^{378}$ Unlike the director, the catalyst vests the prison officials with full managerial responsibility for compliance. The benefits of increased expertise and resources flow directly to the prison community. This enhanced responsibility and capacity provides the incentive and the opportunity to attract more qualified individuals into the profession. ${ }^{379}$

The catalyst uses its formal powers to convince the responsible public officials that the only way out of judicial intervention is compliance. The court structures a system of accountability that provides ongoing incentives for change. Regular information gathering and reporting obligations, along with deadlines for particular compliance activities, pressure the defendants to achieve compliance. ${ }^{380}$

378 See First Report of Special Master in Harris v. Pernsley, No. 82-1847 at 6 (E.D. Pa. Nov. 19, 1987) (recommending that Philadelphia prison system submit a proposal to the Pennsylvania Commission on Crime and Delinquency for the establishment of Population Control Unit within prisons); Draft Memorandum from Prisons Superintendent (Aug. 25, 1988) (documenting that Philadelphia prisons received grant from PCCD to establish Population Management Unit and appointed manager to facilitate flow of information between agencies). A number of individuals have developed expertise as compliance officers, and they have begun to communicate regularly about common professional concerns. A manual for special masters in prison litigation was prepared by the National Institute of Corrections. The role of court-appointed compliance officials includes tapping available expertise in the corrections field to aid defendants in their compliance efforts. See National Institute of Corrections, U.S. Department of Justice, Handbook for Special Masters 12-13 (1983). In Puerto Rico, the master undertook to bring in experts from outside the state to aid the defendant in revamping its system. See Telephone interview with Vincent Nathan, Special Master in prison cases in Ohio, Texas, Georgia, New Mexico and Puerto Rico (Dec. 26, 1988) (on file with the University of Pennsylvania Law Review).

Plaintiffs' counsel may also bring to the litigation substantial information concerning the availability of expertise and outside resources. For example, the National Prison Project has developed substantial expertise in remedial options that may provide assistance at the remedial stage. See, e.g., Letter from Alvin J. Bronstein to Judge Pettine (Dec. 9, 1988) (responding to court's request that plaintiffs' counsel provide court and defendants with list of options and programs that have proven effective in other jurisdictions for reducing overcrowding in prisons and jails) (on file with the University of Pennsyluania Law Review).

379 See, e.g., M.K. HARRIS \& D. SPILLER, supra note 17, at 207-08 (asserting that by focusing attention on jail, public officials' responsibility for it, and the court's insistence on compliance, the court facilitated retention of new top level and administrative staff and increased involvement of parish council and others in jail); supra note $34 \mathrm{I}$.

380 See, e.g., M.K. HARRIS \& D. SpILlER, supra note 17, at 194 (noting that the jail manager reported that the master's presence during compliance inspections served as stimulus for improvements); $i d$. at $\mathbf{3 0 5}$ (discussing the defendants' expressed view that compliance reports served as reminder that court was concerned about compliance progress). 
Deadlines taken seriously by the court force prison officials to engage in goal-oriented behavior and to measure their conduct in relation to performance goals. ${ }^{381}$ Regular compliance review generates the public exposure and education crucial to creating a political environment in which reform can occur. ${ }^{382}$

The catalyst uses negative sanctions to pressure prison officials into developing an effective remedy and a process for its institutionalization. By imposing sanctions with political and financial impact on key participants in the prison dynamic, the catalyst personalizes responsibility for compliance and alters the political balance that maintains the status quo. ${ }^{383}$ Coercive and compensatory contempt (damages awarded to inmates to compensate for injuries caused by ongoing noncompliance with the court's decree) internalizes the costs of noncompliance by imposing a continuing tax on the maintenance of unconstitutional prison conditions. ${ }^{384}$ This expenditure forces public officials not directly accountable to the court to take the social and personal costs of noncompliance into account in allocating resources and establishing policy.

The public and political pressure generated by the catalyst's imposition of sanctions can provide prison administrators with the incentives and support necessary to withstand internal resistance to change. ${ }^{385}$ The prison administrator is likely to confront substantial political pressure to take the steps necessary to avoid continued state

381 See, e.g., id. at 205 (arguing that the spotlight on jail sensitized officials to their activities' effects on population level); id. at 400 (in Collins v. Schoonfield, compliance deadlines appeared to have influenced rate of compliance). If deadlines are to serve this function, defendants must perceive that failure to meet them will result in sanction by the court. This does not mean that deadlines cannot be modified if circumstances justify an extension. The importance of enforcement also underscores the importance of setting reasonable time frames at the outset.

382 Other judicial approaches may have the same effect if the court holds regular compliance reviews or hearings.

383 See, e.g., M.K. Harris \& D. SPILler, supra note 17, at 200 (concluding that the participants in Holland v. Donelon, No. 71-1442 (E.D. La. May 16, 1972), viewed contempt motions and award of attorneys' fees as a way of forcing defendants to take court orders seriously, to establish priorities, and end the " 'buck passing' "). If the defendants perceive contempt to be a likely consequence of noncompliance, the filing of a contempt motion may be sufficient to prompt some action toward change. See, e.g., id. at 165, 169-70 (noting that in Holland, council moved toward compliance only after plaintiffs filed contempt motion).

384 The imposition of fines and damages awards alters the prison dynamic, which ordinarily promotes action by imposing costs of public exposure and political risks on those who seek reform. Once continuing fines and damages awards are entered, the only way to eliminate ongoing visibility and public disapproval is by achieving compliance.

385 See supra notes $342-44$ and accompanying text. 
payment to inmates. ${ }^{386}$ Faced with mounting fines, compensatory contempt awards, and public exposure, the prison administrator cannot avoid criticism by acquiescing in the status quo. The potential for continuing political and financial consequences creates further incentives for administrators to educate line workers concerning the legal norms and to take steps to hold them accountable for violations. The possibility of personal damages awards against the line workers provides a direct deterrent to unconstitutional conduct. ${ }^{387}$ If prison officials demonstrate continued inability or unwillingness to manage the compliance process, the resulting public exposure of incompetence and cost of judicial sanctions may pressure political authorities to remove inadequate administrators and staff and bring in competent officials who can participate effectively in the remedial process. ${ }^{388}$

If the unconstitutional conditions persist, the catalyst may implement more drastic measures to limit ongoing harm and create additional incentives for compliance. The court may order prison administrators to release inmates ${ }^{389}$ or close a prison. ${ }^{390}$ Releasing

386 See supra note 384 .

387 This increased accountability may demoralize the line staff, motivating them to passively resist or avoid taking any affirmative steps that would expose them to scrutiny. See P. Schuck, supra note 346, at 71-77. There are some indications that this response may be only a temporary reaction to the initial stages of active judicial involvement. See, e.g., B. Crouch \& J. MarquarT, supra note 29, at 230-31 (discussing how the security staff learned to use those sanctions legally available to them for inmate control, enabling the staff to regain some degree of autonomy and develop a new prison order). This potential response may be minimized by the catalyst's strategy of increasing participation in and understanding of the changes in policy. See, e.g., B. Chilton, supra note 90, at 78 (noting the appointment of monitoring teams based on selections by inmates, prison officials and the court). The guards' union provides a ready vehicle for such inclusion in the deliberative and implementation process. Guard union involvement may defuse some of the opposition to change that characterizes the prison dynamic. See supra note 147.

388 See supra note $250,338,34$ I \& 343 (describing change in personnel resulting from court intervention).

389 Court-imposed population limits actually may be welcomed by the prison bureaucracy. Such limits substantially ease the burdens of day to day life and create pressures outside the system to allocate more resources to the prison system without requiring substantial change in the day to day routine. In Alabama, one of the state's defense witnesses conceded at trial that "the system was so desperately crowded that most staff would welcome a judicial order forbidding the acceptance of more prisoners." L. YACKLE, supra note 51 , at 90.

390 See, e.g., United States v. Michigan, 680 F. Supp. 928, 1047 (W.D. Mich. 1987) (prohibiting admission of new inmates to prison for five days); Grubbs v. Norris, Nos. 80-3404, 80-3518, 80-3616, 80-3617 (M.D. Tenn. October 25, 1985) (precluding the admissions of inmates into reception centers); Champagne, supra note 283, at 91 (describing how in Taylor v. Sterrett, 344 F. Supp. 411 (N.D. Tex. 1972), aff'd in part and rev'd in part, 499 F.2d 367 (5th Cir. 1974), cert. denied, 420 U.S. 
inmates, in particular, may create additional public pressure on elected officials to take the steps necessary to avoid such unpopular actions in the future. ${ }^{391}$ Court-ordered releases may also enable prison officials to reduce the prison population without incurring the substantial political heat that is often generated by early releases. ${ }^{392}$

These more extreme measures may lead to unintended and potentially negative consequences. The defendants may decide to transfer inmates to equally inadequate prisons, ${ }^{393}$ to double- or triple-cell prisoners, ${ }^{394}$ or to build new prisons rather than confront the systemic problems causing prison overcrowding. ${ }^{395}$ The state may attempt to avoid responsibility completely by privatizing some or all aspects of the prison. ${ }^{396}$ The strategy of releasing inmates in response to noncompliance may transform the catalyst unwittingly

983 (1975), the judge ordered the jail closed to further admissions unless jail site selected).

391 See, e.g., L. YACKLE, supra note 51, at 175 (noting that prison authorities were said to " "hope' that a release order from [the court] would 'wake the people and the legislature up' so that money would be allocated for the prisons").

392 See, e.g., id. at 176 (noting that the Commissioner of Corrections was prepared to release short term inmates in waves on the condition that the judge order him to take this action); id. at 212 (asserting that the judge himself chose prisoners to be released in order to spare the governor and commissioner the political costs of making decisions of this kind).

393 See, e.g., id. at 97, 122 (noting that "[j]ail prisoners and county sheriffs were the first to feel the impact of the cap on the prison system's population" because the decrease in prison overcrowding came at the price of ever-increasing crowding in local jails, where conditions continued to deteriorate). These jails were subsequently subject to litigation resulting in the imposition of population caps. See id. at 171-72. The Commissioner of Corrections in Alabama responded to each new order by moving prisoners from the jail concerned to some other jail that was not yet subject to a similar court order. See id. at 171; see also M.K. Harris \& D. SPILlER, supra note 17, at 209-10 (noting that the population cap led to transfer of inmates to inadequate facilities).

394 See, e.g., L. YACKLE, supra note 51, at 206 (noting that "the legislature's reaction to the release of prisoners ... . was to approve plans to "expand' [two new] prisons by assigning two prisoners to cells originally designed for one").

395 See, e.g., id. at 98 (noting that one prison official "meant to deal with crowding in state prisons not by reducing the population in existing institutions, but by building new facilities"); Telephone interview with Vincent Nathan, supra note 205 (noting similar responses in other prison officials). Although building new prisons may temporarily alleviate some overcrowding, it is widely perceived that prison officials cannot build their way out of the overcrowding problem and that the attempt to do so diverts attention and money from more long-range solutions that hold more promise. See B. Cory \& S. Gettinger, Time to Build? The Realities of Prison Construction 5 (1984); Hall, Systemic Strategies to Alleviate Jail Overcrowding 4-5 (National Institute of Justice 1987).

396 See, e.g., Cody \& Bennett, The Privatization of Correctional Institutions: The Tennessee Experience, 40 VAND. L. REv. 829 (1987) (documenting Tennessee's attempt to privatize its entire corrections system). 
into a director if the criminal justice system treats such releases as a solution to the overcrowding problem and eschews attempts to develop more systemic, long-term strategies for addressing this issue. ${ }^{397}$

There also are doctrinal and institutional constraints on the availability and effectiveness of negative sanctions. The prison administration may attempt to excuse noncompliance by showing impossibility or good faith. ${ }^{398}$ Defendants may also seek to avoid contempt by bringing the prison into compliance with the court order in time for the contempt hearing, only to allow the offending conditions to recur after the contempt motion is denied. ${ }^{399}$ Compensatory contempt as a remedy for noncompliance may be problematic due to the difficulty of establishing the value of intangibles such as pain and suffering and dignitary harm. ${ }^{400}$ In addition, some courts believe that incarceration inherently involves some amount of

397 See, e.g., L. YACKLE, supra note 51, at 196 (noting that prison officials "actually seemed to welcome the prospect of a release order" to ease the overcrowding problem). The Fifth Circuit appears to have recognized and approved of this result, ordering the consolidation of a series of jail cases so that a single federal district judge could "assist the state legislature" in managing overcrowding. See Hamilton v. Morial, 644 F.2d 351, 354 (5th Cir. 1981).

398 See Tate v. Frey, 673 F. Supp. 880, 883 (W.D. Ky. 1987) (declining to hold wardens in contempt for violating population cap because they lack control over decision to admit inmates to jail). Good faith is not usually a defense to civil contempt but tends to influence a reluctant court's willingness to find contempt. See, e.g., Newman v. Graddick, 740 F.2d 1513, 1524 (11th Cir. 1984) ("Intent and good faith, while relevant to the amount of punishment, are not defenses to the charge."). But see e.g., United States v. Darwin Constr. Co., 873 F.2d 750, 754 (4th Cir. 1989) (noting that good faith can be a defense to civil contempt in the Fourth Circuit).

399 See, e.g., M.K. HARris \& D. SpILLER, supra note 17, at 169-70 (noting that the defendant did not respond in any way to due process requirements until the plaintiffs initiated contempt proceedings nine months after the court order was entered).

400 In Carey v. Piphus, 435 U.S. 247, 266 (1978), the Supreme Court held that, in the absence of proof of consequential injury, only nominal damages could be awarded for the denial of procedural due process. The Court concluded that "although mental and emotional distress caused by the denial of procedural due process itself is compensable under $\S 1983$, we hold that neither the likelihood of such injury nor the difficulty of proving it is so great as to justify awarding compensatory damages without proof that such injury actually was caused." $I d$. at 264.

A "per diem" methodology is frequently used to compensate prisoners for violation of their constitutional rights. See Madison County Jail Inmates v. Thompson, 773 F.2d 834, 842 ('7th Cir. 1985); O'Connor v. Keller, 510 F. Supp. 1359,1375 (D. Md. 1981) (noting that the plaintiff was awarded $\$ 100$ per day for each day he was confined to an isolation cell in violation of his right not to be subjected to cruel and unusual punishment). 
pain, suffering, and loss of dignity and so refuse to award substantial damages for such injuries in the prison context. ${ }^{401}$

The catalyst's approach to promoting compliance is limited by appellate decisions in some jurisdictions. The Eleventh Circuit, for example, overturned a district court's order releasing inmates because the district court failed to use a contempt sanction first to enforce its order. ${ }^{402}$ Moreover, the use of contempt sanctions to coerce compliance has not been upheld uniformly by the circuit courts. ${ }^{403}$

Most importantly, negative sanctions carry the risk of increasing resistance to the court's intervention. Contempt sanctions may undercut the defendants' willingness to cooperate with the court and heighten their intransigence. Severe sanctions may make heroes or martyrs out of the most uncompromising resisters. ${ }^{404}$ Less vocal opponents of the court's intervention may attempt to minimize the court's impact by complying only to the extent necessary to avoid further contempt sanctions. However, the catalyst's synthesis of negative sanctions with a participatory remedial process reduces the threat of prolonged resistance. In order to avoid further sanctions, defendants must participate in an interactive process that educates them concerning the need for reform and promotes their acceptance of, and commitment to, the new normative agenda. The combination of external pressure and internal process compensates for the limitations of each component of the catalyst approach. Even with these limitations, the catalyst approach offers the greatest potential

401 See, e.g., Madison County Jail Inmates v. Thompson, 773 F.2d 834, 842-43 (7th Cir. 1985) (declining to award class-wide damages to jail inmates for cruel and inhumane punishment where some of the conditions complained of were caused by prisoners); see also L. YACKLE, supra note 51, at 98-99 (relating an instance where a judge was reluctant to award damages).

402 See Newman v. Alabama, 683 F.2d 1312, 1321 (11th Cir. 1982), cert. denied, 460 U.S. 1083 (1983).

403 See, e.g., Newman v. Graddick, 740 F.2d 1513, 1523-24 (11th Cir. 1984) (declining to follow the recommendation of Newman $v$. Alabama regarding the use of contempt sanctions).

404 The public response to the release of inmates may also provide fuel for a political backlash, particularly where there are public officials willing to exploit the situation for political gain. This is what occurred in Alabama, where the Attorney General blamed the federal court and the governor for the release of inmates, and attempted to "capitalize on public anxiety over the release of convicts and thus to increase his political popularity-both affirmatively by resisting the release order in court, and negatively, by suggesting that [the governor] favored the release of felons and contrasting the governor's stance with his own." L. YACKLE, supra note 51, at 202-203 (footnote omitted). 
for introducing incentives that break the prison stasis and enable meaningful compliance.

\section{The Court's Capacity to Foster the Development of an Information- Gathering System}

Prison officials often lack basic information about the nature and limitations of their operations. Information needed to make programmatic improvements typically does not flow to decisionmakers. ${ }^{405}$ As part of the process of monitoring and reporting on compliance with court orders, courts can require the development of a comprehensive information base about current conditions within the prison, ${ }^{406}$ develop information-gathering systems that fill the communication gap, and make valuable information available on a routine basis to decisionmakers. ${ }^{407}$ This information base precludes the use of secrecy to maintain illicit practices and can be used to stimulate and focus reform efforts.

In response to court-ordered reporting requirements, prison administrators must develop a mechanism for gathering information about compliance efforts. ${ }^{408}$ In some prison systems, administrators have created positions devoted to the task of monitoring compliance with court orders. ${ }^{409}$ Other departments have developed and implemented grievance mechanisms and other administrative procedures that enable inmates or guards to bring complaints to the attention of the administration. ${ }^{410}$

Courts often rely on plaintiffs' counsel or court-appointed off-

405 See supra notes 121-32 and accompanying text.

406 See, e.g., Harris v. Pernsley, Order (E.D. Pa. July 13, 1988, paragraph 4(a) (requiring defendants to provide computerized information on detainees); M.K. HaRris \& D. SPILler, supra note 17 , at 18.

407 Court intervention may also stimulate factual investigation by other branches of government. See, e.g., M.K. Harris \& D. SPILLER, supra note 17, at 148 (noting that after the complaint was filed in Holland v. Donelon, No. 71-1442 (E.D. La. May 16, 1972), the grand jury conducted an investigation and issued a report concerning conditions at Jefferson Parish Prison).

408 See, e.g., id. at 18 (describing the types of mechanisms used for monitoring compliance); id. at 206 (concluding that the suit in Holland led defendants to initiate regular reports on the status of jail inmates; these reports could be used to decrease jail population).

409 See supra note 339 and accompanying text.

410 See, e.g., Special Project, supra note 38, at 545-46 (noting that the fear of judicial imposition of court procedures led to improved grievance procedures); $L$. YACKLE, supra note 51, at 253 (detailing how the Commissioner of the Alabama prison system negotiated an agreement with the Implementation Committee under which isolated inmate complaints would be referred to a new grievance system to be established within the prison). 
cials to develop information gathering systems that include interviews, inspections, and document reviews. ${ }^{411}$ Through regular and intensive observation of particular prison practices, masters and monitors are able to gather a more complete and accurate picture of practices than is available from internal sources of information. The development and dissemination of reliable information about prison conditions forces prison officials to acknowledge existing problems and may create public pressure to take corrective action. ${ }^{412}$ The information generating role of the court is often pivotal to breaking the dynamic of prison stasis.

\section{The Deferrer and the Limits of the Reactive Method of Information-Gathering}

The deferrer plays no independent role in structuring the information gathering, reporting, and monitoring functions. The parties and their counsel bear full responsibility for fact-gathering. Thus, the court does nothing to compensate for the absence of accurate and useful information about prison practices or conditions. ${ }^{413}$

Plaintiffs' counsel typically is unable to compensate sufficiently for the prison's inadequate information gathering mechanisms. Once the trial is over, plaintiffs' counsel frequently lack the time, energy, and resources to monitor vigilantly the status of prison conditions and practices. ${ }^{414}$ Moreover, communications between prison

411 See, e.g., M.K. Harris \& D. SPILlER, supra note 17, at 193 (describing how the master in Holland visited the jail twice a week on a surprise basis, inspected the facility, interviewed inmates and staff, and met with the prison administrators and jail managers to discuss his findings and suggestions); id. at 393 (noting that the Collins court relied primarily on the plaintiffs' attorneys for monitoring extent of compliance); L. YACKLE, supra note 51, at 47-48 (describing how Judge Johnson invited the Justice Department to conduct an investigation of the prison involved in the Newman $v$. Alabama litigation).

412 See, e.g., M.K. Harris \& D. Spiller, supra note 17, at 94 (asserting that prison officials eliminated unconstitutional prison conditions once they were brought to light through litigation); Telephone interview with Vincent Nathan, supra note 205, at 30-31 (describing how the court appointed investigators developed factual record that was ultimately accepted as accurate by counsel, prison officials and state leadership, and was followed by a search for solutions to problems reflected by the findings of the special master).

413 See, e.g., M.K. Harris \& D. SpIllER, supra note 17, at 73-74 (noting that the court did not develop a complete record exposing the extent and nature of ongoing brutality and mental harassment). This approach may be attributable to the view that correctional problems do not require expertise and to the desire to minimize the defendants' resentment. See id. at 89-90.

414 See, e.g., id. at 20 (noting the plaintiffs' counsel's efforts to monitor compliance diminished over time); id. at 191-92 (stating that in Holland, the plaintiffs' attorneys" "time and energy for compliance monitoring dwindled over time" and that 
officials and plaintiffs' counsel tend to be adversarial. The prison administration may restrict plaintiffs' counsel's access to the prison, ${ }^{415}$ and is likely to challenge information obtained from plaintiffs' counsel rather than use it to determine whether a corrective response is necessary.

Judicial intervention in and of itself does not create incentives for defendants to develop information. Because the deferrer is not a presence within the prison system, she does not generate the opportunity or incentive to share information with the court. From the prison official's perspective, the less the court knows about prison conditions, the better. Any information that is provided to the court could be used against the prison to justify greater judicial oversight. Line workers and their supervisors have neither the opportunity nor the incentive to provide information to their superiors concerning the inadequacies of the present system. ${ }^{416}$ Information gathered by attorneys for either side is likely to reflect the adversarial nature of formal judicial proceedings and will fail to capture the complexities of the problems and potential solutions. Thus, the deferrer does little to alter the information available to the prison officials, the court, or the public.

\section{The Director and the Hazards of Self-Monitoring}

The director assumes control of the process of gathering information primarily by relying on a court-appointed agent to monitor compliance with the court's order ${ }^{417}$ and by inspecting the prison on a regular basis. This approach greatly enhances the visibility of the court within the prison and enables the court to develop a more accurate picture of the status of compliance efforts. In this way, the

the master stated that the attorneys for the plaintiffs were not very helpful or cooperative during the compliance phase); id. at 396-97 (noting that the limitations on plaintiffs' counsel's "time and energy, combined with the massive nature of the relief ordered, resulted in an inability to maintain the monitoring in the manner desired").

415 See, e.g., id. at 190-91 (describing how in Holland, plaintiffs' attorneys reported that prison officials discouraged and at times denied them access to the prison, and required them to specify particular inmates to visit and provide background materials before each visit).

416 See supra notes 121-30 and accompanying text.

417 The director may set up a procedure resembling a grievance mechanism. For example, in Pugh $v$. Sullivan, Judge Johnson forwarded the inmate letters he received, which asserted complainrs about prison conditions, to the Human Rights Committee for investigation and resolution. See L. YACKLE, supra note 51, at 115-16. 
director overcomes the problems engendered by the deferrer's reliance on the parties to generate information.

The director's role in generating information about the state of the prison system, however, is constrained by the court's implementation activities. Prison officials resisting active judicial oversight will try to limit the court's access to information. To the extent that information gathering is formalized, it is less likely to contain the variety of conflicting perspectives that comprise the prison system.

The director also must evaluate the adequacy of her own conduct or programs. This self-evaluation poses an additional challenge to the legitimacy of the court's role and the reliability of the court's assessment of compliance progress. It is quite difficult to maintain neutrality and the appearance of impartiality under these circumstances. ${ }^{418}$ Yet neutrality and fairness are key to the court's persuasive authority and legitimacy.

The information that is gathered may enhance the court's knowledge of the deficiencies of the existing system, with the possible effect of forcing the prison officials to acknowledge the existence of those deficiencies. ${ }^{419}$ However, information disclosure does little to facilitate the exchange of information within the prison system that often fails to occur in the absence of intervention. By using its own formal and informal processes to gather information, the court essentially absolves the prison officials of the necessity of developing internal monitoring systems that could be used to inform the policymaking process in the future. ${ }^{420}$ The system's capacity to generate the information necessary to self-correct remains unchanged. ${ }^{421}$

418 The difficulty of maintaining neutrality is illustrated by Judge Johnson's $e x$ parte meetings with plaintiffs' counsel to discuss strategy for preserving his orders on appeal. See id. at 42-43.

419 See supra note 412 and accompanying text.

420 In Texas, the master's office, rather than the prison system itself, developed an extensive network of information sources and channels. See B. Crouch \& J. MARQUART, supra note 29, at 130-31. Once the court departs, there is a serious risk that the inadequacies in information exchange that enabled the initial constitutional violations will re-emerge.

421 There is no distinctive approach to information gathering that characterizes the broker. The broker may use any of the approaches described in this section to gather information, which is then used to achieve agreement among the parties concerning the remedy. For this reason, the broker's capacity to improve prisons' information gathering mechanisms is not separately analyzed. 
3. The Catalyst: Information-Gathering as an Integral Part of the Remedial Process

The catalyst combines court-controlled monitoring with the requirement that the prison system develop information systems that educate both the responsible officials and the court about the status of compliance and the possible approaches to improving prison conditions. The information gathering requirement is incorporated into both remedy formulation (and reformulation) and compliance monitoring. The prison officials must present the court with sufficient factual support to justify the particular programs they adopt. Prison officials also must establish internal information systems to satisfy the court's demands for informed decisionmaking and submit regular status reports. ${ }^{422}$ The catalyst may thereby stimulate the adoption of computerization, grievance mechanisms, and reporting systems that provide for regular input from staff and inmates. ${ }^{423}$ Thus, the catalyst provides incentives for those within the prison to develop mechanisms for bridging the information gap among policymakers, supervisors, and line-workers.

The catalyst uses information-gathering requirements to establish its presence within the prison and create pressure toward compliance without assuming direct responsibility for, or control over, the management of the institution. ${ }^{424}$ Because responsibility for implementation remains with prison officials, the catalyst minimizes the conflicts generated by the director's dual role of administrator and enforcer. At the same time, the catalyst may enhance the capacity of the responsible officials to detect and anticipate problems and plan accordingly.

The cooperation and involvement of competent prison officials, of course, is a prerequisite for the development of a constructive problem-solving approach to implementation. Prison officials may resist developing and utilizing information. The catalyst may not require the administration to gather information about aspects of the prison unrelated to the legal violation before the court. To the extent the monitoring process becomes adversarial, the reliability of

422 See Champagne, supra note 283, at 91-92 (noting that in Taylor $v$. Sterrett, the court ordered regular progress reports which led to specific recommendations for remedying jail problems).

423 See supra notes 406-08 and accompanying text (detailing improved information gathering as result of court reporting requirements).

424 See, e.g., M.K. Harris \& D. SpILLER, supra note 17, at 394-95 (concluding that the defendants' obligation to file regular compliance reports in Collins $v$. Schoonfield had the effect of exerting pressure toward compliance). 
the information provided by defendants is likely to decline. Workers may withhold or distort information that they fear may be used to change their routines or increase supervision of their activities. Officials may resist incorporating information gathered by the court, or for litigation, into their overall decisionmaking and planning process. ${ }^{425}$

The catalyst creates both incentives and structures for workers to cooperate in obtaining and providing information, reducing the likelihood of sustained resistance to the court's information gathering function. This enables the catalyst to bridge the information gap that currently exists within many prison systems.

\section{The Court's Capacity to Empower Change Agents Within the Prison}

Members of the prison community who support change often lack political and organizational power. Judicial intervention can tip the balance of power in the direction of change. By acknowledging the constitutional necessity for change, the court enhances the visibility and the legitimacy of the internal reformers. The judicial imprimatur adds leverage to corrections' requests for budgetary increases. ${ }^{426}$ Judicial intervention may enhance public support for prison reform by exposing unconstitutional conditions and practices and legitimizing inmate grievances. ${ }^{427}$ Court-ordered reform may facilitate the growth of new advocacy groups both in the legislature and in the private sector. Prison staff committed to change may have increased access to power. ${ }^{428}$ Judicial intervention thus may compensate for the absence of an effective political constituency for prison reform.

425 The success of the information gathering process may be dependent upon the continuation of the litigation; when the court's active involvement ceases, the newly developed sources of information and planning may disappear. However, the specter of renewed judicial intervention should prison conditions deteriorate dramatically may provide on-going incentive to maintain effective information channels.

426 The prison officials themselves frequently understand and seek to harness their increased leverage as a result of a court mandate. See L. YACKLE, supra note 51, at 92 (asserting that the defendants hoped that the court would order the expenditure of much larger sums of money and that "the new commissioner, Mr. Locke, would be able to take the decree to the legislature and succeed with a judicial order where Sullivan had failed without one." (footnote omitted)).

427 See, e.g., M.K. Harris \& D. SPIller, supra note 17, at 26-27 (noting that prison litigation brought "nightmarish realities to public view," forcing legislators to respond to public concerns).

428 See, e.g., L. YACKLE, supra note 51, at 102 (discussing Judge Johnson's order that new guards be hired in numbers sufficient to adequately staff prison). 


\section{The Deferrer: The Power Dynamic Remains Unchanged}

The deferrer places her symbolic and normative power behind the officials responsible for achieving compliance. Respect for the judiciary and its authoritative pronouncements may increase the reformers' power by legitimizing demands for reform and requests for increased resources. However, the court's normative influence within the prison bureaucracy is limited. ${ }^{429}$ Similarly, many of those outside the prison system do not perceive themselves as responsible or accountable for the conditions within the prison. ${ }^{430}$ The deferrer's strategy fails to generate support for the view that reform is imperative. Politicians may believe that judicial involvement in state executive functions is inappropriate, particularly when such involvement forces the legislature to appropriate public funds for prison reform. Media coverage and the resulting public pressure for reform often diminishes when the liability stage of the litigation ends.

The deferrer does not buttress her normative authority by employing the power of the state to enforce its mandate. ${ }^{431}$ The court instead relies on the limited power of the formal defendants to mobilize necessary support for particular programs. Guards and inmates can effectively resist reforms that require a change in their routines and practices, and have incentives to do so. ${ }^{432}$ Legislators ignore requests for additional expenditures. ${ }^{433}$ Criminal justice agencies can refuse to participate in efforts to coordinate policy to reduce prison population. ${ }^{43.4}$ Governors can withhold political and budgetary support for change. ${ }^{435}$ The deferrer does little to increase the leverage of those seeking change within the prison system or to protect them from the political consequences of their actions.

Because the deferrers' intervention is hortatory and symbolic, participants in the prison dynamic understand that there is no realistic likelihood of a direct confrontation with the court. Not surprisingly, they frequently remain opposed to reform and continue to engage in behavior that frustrates the director's compliance

429 See supra notes 259-260 and accompanying text.

430 See supra note 153 and accompanying text.

431 See, e.g., M.K. Harris \& D. SPIller, supra note 17, at 105 (noting that "[t]here was a conspicuous absence of enforcement mechanisms throughout most of the Holt $v$. Sarver litigation").

432 See supra notes $134-43$ and accompanying text.

433 See supra notes $147-49$ and accompanying text.

434 See supra notes 150-52 and accompanying text.

435 See supra notes $109-11$ and accompanying text. 
efforts. ${ }^{436}$ The same factors that limit the capacity of prison officials to improve prison conditions in the absence of judicial intervention disable them from unilaterally eliminating these conditions. By relying exclusively on the defendants to remedy unconstitutional prison conditions, the court incorporates these limitations into the remedial process. In many cases, the deferrer simply avoids meaningful change necessary to eliminate unconstitutional conditions. ${ }^{437}$

\section{The Director and the Limits of the Court's Administrative Power}

The director attempts to use her power to assume control over implementation to achieve compliance directly. ${ }^{438}$ The director's information-gathering activities may bring about public exposure that generates political support for court-ordered change. This may shift the power balance, at least temporarily, in the direction of change. ${ }^{439}$ If the director is able to increase prison resources and staff, these new influences may shift the power balance and enable some reform. The director may implement programmatic changes that do not require substantial cooperation or additional legislative support and can be easily monitored.40 Thus, the director may accomplish discrete reforms that prison administrators may be unable or unwilling to pursue due to the political pressure to maintain the status quo.

However, the court, by assuming the director role, directly confronts the existing power structure of the prison system. In some respects, the director steps into the shoes of the administrator, with greater visibility, less political vulnerability, less flexibility, and sub-

436 See, e.g., L. YACKLE, supra note 51, at 225-26 (describing how the momentum of the Alabama litigation was lost and how the Governor became less willing to cooperate with the court after the Court of Appeals limited the trial court's authority to release inmates or hold state executive authorities in contempt).

437 This does not mean that deference is never an appropriate judicial strategy. Once the prison dynamic is broken, either through judicial intervention or political response, and defendants have developed effective internal systems of monitoring and self-correction, deference may be appropriate to reward defendants' compliance progress and encourage the maintenance of internal mechanisms for change.

438 See supra notes 204-18 and accompanying text.

439 See, e.g., M.K. Harris \& D. SpIller, supra note 17, at 166-67 (noting that court intervention provided the impetus for the establishment of a medical care program with Tulane University that was far superior to prior arrangements, and went beyond what was required by a court order then in effect).

440 See, e.g., id. at 367 (noting that in Collins v. Schoonfield, 344 F. Supp. 257 (D. Md. 1972), the court ordered strict limitations on the use of strip cells, leading defendants to abandon them and weld their doors shut). 
stantial controversy over the court's role. By attempting to exercise power directly, the court may solidify positions opposed to change and polarize the competing interests within the prison. The court's influence over those operating within the prison is limited. ${ }^{441}$ The same factors that limit the prison administrator's power over the internal hierarchy constrain the court's power to alter patterns and practices within the prison. The perceived illegitimacy of the court's administrative role limits its managerial power.

The director faces additional limitations stemming from its limited mandate. The court cannot assume complete administrative responsibility. It may only intervene to the extent necessary to respond to particular constitutional violations. The broader managerial strategies that could enhance the court's capacity to institutionalize its reform agenda may not be adopted because they are beyond the director's mandate. ${ }^{442}$

The director's power to affect the conduct of external actors also is limited. The court has no direct control over outsiders whose participation is necessary for compliance. Although the court can generate public pressure for change, the controversy over the court's role in the prison may deflect public concern about the prison conditions and diminish the possibility that political pressure will force state officials to institute reforms. Outsiders may be unwilling to cooperate with the court out of fear that this would somehow legitimize the court's directorial role and encourage increased court activity. ${ }^{\mathbf{4 4 3}}$ There are substantial incentives to resist the director's overtures, because the court appears unable or unwilling to impose any sanctions in the face of noncompliance and may in fact back down in the face of continued noncooperation. ${ }^{444}$

Thus, the court's power to achieve compliance directly is limited when employing the director approach. The question remains whether the director can empower the participants in the prison dynamic to implement change. The director, by mandating and undertaking reform on behalf of inmates, gives visibility and legitimacy to inmates' concerns. The court's activist intervention encourages inmates to use the court to enhance their conditions, status, and power within the prison. Inmates may rely on their access to the

441 See supra notes 281-92 and accompanying text.

442 See supra notes 303-12 and accompanying text.

443 Cf. L. YACKLE, supra note .51 , at 89 (noting that Judge Johnson refused to involve the parole board in the litigation, and that the board "never assisted significantly in the drive to reduce Alabama's prisoner population").

444 See supra note $367-70$ and accompanying text. 
court, rather than their capacity for disruption and violence, as a means of pursuing their concerns about prison conditions if the court is perceived as an effective advocate of their interests.

As the director assumes direct responsibility for implementation, there is a tendency to limit direct contact with inmates and to define the court's goals in terms of limited objectives, rather than inmates' interests. The court compromises to stay within the scope of its authority and achieve compliance. If inmates begin to identify the court with the administration and to perceive a divergence of interests, they may withdraw cooperation and support, and pursue their interests in other ways.

The director may also enhance the guards' power by reinforcing the importance of the security function and increasing the number of guards employed. However, the director does not alter guards' access to decisionmakers or their capacity to exercise control over their day-to-day working conditions. ${ }^{445}$ Many of the court's actions threaten to limit guards' autonomy in their management of inmates. By bringing in resources and staff to pursue noncustodial goals, the director may further threaten the guards' status and autonomy. Guards are predisposed to perceive the director as an adversary whose power must be contained. They are likely to engage in a dynamic similar to their interaction with a reform administrator. ${ }^{446}$ Guards retain the power of withdrawal, resistance, and disruption. They can neutralize court-ordered reforms by tailoring them to the existing routine. They can try to divert attention from court-ordered reforms to security concerns that are likely to take precedence in the face of threatened disruption of order. ${ }^{447}$ The court has limited power to prevent or control this conduct.

The director's impact on the transformative potential of counselors and staff is also likely to be problematic. True, the director may increase the status and numbers of counselors by underscoring the importance of the counselor's function, establishing particular programs, and bringing in people who are sympathetic to the counselor's perspective. The director, however, has little or no effect on the counselor's role in the prison's decisionmaking processes.

445 The director partially could overcome this limitation by requiring the prison administration to set up structures that give guards access to the director, such as grievance systems or regular training programs. Unfortunately, these types of orders have been reversed by Courts of Appeals for exceeding the scope of the court's authority. See Hoptowit v. Ray, 682 F.2d 1237, 1250-51 (9th Cir. 1982).

446 See supra note 43 and accompanying text.

447 See supra note 137 and accompanying text. 
Counselors remain peripheral to the primary goal of the institution-the maintenance of order. They continue to depend on the guards for movement within the prison, information, and latitude to perform their noncustodial duties. Indeed, the perception that counselors and the court share an identity of interests polarizes the counselors relationships with others within the prison. As a result, counselors encounter increased resistance to their participation in the management of the prision.

Finally, the director is unlikely to have a significant effect on the capacity of the prison administration to bring about change. The prison administration remains stymied by the lack of structures for obtaining reliable information about prison conditions, the limited extent to which it can influence the conduct of the guards and counselors, and the absence of political and financial support for prison reform. ${ }^{448}$ In the absence of any direct costs, political or financial, stemming from resistance, outside politicians are likely to use the prison controversy for their own political ends and to resist prison officials' reform efforts. ${ }^{449}$ If the administration is perceived as an ally of the court, its capacity' to influence either its internal or external constituencies may be further diminished. ${ }^{450}$

Thus, if the courts respond to defendants' failure to eliminate unconstitutional conditions by assuming direct managerial control over implementation, they are unlikely to empower those individuals critical to altering the dynamics of organizational stasis. Although the director approach may accomplish discrete programmatic reforms, it is likely to fail as a general approach to resolving the dilemma, and may have regressive effects on the development of more creative, systemic approaches to the problems facing prisons.

\section{The Broker: Variations on the Theme of Deference}

The broker essentially remains outside the power dynamic of the prison system. Because of its heavy reliance on lawyers to negotiate and communicate with the court concerning compliance, the prison participants remain essentially unaffected by the negotiation

448 See supra notes 133-56 anc. accompanying text.

449 See, e.g., L. YACKLE, supra note 51, at 125-26 (discussing the tactics used by Alabama's Governor and Lieutenant Governor to turn the prison controversy to their political advantage, with little or no effect on actual prison conditions).

450 See, e.g., Giari, supra note 59, at 461 (noting that Oklahoma legislators forced the resignation of a director of corrections when he was perceived to be sympathetic to court intervention). 
process. ${ }^{451}$ The broker's exclusive reliance on agreement and renegotiation, even in the face of continued noncompliance, undercuts the potential pressure that the court could bring to bear to change the power dynamics supporting the status quo. Thus, although the broker may achieve agreements to undertake change, it does not generate the public pressure, visibility and leverage necessary to enable responsible officials within the prison system to carry out those agreements.

\section{The Catalyst: Empowerment Through Participation and} Pressure

The catalyst attempts to use its power to create processes that effectively confront unconstitutional prison conditions. The catalyst augments the potential influence of its normative authority with the power generated by employing traditional judicial authority to impose sanctions and award compensation. This approach also uses judicial power to structure a remedial process that has the potential to empower participants to undertake change by enhancing their knowledge and access to those whose cooperation is necessary to achieve compliance.

The public pressure imposed on prison and state officials through the exposure of prison conditions and the imposition of costs for noncompliance creates a new source of power for those usually stymied by the absence of executive and legislative support for reform. The options of invisibility and avoidance of disruption, ordinarily chosen by many prison officials and politicians, are eliminated. In fact, under the catalyst's regime, the only way to reduce or eliminate judicially created costs is through reform. Because these costs affect actors outside the prison system, the catalyst may empower the prison officials to enlist the cooperation of the governor, the legislature, the parole board, and other government actors whose conduct directly bears on prison conditions. This new-found support may then empower reformers to withstand the internal disruption and resistance that limits their capacity to implement change.

The catalyst, of course, will not always successfully create a dynamic that empowers meaningful change. Public officials are sometimes willing to incur huge political and financial costs simply to

451 But see supra note 373 (describing the capacity of lawyers to compensate for some of the limitations of the broker by building into their agreement provisions for altering the power dynamic). 
stand up to the court. If the defendants continue to resist in the face of sanctions, the catalyst is forced to choose between the Scylla of the deferrer and the Charybdis of the director. Particularly where the ongoing violations subject inmates to imminent and permanent injury, the constitutional duty to remedy ongoing violations warrants assumption of the director role to accomplish discrete programmatic reforms, even though this approach is unlikely to alter the dynamic of organizational stasis. Even the most intransigent officials may reach a limit in terms of their perception of costs the public will tolerate in the name of political autonomy. Moreover, during the period of resistance, inmates receive compensation for the ongoing injury caused by the defendants' resistance, and some may be released if the conditions are sufficiently severe to justify this remedy. These measures also have the effect of increasing the pressure on resistant officials to undertake institutional self-correction. Thus, the catalyst creates processes, opportunities and pressures that can empower those within the prison system, particularly the prison administration, to undertake meaningful reform.

\section{ConClusion}

The current state of prisons represents one of the enduring failures of our social institutions. Certainly, court intervention will not eradicate the deeper, more fundamental problems that are endemic to the current institutional structure. Any court intervention is ultimately limited by the existing institutional and political structure, the court's limited mandate, and the profound difficulty of achieving bureaucratic reform. At best, effective judicial intervention can alleviate the most immediate and profound suffering perpetuated by the dynamics of organizational stasis and foster the development of more humane and sophisticated approaches to corrections.

However, given the dynamics of organizational stasis, in many prisons change is unlikely to be undertaken in the absence of judicial intervention. This Article has shown that the court has the potential to influence this dynamic in the direction of reform, but that the court's capacity to resolve the dilemma will depend, at least in part, on the approach adopted by the court to manage the compliance process. Courts inevitably choose managerial strategies in overseeing the compliance process, and those choices govern the extent to which the court is likely to influence the norms, incentives, information sharing, and power structure of the prison system in ways that tend to bring about meaningful change. 
By adopting a strategy that capitalizes on the strengths of the court's traditional judicial power, the catalyst approach has real potential to address the dynamics of organizational stasis that lock in unconstitutional prison conditions, and yet remain within the boundaries of the judicial role. Given the superiority of the catalyst approach as a means of resolving the dilemma, steps should be taken to promote its adoption by trial courts faced with the task of managing the compliance process. The doctrinal barriers to the catalyst's capacity to use incentives to bring about change should be reduced or eliminated. Trial courts should be afforded substantial discretion in using contempt and release orders as a response to non-compliance. Inmates should be permitted to recover damages as compensation for continued noncompliance, despite the frequent intangible nature of their injuries.

Perhaps more importantly, it is imperative that courts recognize that effective use of their traditional judicial powers can maximize their capacity to promote institutional self-correction and preserve the judicial character of their intervention. Mechanisms for sharing ideas and information among trial judges concerning their role and increasing their awareness of the strategic choices and their consequences must be developed. This may require using judicial conferences, the Federal Judicial Center's resources, and other means beyond the formal judicial opinion, which does not ordinarily perform this educative function with respect to the trial court's managerial strategy.

Appellate courts also play a pivotal role in determining how trial courts manage the remedial process and how they allocate power and responsibility for achieving compliance. Appellate courts must recognize and accept the dynamic, managerial role the lower courts play in the implementation process, and create incentives through the review process for trial judges to adopt the catalyst approach. ${ }^{452}$

The four approaches analyzed above provide a starting point for future inquiry into effective strategies for judicial intervention. One fruitful area of inquiry is the extent to which the nature of the violation at issue influences the effectiveness of a particular judicial approach. For example, it has already been pointed out that the director approach may be particularly effective in introducing discrete changes in practices or conditions that do not require systemic cooperation or changes in basic routine, such as the abolition of a

452 The role of appellate courts in institutional reform litigation is the subject of a forthcoming article. 
particular type of punishment or a one-time change in the physical facilities. ${ }^{453}$ Effective redress of other types of prison problems, such as violence, arbitrary disciplinary practices, and other problems involving changes in daily routines or inmate guard relations will likely require the catalyst approach. The catalyst can also prompt a systemic response to overcrowding-perhaps the most pressing issue facing prisons today. ${ }^{454} \mathrm{~A}$ combination of judicial approaches may be warranted if a particular litigation involves both discrete and systemic issues.

Finally, it is worthwhile to explore the implications of the contextual and strategic approach to remedies set forth in this Article for other areas of institutional reform. There may be other judicial approaches that characterize intervention in other contexts and are likely to be effective in generating change in that particular institution. Political and institutional variables, such as the existence of a statutory mandate, the degree of centralization and bureaucratization of the institutions at issue, the level of consensus about the legal norm, the level of expertise required to address the issue, the capacity and political strength of the interested parties and the degree of public access to the institutions at issue will influence the analysis of the relative effectiveness of each judicial approach. This type of institutional analysis may also be useful in considering the relative effectiveness of nonjudicial interventions, such as legislative and administrative programs designed to achieve change.

By examining the dynamics underlying a particular institution's failure to comply with the law, we can better understand the extent to which the court can effectively intervene. With this greater understanding of their potential and limits, judges will be better situated to resolve the remedial dilemma by adopting a judicial strategy that fosters institutional self-correction.

453 See supra note 293 and accompanying text.

454 Prison officials and line workers are likely to support any court activity designed to reduce overcrowding because it does not disrupt their routine and makes their jobs easier and safer. Indeed, some guard unions have filed law suits challenging the legality of overcrowded prisons. See, e.g., Fennell, Islands of Violence: The Crisis of America's Prisons and Jails, 8 J. of Soc., Pol. \& Econ. STud. 81,89 (1983) (acknowledging that "corrections officials sometimes welcome . . . court orders that force public spending for sorely needed renovations or even new . . . prisons," but view expanding the sphere of inmates' rights as counterproductive). 